\title{
Bacterial wilt of cucurbits: Ecology, genetics, and management
}

\author{
by
}

\section{Erika Saalau Rojas}

\author{
A dissertation submitted to the graduate faculty \\ in partial fulfillment of the requirements for the degree of \\ DOCTOR OF PHILOSOPHY
Major: Plant Pathology
Program of Study Committee:
Mark L. Gleason, Major Professor
Gwyn A. Beattie
Larry J. Halverson
Gail C. Nonnecke
Matthew O’Neal
Iowa State University
Ames, Iowa
2013

Copyright (C) Erika Saalau Rojas, 2013. All rights reserved. 
TABLE OF CONTENTS

Page

ACKNOWLEDGEMENTS .................................................................... iv

ABSTRACT ............................................................................................... V

CHAPTER 1. GENERAL INTRODUCTION ................................................... 1

Dissertation organization................................................................................ 1

Literature review ……….............................................................. 2

Research Justification................................................................................... 22

Literature cited ................................................................................. 24

CHAPTER 2. FEASIBILITY OF DELAYING REMOVAL OF ROW COVERS TO SUPPRESS BACTERIAL WILT OF MUSKMELON

(CUCUMIS MELO L.) ............................................................................... 36

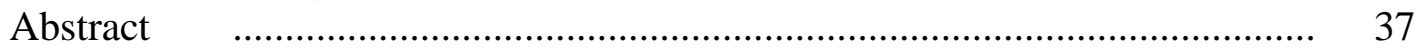

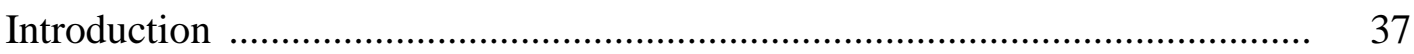

Materials and Methods ............................................................................... 38

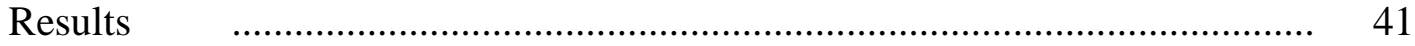

Discussion .................................................................................................. 43

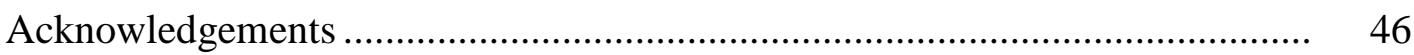

Literature Cited ....................................................................................... 4

Tables $\quad$..................................................................................... 52

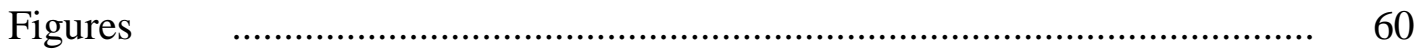

CHAPTER 3. EPIPHYTIC SURVIVAL OF ERWINIA TRACHEIPHILA ON MUSKMELON (CUCUMIS MELO L.) 61

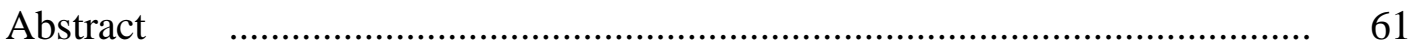

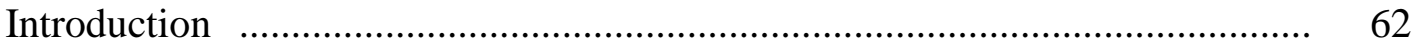

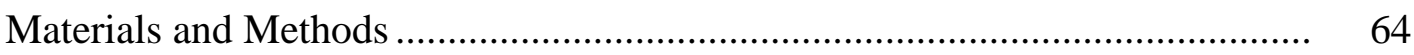

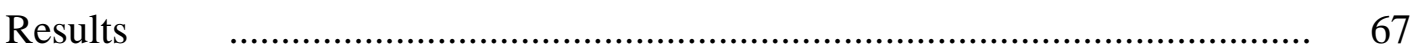

Discussion ………................................................................................. 69

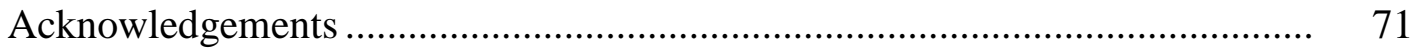

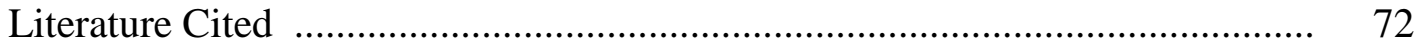

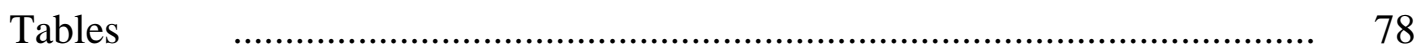

Figures $\quad$........................................................................................ 82

CHAPTER 4. GENETIC AND VIRULENCE VARIABILITY

AMONG ERWINIA TRACHEIPHILA STRAINS RECOVERED FROM

DIFFERENT CUCURBIT HOSTS $\quad 84$

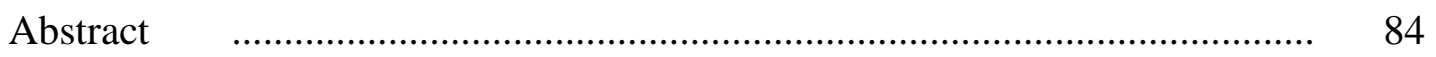




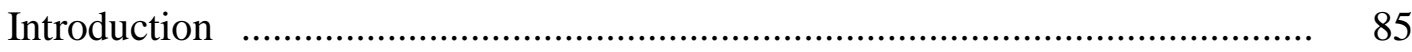

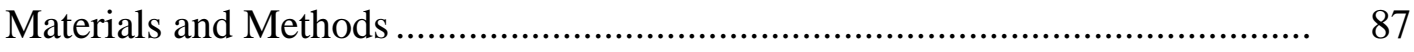

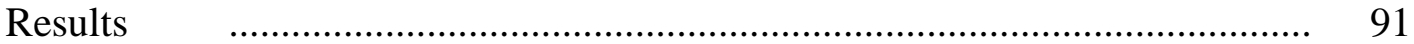

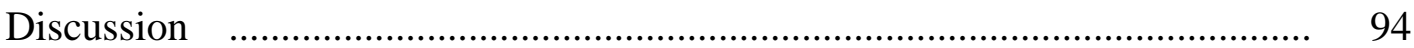

Acknowledgements ............................................................................. 97

Literature Cited ................................................................................... 98

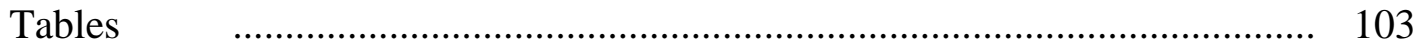

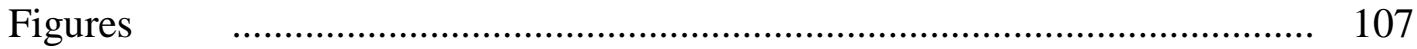

CHAPTER 5. BEES, BEETLES, AND BACTERIA: THE CUCURBIT

BACTERIAL WILT DILEMMA. AN EDUCATIONAL RESOURCE

FOR UNDERGRADUATE EDUCATION 110

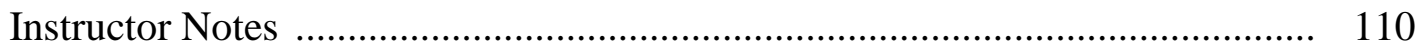

Case Study Part A .................................................................................. 115

Case Study Part B................................................................................ 118

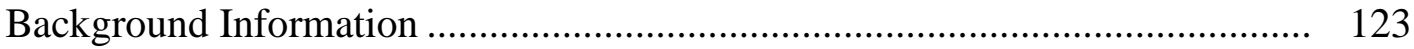

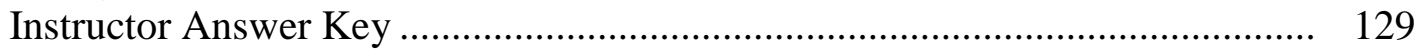

References .................................................................................... 137

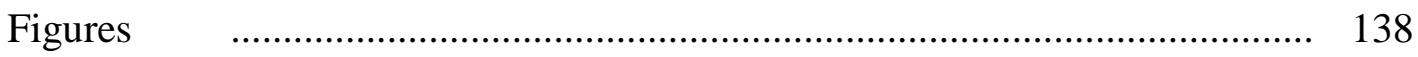

CHAPTER 6. GENERAL CONCLUSIONS ............................................. 145 


\section{ACKNOWLEDGEMENTS}

I would like to thank my committee chair, Mark L. Gleason, and my committee members, Gwyn Beattie, Larry Halverson, Gail Nonnecke, and Matt O’Neal for their guidance and support throughout the course of this research. I especially want to thank Dr. Gleason for his unrelenting encouragement and advice which allowed me to become a better version of myself. In addition, I'm grateful for Jean C. Batzer's help in establishing the field trials and developing several of the laboratory methods I used. I would also like to acknowledge all the members of the Gleason lab (2008-2013) who participated in one or more of the research objectives presented in this dissertation, including field crew members, grad students, and lab members. During this time, I was fortunate enough to find co-workers who also became true friends, especially Alicia Owens, Ximena Cibils, and Michele Hall. The completion of my degree wouldn’t have been possible without the continuous support of Laura Jesse and Daren Mueller; I will always be grateful to them for giving me the opportunity to grow personally and professionally as part of the IPM team. I'd like to thank Déborah Rojas, a teacher and role model, who taught me the skills necessary to persevere and succeed my family members, and my chosen family: Mike Dunbar, José Pablo Soto, Mercedes Arias, and Winnie Gleason. 


\begin{abstract}
Bacterial wilt of cucurbits is an economically important disease that impacts most Cucurbitaceae species. The pathogen, Erwinia tracheiphila, is a vascularinhabiting bacterium overwintered and transmitted by cucumber beetles. Disease management relies on controlling cucumber beetles, mainly through insecticide applications. However, the ecology and biology of E. tracheiphila are poorly understood. A better understanding of this pathosystem is critical for the development of effective and less insecticide-intensive management strategies.
\end{abstract}

Six field experiments were carried out to accomplish the following objectives: 1) assess efficacy of delayed removal of spunbond row covers for suppressing bacterial wilt on muskmelon, and 2) compare costs and returns of row cover treatments. Delayed removal of row covers significantly decreased bacterial wilt incidence. The economic analysis indicated that when bacterial wilt was present, average annual returns were much higher for the delayed-removal strategies than the controls. In the absence of disease, all row cover treatments were less profitable.

Growth chamber and laboratory experiments were conducted with the following objectives: 3) evaluate E. tracheiphila survival on muskmelon leaves under different environmental conditions, and 4) investigate the genetic diversity of E. tracheiphila strains. Growth chamber experiments consisted of spray-inoculated muskmelon seedlings incubated at different temperature and moisture regimes. Survival of $E$. tracheiphila on muskmelon leaves depended on temperature, and presence of leaf 
wetness significantly impacted survival. Results demonstrate that epiphytic populations might serve as a reservoir of inoculum for infections. Genetic variability of $69 \mathrm{E}$. tracheiphila strains was investigated by rep-PCR. Fingerprint profiles were associated with host-plant genus. Cross-inoculation of 12 different strains onto cucurbit seedlings demonstrated that fingerprint profiles were consistent with pathogenicity. Wilting occurred significantly faster when seedlings were inoculated with strains that originated from the same crop host genus. My results provide the first evidence of genetic diversity within E. tracheiphila and suggest that strain specificity is associated with plant host. Finally, a pedagological research objective was the development of a case study to challenge students to solve a disease management situation in the context of real world decision-making. The case was run live with students and instructors, who provided feedback that was integrated into the manuscript. 


\section{CHAPTER 1 \\ GENERAL INTRODUCTION \\ Dissertation organization}

This dissertation is organized in six chapters. The first chapter contains the introduction, literature review, and research justification. Chapter two includes field experiments conducted to determine the efficacy of row covers against bacterial wilt in muskmelon. Chapter three consists of growth chamber experiments to assess the impact of temperature and moisture conditions on epiphytic survival of the causal agent of bacterial wilt, Erwinia tracheiphila, on muskmelon leaves. Chapter four describes laboratory and growth chamber experiments designed to explore the genetic diversity among E. tracheiphila strains and describe their pathogenicity on different cucurbit hosts. Chapter five presents an educational resource developed for undergraduate-level courses in which the bacterial wilt pathosystem is used as an example to explain basic plant pathology concepts and integrated pest management approaches. Finally, chapter 6 presents general conclusions of this project. 


\section{Literature review}

\section{Bacterial wilt of cucurbits: Resurrecting a classic pathosystem}

Manuscript to be submitted to Plant Disease for consideration as a Feature Article

Erika Saalau Rojas, Jean C. Batzer, Gwyn A. Beattie, Shelby J. Fleischer, Lori R. Shapiro, Mark A. Williams, Ricardo Bessin, Benjamin D. Bruton, Margaret T. McGrath, Ruth V. Hazzard, T. Jude Boucher, Laura C. H. Jesse, and Mark L. Gleason

\section{BACKGROUND}

Erwinia tracheiphila, the causal agent of bacterial wilt of cucurbits, was one of the first bacterial plant pathogens ever described (80). In Michigan, U.S.A., in 1893, pioneering plant pathologist Erwin F. Smith witnessed 'entire fields of cucumbers, cantaloupes, and of winter squashes' destroyed by the disease. More than 120 years later, bacterial wilt still menaces many cucurbit crops, causing yield losses up to 75\% (45). Smith’s belief that striped and spotted cucumber beetles (Acalymma vittatum (Fabricius) and Diabrotica undecimpunctata howardi Barber, respectively) were vectors of E. tracheiphila was soon confirmed by Rand and Enlows (67). Rand and colleagues also indicated that bacteria could overwinter inside adult striped cucumber beetles (striped CB), which are believed to be the most important vectors (5, 23, 36, 65).

After this initial flush of discovery, scientific knowledge of E. tracheiphila and bacterial wilt advanced very little for nearly 80 years, in part, because the pathogen is challenging to isolate and maintain in culture. However, a new wave of research progress has gathered 
momentum for the past two decades, yielding many new insights into bacterial wilt ecology, genetics, etiology, and management.

Despite the economic importance of bacterial wilt and its long history in plant pathology research, no review of the pathosystem has been published. The goals of this article are to provide an overview of the bacterial wilt pathosystem, to integrate current and historical information about the host, vectors, and pathogen, and to highlight research areas that appear especially promising.

\section{IMPACT, SYMPTOMS, SIGNS, AND ETIOLOGY}

In the eastern half of the U.S., cucurbit production exceeds 68,000 hectares, representing approximately $68 \%$ of the total cucurbit-crop acreage in the nation (NASS, 2007). In the Midwest, Mid-Atlantic, and Northeast United States, bacterial wilt is regarded as a major threat to cucurbit production. It affects most species within Cucurbitaceae, including economically important crops such as cucumber (Cucumis sativus L.), melon (Cucumis melo L.), squash (Cucurbita maxima, Cucurbita moschata, Cucurbita pepo), and pumpkin (C. pepo) (50, 66, 78, 80, 89, 92). Interestingly, the disease is rare or unknown outside of this geographic region.

Management of bacterial wilt relies primarily on insecticide applications targeting cucumber beetles. Feeding damage alone can significantly impact plant stand and yield in commercial cucurbit plantings (39), but the threat of bacterial wilt transmission makes cucumber beetles the target of most insecticide applications in the high-risk regions (15). Unfortunately, commercially acceptable disease-resistant cultivars are nearly non-existent, so cucumber beetle management is the mainstay of bacterial wilt management programs.

E. tracheiphila is a vascular pathogen. Transmission occurs when beetles feed on plants and deposit bacteria-infested frass onto fresh feeding wounds (46). Once inside the vascular 
system, bacteria multiply and obstruct xylem vessels. Bacterial wilt takes its name from the characteristic wilting of leaves and stems which is usually followed by necrosis and total plant collapse.

Smith noted that bacterial wilt symptoms begin in leaf areas with visible cucumber beetle damage or where the bacterium is puncture-inoculated (80). He described a darker green area that develops around the wounds, with the entire plant eventually changing from a light to dull green color. Affected leaves become flaccid, followed by stem and vine wilting. Initial wilt symptoms occur from 4 to $>21$ days after infection (51). With the exception of watermelon (Citrullus lanatus) and some Cucurbita species (i.e., C. pepo), infected plants rarely recover or yield marketable fruit.

Bacterial wilt diagnosis can be confirmed by direct observation of disease signs in the field, or by the visibility of bacterial slime strands when cut ends of wilting stems are slowly pulled apart (44).

Symptom development varies with plant species, cultivar, and age. Among commercially important crops, cucumber and cantaloupe are highly susceptible to bacterial wilt. Although bacterial wilt can cause devastating losses in commercial pumpkin plantings (B. Bruton, personal communication), Cucurbita species are generally less susceptible than Cucumis species. During Smith's early work (80), inoculation of squash varieties often resulted in inconsistent disease in contrast to inoculation of highly susceptible cucumber and muskmelon, which resulted in disease 'with certainty and regularity of clock-work'. The impact of plant age on susceptibility is gradually becoming clear. Bacterial wilt incidence on pumpkin seedlings artificially inoculated with E. tracheiphila was lower for plants that were at a later plant growth stage at the time of infection (9). In that study, young seedlings generally developed wilt symptoms rapidly. 
Pumpkin plants inoculated during later growth stages (i.e., during the first and second true leaf stage) initially showed symptoms but recovered within several weeks. A comprehensive survey of 59 cucurbit species inoculated with E. tracheiphila showed results similar to those reported on pumpkin: after artificial inoculation at the first-true leaf stage, 14 watermelon cultivars showed bacterial wilt symptoms (89). In contrast, plants inoculated at the 10-leaf stage were tolerant of the disease. Experiments on muskmelon by Liu et al. (2013 APS abstract) demonstrated that symptoms progressed more rapidly following inoculation of seedlings that were 2 weeks old than 6- or 8-weeks old.

\section{HOST RANGE}

Bacterial wilt afflicts many species in the family Cucurbitaceae. Cucumber and muskmelon are highly susceptible, squash and pumpkin are intermediate, and watermelon is apparently highly resistant $(9,92)$. It is uncertain whether watermelon is a host of $E$. tracheiphila; natural occurrence of the disease has only been reported anecdotally until recently (74). Interestingly, bacterial wilt was recently confirmed on watermelon in two commercial farm fields in New Mexico (74), which is well outside the previously established geographic range of the disease.

In addition to commercially important cucurbit crops, bacterial wilt also occurs naturally in wild cucurbit species $(66,75)$. Inoculations performed more than a century ago by Smith (80) confirmed that wild cucurbits including buffalo gourd (Cucurbita foetidissima), coyote gourd (C. californica), bur-cucumber (Sicyos angulatus), and wild cucumber (Echynocystis lobata)

produced bacterial wilt symptoms. These results were confirmed later by Watterson et al. (89) in a study evaluating the susceptibility of cultivated and non-cultivated cucurbits to E. tracheiphila. 
Many key details of bacterial wilt etiology remain unclear. Although weeds in the Cucurbitaceae family have been presumed to serve as reservoirs of E. tracheiphila inoculum that could be transmitted to crop fields (50), there is no clear evidence that alternate hosts outside Cucurbitaceae could serve as inoculum sources. Serological assays suggested the presence of $E$. tracheiphila in non-cucurbit herbaceous weed species, but results were inconsistent and the researchers were unable to re-isolate the pathogen from any of the weeds investigated (50).

\section{PATHOGEN BIOLOGY}

E. tracheiphila is a Gram-negative, facultatively anaerobic, xylem-inhabiting bacterium. Smith noted the difficulty of isolating and working with this pathogen since it grows slowly in culture and is easily overgrown by other microorganisms (80). Unlike most Erwinia species, E. tracheiphila can be challenging to isolate from macerated plant tissues. However, consistent isolation can be accomplished by surface-sterilizing stem and petiole segments and directly plating bacterial masses or ooze exuded near vascular elements $(33,80)$. In the absence of noticeable ooze, exposed vascular tissues in stem segments can be dabbed directly onto solid culture medium (Saalau Rojas, unpublished data).

In culture E. tracheiphila colonies are generally small, circular, viscous, and hyaline or white in color (14). Colony growth on nutrient agar (NA) or nutrient agar plus peptone (NAP) can be observed 3 to 4 days after streaking $(33,50)$.The optimal temperature range for colony growth was between 25 and $30^{\circ} \mathrm{C}$ (33).

With the exception of fatty acid analysis, experiments assessing nutritional requirements and carbon utilization profiles have yielded inconsistent or incomplete results among $E$. tracheiphila strains $(37,84,91)$. A possible explanation for this high level of variability in these studies may be inclusion of only a few E. tracheiphila strains (33,37). Consequently, 
characterization of E. tracheiphila based solely on phenotypic and biological characters should be viewed as preliminary and additional methods (e.g., molecular techniques or fatty acid profiles) are needed to confirm identity.

Pathogenesis. In 1899, microscopic observations on artificially inoculated plants led Smith to believe that mechanical plugging of xylem vessels by E. tracheiphila cells, rather than enzymatic reactions, interfered with water conductance and incited wilting $(51,88)$. There is no evidence for production of hydrolytic or pectolytic enzymes by E. tracheiphila, and in vivo assays suggested that physical pressure due to rapid bacterial multiplication and direct blockage of vessels is the main mechanism for xylem deterioration and wilting (51).

Tissue analysis from less susceptible cucurbits such as cucumber cv. SMR18, watermelon, and pumpkin that either recovered from wilting or displayed partial wilting indicated that E. tracheiphila can be isolated from asymptomatic stems up to 10 days after inoculation (89). Bacteria-host interactions have not been clarified, but qualitative observations suggest that pathogen populations are relatively low in less susceptible hosts (88). In addition, host susceptibility may be impacted by xylem $\mathrm{pH}$ or nutritional conditions within the xylem (51, 90).

Genetic diversity and virulence. Placement of E. tracheiphila within Erwinia has remained consistent since the initial description of the pathogen. Despite phenotypic variation among strains, 16S rDNA sequence-based phylogenetic positioning of E. tracheiphila showed a 95.5\% similarity with Erwinia species and hybridization assays showed 23\% DNA relatedness with Erwinia amylovora $(7,37)$. Moreover, comparison of $16 \mathrm{~S}$ rDNA sequence data of six $E$. tracheiphila strains isolated from different cucurbit crop hosts and geographic regions revealed a difference of only one base pair among strains (Saalau Rojas, unpublished data). Although 
Smith's (80) work suggested that 'particular' E. tracheiphila strains in their virulence in a hostdependent manner when cross-inoculated onto different plant hosts, no pathovars or subspecies of E. tracheiphila have been reported.

Smith noted that strains isolated from muskmelon were virulent on muskmelon and cucumber plants but not on squash (80). Interestingly, recent data appear to confirm these early suspicions about the existence of at least two different E. tracheiphila subgroups. Rep-PCR assays of 69 E. tracheiphila strains from 8 U.S. states revealed that Cucumis and Cucurbitaderived strains generated distinct fingerprint profiles (71). Consistent with Smith's observations, pathogenicity assay results using strains derived from Cucumis and Cucurbita crops species indicated that E. tracheiphila readily induced wilt symptoms when inoculated onto hosts within the same genus from which strains were isolated, but not when cross-inoculated onto the other host genus (71). It therefore appears likely that E. tracheiphila encompasses subspecies or pathovars that are specific to distinct host genera.

\section{PATHOGEN, VECTOR, AND HOST INTERACTIONS}

Striped and spotted cucumber beetles are the only known vectors of E. tracheiphila. In caged trials, squash bugs (Anasa tristis), aphids (Aphis gossypii), squash lady beetles (Epilachna borealis), potato flea beetles (Epitrix cucumeris), and bees (Apis mellifera) were unable to transmit the disease (66). In general, research on disease epidemiology and bacterium-vector interactions has focused on the life cycle and behavior of striped CBs, in part, because it is the only known vector in the eastern part of the geographic range of bacterial wilt. Although spotted cucumber beetles can vector E. tracheiphila (65), their role in transmission of the disease has been largely overlooked. 
Transmission of the pathogen. Bacterial wilt transmission occurs from contact of plant wounds with bacteria-infested frass and in some cases from contaminated beetle mouthparts (66). Rand and Enlows (66) were the first to isolate E. tracheiphila from beetle mouthparts, digestive tracts, and frass; they demonstrated infectivity by inoculating bacterial cultures that had been isolated from beetles onto cucumber seedlings. However, dynamics of the pathogen inside the beetle gut and transmission via bacteria-infested frass were not explored until recently.

Once it became possible to directly detect E. tracheiphila within the alimentary canal of striped CB, researchers began to investigate the pathogen-vector association.

Immunolocalization and ELISA assays on laboratory-reared striped CBs that were allowed to feed on E. tracheiphila 'sandwiches' (cucumber cotyledons smeared with E. tracheiphila cultures) demonstrated the presence of bacterial populations inside beetle digestive systems (31). Although bacterial populations decreased significantly during the first 3 days after feeding, some bacterial cells continued to be detected up to 35 days after acquisition of the pathogen. These assays confirmed the presence of E. tracheiphila inside the digestive tract of striped CB and strengthened evidence that this species could serve as a long-term vector and reservoir of $E$. tracheiphila (32).

Mitchell and Hanks (51) elegantly demonstrated transmissibility of E. tracheiphila via frass by inoculating cucumber seedlings with frass collected from striped CB adults that had fed on E. tracheiphila. Plants wilted after inoculation with frass that had been collected up to two days after beetle infestation, and real-time PCR detected bacterial DNA in frass up to $48 \mathrm{~h}$ after acquisition. Longer acquisition periods increased pathogen retention in striped CB adults: when beetles fed on cotyledon sandwiches for 7 days, bacterial DNA was detected in frass up to four days after the acquisition period (54). 
A similar effect of prolonged E. tracheiphila retention with increased feeding periods was observed using a different probe in real-time PCR (77): Although E. tracheiphila populations dropped significantly five days after ingestion by striped CB, E. tracheiphila was detected up to four weeks after beetles were infested. The durability of vectoring by striped CB, as well as factors that may influence acquisition and retention of the pathogen within the gut, remain uncertain. Variable results in these studies could be explained by the use of different techniques for detection and quantification of E. tracheiphila in frass or the striped CB gut, and bacterial strain variability $(32,54,77)$.

An alternate route of infection through floral nectaries was recently described in a wild gourd (Cucurbita pepo ssp. texana). Field experiments in Pennsylvania suggested that beetle aggregation and deposition of bacteria-infested frass in male and female flowers may result in high incidence of bacterial wilt later in the growing season (75). PCR detection of bacterial DNA collected from frass deposited in wild gourd flowers found that 95\% of the blooms were positive for E. tracheiphila. In greenhouse assays, artificial inoculation through floral nectaries resulted in $42 \%$ wilt incidence. Whether this route of infection contributes to bacterial epidemics in commercial cucurbit fields remains unknown. However, preliminary evidence indicated that $E$. tracheiphila can cause infection on cantaloupe after artificial inoculation through flowers (34).

The impact of temperature and moisture on the transmission of E. tracheiphila is unknown. Smith and others observed that disease development was favored by moist weather conditions $(66,78)$. Preliminary work by Brust (8) suggested that E. tracheiphila could survive and infect muskmelon up to six hours after inoculum had been placed on leaf surfaces. A recent study (72) found that epiphytic populations of E. tracheiphila remained viable for up to two days on muskmelon leaves in a growth chamber, even after exposure to dry environmental conditions. 
It is therefore possible that epiphytic populations serve as a reservoir of inoculum when deposited onto leaf or floral surfaces.

Chemical ecology of beetles. One way to gain insight into the epidemiology of bacterial wilt is to look into the coevolutionary association of cucumber beetles and the Cucurbitaceae family. Researchers conjecture that specialization of diabroticite species to cucurbit host plants originated from ancestral beetles that served as pollinators of cucurbits (53).

Chemical ecologists revealed that cucurbits produce chemical compounds, including cucurbitacin and certain plant volatiles that play major roles in host-plant localization and beetle feeding behavior $(47,53)$. Cucurbitacins are extremely bitter-tasting plant compounds that are ubiquitous in cotyledons, leaves, roots, and fruit of most cucurbit species. Cucurbitacins serve as feeding deterrents to protect plants from insect herbivory - except by diabroticites. Instead, cucurbitacins stimulate locomotive arrest and compulsive feeding by cucumber beetles on cucurbit hosts (27). In fact, ingesting cucurbitacins may protect cucumber beetles from birds and predaceous insects - a potential explanation for the evolutionary value of tolerance to cucurbitacins (53). Cucurbit floral volatiles, on the other hand, help cucumber beetles to find host plants over long distances. Olfactory attraction to cucurbit blossoms may lead Diabrotica adults to pollen, an important component of their diets (79). Guided by these volatiles, beetles can find cucurbit fields and aggregate in blossoms to feed and mate. The recent discovery that bacterial wilt infection may also occur via floral nectaries suggests that attraction to floral volatiles may be a more important factor in bacterial wilt epidemics than previously considered (75).

Pathogen-induced volatiles. Striped CBs aggregate on symptomatic cucumber plants (55, 80, 92). Preferential feeding on wilted plants may be associated with high levels of 
cucurbitacins in symptomatic tissue. A cage assay showed that wilting cucumber plants induced significant beetle aggregation as well as increased levels of cucurbitacins compared to nonwilted plants (38).

Abundant evidence indicates that insect herbivory and pathogen infection can alter volatile plant emissions that influence disease dynamics (52). Could E. tracheiphila induce hostplant changes to manipulate vector behavior? Intriguingly, Shapiro et al (76) recently demonstrated that E. tracheiphila infection can impact volatile emissions by C. pepo ssp. texana leaves and flowers. In field trials and feeding choice assays, striped CBs aggregated and preferred to feed on symptomatic leaves over healthy leaves. However, healthy flowers were significantly more attractive than flowers collected from bacterial wilt-infected plants.

These results suggest that E. tracheiphila infection may alter plant traits to modify beetle behavior and promote its own dispersal in the field. Beetle aggregation on symptomatic leaves ensures pathogen acquisition and dissemination. As floral nectaries were shown to be an alternate route of infection (75), olfactory cues attracting beetles to healthy flowers could promote E. tracheiphila infections, suggesting a subtle but effective strategy by the pathogen to promote its dissemination (76).

Vector and disease seasonal dynamics. Beetle behavior and population density strongly influence the severity of bacterial wilt epidemics. In Pennsylvania, overwintering striped CBs are presumed to be the main source of inoculum for bacterial wilt infections (29). Adult striped CBs overwinter underneath plant debris, usually near cucurbit fields, and become active when air temperatures are $>12^{\circ} \mathrm{C}(36,64)$. In the Midwest, high numbers of overwintering striped CBs move into cucurbit fields during late April through June (10, 64). Mass immigration into cucurbit fields seems to be strongly influenced by attraction to volatiles emitted by seedlings (47). 
Field assays have shown that only a small proportion of overwintering beetles are able to transmit E. tracheiphila early in the season $(10,23)$. In Indiana, a four-year study determined that less than $1 \%$ of overwintering beetles transmitted the pathogen; in Pennsylvania, approximately 7 to $10 \%$ of overwintering beetles tested positive for E. tracheiphila $(10,29)$.

Aggregation behavior increases bacterial wilt transmission. Although few beetles can transmit E. tracheiphila, concentrated feeding damage raises the odds of bacterial wilt infection early in the season. In greenhouse experiments, muskmelon plants were $50 \%$ more likely to develop wilt when inoculum was placed on leaves with larger wounds (8).

The hypothesis that beetle density was strongly and positively correlated to bacterial wilt development is supported by regression analyses based on field experiments (92). A similar effect was observed in greenhouse experiments on muskmelon: preferential feeding of beetles on certain cultivars, perhaps due to visual or gustatory cues, was correlated with greater feeding damage and higher bacterial wilt incidence (13).

In addition to plant volatiles, striped CB males referred to as 'pioneer males' produce an aggregation pheromone once they locate and start feeding on cucurbit plants (82). This behavior is seemingly unaffected by cucurbitacin consumption and more likely associated to male feeding rates or other semiochemical signals (81). The evolutionary reason behind the production of this pheromone remains unclear; however, this behavior may serve as an effective strategy to maximize early-season colonization of host plants (82).

Overwintering females lay their eggs at the base of cucurbit plants, where larvae will feed on roots and develop into first-generation adults $(25,26)$. First-generation beetles (progeny of the overwintering adults) emerge on site and, depending on the geographic region and prevailing temperatures, two or more striped CB generations may occur in a growing season. In the 
Midwest, first-generation beetles emerge in early to mid-July (10). There is no evidence of transovarian transmission of E. tracheiphila to offspring; consequently, newly emerged adults must feed on E. tracheiphila-infected plants in order to acquire and further disseminate the pathogen. Depending on the number of beetle generations and geographic region, first- or second-generation striped CBs are responsible for disease carryover to the following growing season.

During the latter part of the growing season, the incidence of beetles carrying $E$. tracheiphila may be substantially higher (8-78\%) than in overwintering beetles. Nevertheless, field studies and observations suggest that the risk of current-season bacterial wilt infection decreases as the season progresses $(10,29)$. This could be explained by lower beetle densities due to death of overwintering adults or migration to other cucurbit fields, or to a reduced attractiveness of mature cucurbit plants to beetles, possibly due to lower levels of cucurbitacin (85). It is also feasible that plants may become less susceptible to infection as they develop and increase in size. It has been shown that symptom development on artificially-inoculated cucumber and muskmelon seedlings is dependent on E. tracheiphila cell concentrations (49).

\section{BACTERIAL WILT MANAGEMENT}

Insecticides and kairomonal baits. The first weeks after transplant are critical for bacterial wilt suppression, mainly because early-season beetle damage can pose a high risk of bacterial wilt transmission. Field assays in Alabama demonstrated that during the first weeks of beetle colonization, one beetle per plant was associated with a wilt incidence of approximately $20 \%$ among muskmelon vines (92).

Because of the unavailability of commercially resistant cultivars and high risk of bacterial wilt transmission even at low beetle densities; cucurbit bacterial wilt management has relied 
heavily on insecticide applications (69). Conservative economic thresholds for striped CBs often lead to either preventative insecticide applications or calendar-based applications begun at first sight of beetles in the field $(15,29)$. In the U.S., cucumber beetles are commonly managed using systemic insecticides on seeds or transplants before planting, or in the furrow during planting (21). In Pennsylvania, application of imidacloprid, a neonicotinoid insecticide, to seedlings resulted in reduced striped CB colonization and bacterial wilt transmission (30). Although bacterial wilt symptoms were observed in the field, low doses of systemic insecticides applied at planting controlled striped CB colonization with moderate success while reducing the need for weekly foliar applications of insecticides $(2,30)$

Contact insecticides, mainly carbaryl and pyrethroids, can be applied after systemic insecticides are no longer effective or when beetle populations are high (24). However, numerous foliar applications may be required throughout the growing season to adequately control beetle immigration, and even at 7-day interval applications, bacterial wilt transmission may occur (12). When facing high striped CB populations, it is not unusual for growers to deploy insecticides at 5-day intervals, which can sum up to 8 to 10 applications in a single season (11, 42).

Whether systemic or contact insecticides are used to manage cucumber beetle populations, routine scouting is recommended to reduce unnecessary pesticide applications. In the Midwest, Brust and Foster (11) established an action threshold of one beetle per plant for adequate protection against cucumber beetle damage and bacterial wilt. Implementation of action thresholds along with direct scouting and/or the use of yellow sticky traps can effectively control bacterial wilt while avoiding several insecticide sprays on muskmelon $(15,43)$. 
Kairomonal baits have been used as an alternative to weekly insecticide applications. Toxic baits containing cucurbitacins and floral volatiles in combination with carbaryl reduced beetle damage in the field $(12,28)$. In Indiana, baits significantly reduced beetle feeding damage when compared to untreated plants (12). However, toxic baits did not provide rapid beetle knockdown, and because bacterial wilt transmission may occur even at low beetle densities, rapid knockdown is essential for adequate disease control (12). Additionally, effectiveness of kairomonal baiting methods and traps can vary among diabroticite species and between genders (26).

Perimeter trap cropping. During the past 20 years, research efforts have emphasized “alternative” approaches to manage cucumber beetles with less insecticide use (15, 60, 63, 73). A perimeter trap crop (PTC) approach consists of planting a border that can intercept incoming pests and applying insecticide to the PTC, thereby protecting the main crop from damage (6). In a cucurbit cropping system, PTC exploits cucumber beetle feeding preferences and aggregation feeding patterns by selecting highly attractive border plants (1). In New England, PTC reduced insecticide applications by $>90 \%$ on a butternut squash main crop, and acceptable bacterial wilt control was achieved by monitoring beetle populations and focusing most insecticide applications on the Hubbard squash trap crop (18). In preliminary trials, use of PTC has also been shown to effectively control bacterial wilt on muskmelon main crop in Iowa and Ohio (4).

Row covers. Row covers are commonly used in vegetable crops to enhance earliness of yield and protect plants from harsh weather and insect pests (59, 87). In Iowa, deployment of non-woven polypropylene row covers during transplant protected muskmelon against bacterial wilt without the need of insecticide applications $(56,73)$. Traditionally, row covers are removed at anthesis (first appearance of female flowers) on cucurbit crops to enable pollination and avoid 
harvest delays (35). Interestingly, delaying removal of row covers until 10 days after anthesis reduced bacterial wilt incidence in Iowa field trials by 33 to 50\% compared to row cover removal at anthesis and non-covered controls, respectively (73).

Continuing to provide a row cover barrier after the start of the bloom period delays not only cucumber beetle access but also bee access, which can delay pollination and harvest. This delay could be a disadvantage for growers in wholesale outlets with highly volatile prices (12). A compensatory strategy - opening row cover ends or introducing purchased or captured bees under the row covers after anthesis - has been shown to enable pollination and avoid harvest delays (2012 OREI progress report).

Biological control. Few studies have focused on biological control methods against cucumber beetles. Tachinid flies and braconid wasps have been reported to parasitize SBCs; however, the impact of these species on cucumber beetle management in field conditions has not been quantified (83).

Soil management practices and deployment of plastic mulches have been shown to reduce cucumber beetle populations in muskmelon, cucumber, and squash $(3,58)$. Aluminum coated or reflective mulches have been shown to repel cucumber beetles with variable results, whereas black plastic mulch can reduce larval survival of striped CBs $(16,58)$. Control of cucumber beetle larvae has been achieved by introducing entomopathogenic nematodes near the roots of cucumbers grown in black plastic mulch (26). This method could be integrated into a cucurbit system to decrease beetle populations mid-summer; however, it would not provide control of early season or overwintering beetle populations.

Plant growth-promoting rhizobacteria (PGPR) applied as a seed treatment on cucumber seeds have been shown to significantly reduce bacterial wilt incidence in greenhouse and field 
experiments (93). It is believed that PGPR may induce systemic resistance against $E$.

tracheiphila and other cucumber pathogens and also deter cucumber beetle feeding by reducing cucurbitacin levels in plant tissues $(68,94)$.

\section{OUTLOOK: DISCOVERING MORE PIECES OF THE PUZZLE}

An increased awareness of pesticide hazards to human health and non-target organisms (i.e., pollinators and beneficial insects) has propelled arguments for reducing pesticide reliance and substituting or supplementing with non-chemical pest management strategies. In the case of cucurbit bacterial wilt, our rudimentary understanding of genetic and ecological components of the pathosystem has been a major barrier to developing effective ecologically based disease strategies. In this section, we highlight progress in understanding ecological, genetic, and epidemiological aspects of the bacterial wilt pathosystem, while also pointing out important areas that remain largely unexplored.

Pathogenicity and host specificity. With the recent discovery of clearly-defined genetic patterns and virulence differences among E. tracheiphila strains, it is reasonable to presume that strain adaptation could be driven by host selection pressure (71). However, it is evident that in order to understand the nature of host specificity we first need to gain a better understanding of virulence factors characterizing $E$. tracheiphila infection processes.

For example, could extracellular polysaccharide (EPS) production be a major pathogenicity mechanism for E. tracheiphila infections? It is alleged that E. tracheiphila pathogenicity depends on rapid multiplication of cells within the xylem system. Similar pathosystems have been shown to rely on EPS production for host colonization and symptom development (19), and although the role of EPS in pathogenicity of E. tracheiphila is uncertain, preliminary research has reported variable rates of EPS production among E. tracheiphila strains 
(C.K. Dumenyo, Tennessee State University, personal communication). Further insight into the chemical and physical properties of EPS production and biofilm formation by E. tracheiphila may explain colonization processes and symptom progression at different plant growth stages and among different host species (20).

Preliminary genome sequencing data for E. tracheiphila provides some clues to genes associated with pathogenicity and host specificity mechanisms. For example, Zhao et. al. (University of Illinois, personal communication) identified genes encoding components of a type III secretion system. Complete sequencing of E. tracheiphila strains could help identify genes encoding additional virulence factors, which could help explain the evolutionary association between E. tracheiphila and cucurbits and possibly translate into more effective disease management strategies. Moreover, a deeper understanding of E. tracheiphila genetics could hasten breeding efforts to develop disease-resistant cultivars.

Vector-pathogen interactions. Despite a seemingly close evolutionary association between cucumber beetles and E. tracheiphila, the details of this interaction remain unknown. $E$. tracheiphila is known to overwinter and survive in the digestive system of striped CB; however, it is unclear whether striped CBs can serve as long- or short-term disease vectors. Mitchell and Hanks observed variable results in retention of $E$. tracheiphila by striped CB beetles frass when using different bacterial strains (54).

Could E. tracheiphila strain differences influence acquisition, retention, and transmission by cucumber beetles? In other vector-transmitted bacterial pathosystems, strain differences can significantly impact vector competence (48). Furthermore, it was recently demonstrated that the Stewart's disease pathogen, Pantoea stewartii, incorporates an additional Type III Secretion System (T3SS) for retention and transmission by flea beetles (19). Similar approaches to explore 
the symbiotic relationship between E. tracheiphila and cucumber beetles could provide insights on new avenues for suppressing bacterial wilt.

Geographic range. Given that E. tracheiphila host crops and vectors are commonly found throughout the United States and other continents, why does cucurbit bacterial wilt appear to be limited to a fraction of North America? Specific vector-pathogen associations could impact pathogen dispersal. However, because striped CB seasonal dynamics play a crucial role in the epidemiology of bacterial wilt, beetle behavior, feeding preferences, and colonization patterns in different geographic areas and among closely related diabroticites could help explain the spatial distribution of E. tracheiphila. For example, spotted cucumber beetles are known to transmit $E$. tracheiphila, but their impact in disease epidemics remains unknown.

Ecology-based management approaches. In the absence of commercial disease resistant cucurbit cultivars, more effective beetle control methods such as cultural practices, reduced-risk insecticides, and striped CB population prediction tools must be developed. Nonchemical strategies such as row covers and PTC can be effective; however, row covers are labor intensive and expensive and PTC systems have been validated only in a few crops and states in the U.S. In order to promote adoption of row covers among commercial growers, it is critical to mechanize row cover deployment and removal. Field trials developing feasible row cover and PTC strategies are currently being validated by several authors of this paper.

Additionally, phenological models predicting cucumber beetle arrival and emergence could prompt growers away from calendar-based applications, reducing the number of sprays in a single season. 


\section{Forming future professionals using case studies}

Active learning. Traditional teaching strategies emphasize on delivering large amounts of factual knowledge to learners $(86,87)$. In a traditional college setting, students passively listen to information, often in the form of lectures, and then are asked to recall the material in the form of tests and assignments. This style of teaching often proves to be ineffective when students are expected to understand and synthesize complex concepts $(57,61)$. In contrast, active learning strategies can enhance a deeper understanding of the subject matter and development of problem-solving skills $(40,86)$.

Numerous definitions of active learning have been used in the past decades $(61,70)$; however, active learning will be defined here as implementing educational activities that engage students in the learning process (41). Rather than merely providing factual information to students, active learning strategies contextualize knowledge by facilitating student's interactions with teachers and peers. Active learning experiences are truly student-centered, creating a more responsible and collaborative learner $(41,62)$.

Active learning can be enhanced by introducing simple interactive activities into a traditional lecture period (17). Activities to improve engagement in the classroom can be as simple as asking learners to think about their learning process $(95,96)$. For example, promoting self-reflection, meaning that students become aware of their knowledge and thinking process, can significantly improve their ability to focus, value knowledge, and maximize overall performance (96). Learner-centered strategies that are especially useful in large classrooms can include inquiry-based learning and collaborative work with peers (22). These types of activities 
can be used to fulfill learning objectives while promoting discussion and stimulating application of knowledge and analytical skills among students.

Case studies. Introducing active-learning teaching methods into higher education has proven to be critical across disciplines to build adaptable, thinking professionals (70). In general, case study teaching methods entail introducing a realistic problem, and empowering students to pursue solutions to the problem by applying theoretical principles and problem-solving skills $(17,70)$.

Exposing college students to realistic narratives in which they practice decision-making not only can make classes more engaging, but it also allows learners to stop thinking as students and relate to knowledge by assuming the roles of professional decision-makers (57). Casemethod strategies provide enough factual information to enable students to analyze the situation presented in the case, generally involving discussion with other classmates.

\section{Research justification}

Cucurbit bacterial wilt, caused by Erwinia tracheiphila, is an important bacterial disease that affects most commercial cucurbit species in the Mid-Atlantic United States. This vascular pathogen is overwintered and transmitted by cucumber beetles. Management of bacterial wilt relies on controlling insect vectors, which often involves the intensive use of insecticides. In order to develop effective management alternatives against cucurbit bacterial wilt with less reliance on environmentally hazardous insecticides, it is essential to unravel vector, plant host, and pathogen interactions in this complex pathosystem. With the purpose of achieving a better understanding of the factors impacting pathogen biology and bacterial wilt disease development, the following research objectives were undertaken: 
1. Assess efficacy of delayed removal of row covers for suppressing bacterial wilt on muskmelon, and compare costs and returns of row cover treatments.

2. Evaluate whether E. tracheiphila survives on muskmelon leaves, and assess how survival is influenced by environmental conditions.

3. Investigate the genetic diversity of E. tracheiphila.

In addition carrying out research objectives, a fourth non-research objective consisted of developing an educational tool in the form of a case study, for implementation in undergrad education across multiple disciplines. The objectives of this case study were to actively engage students and promote problem-solving skills in a realistic pest-management situation, using bacterial wilt as an example. Upon completion of the case study, students will be able to recognize basic plant pathology concepts, identify Integrated Pest Management (IPM) strategies, and create their own management approach. 


\section{Literature Cited}

1. Adler, L. S., and Hazzard, R. V. 2009. comparison of perimeter trap crop varieties: effects on herbivory, pollination, and yield in butternut squash. . Environmental entomology 38:207-215.

2. Allen, J. K. M. I., Scott-Dupree, C. D., Tolman, J. H., and Harris, C. R. 2001. Evaluation of application methods for the chemical control of striped cucumber beetle (Coleoptera: Chrysomelidae) attacking seedling cucurbits. Journal of Vegetable Crop Production 7:8395.

3. Andino, J. R., and Motsenbocker, C. E. 2004. Colored plastic mulches influence cucumber beetle populations, vine growth, and yield of watermelon. HortScience 39:1246-1249.

4. Bartel, R. 2012. Protecting against bacterial wilt. Pages 26-28 in: American Vegetable Grower.

5. Bassi, A., Jr. 1983. The overwintering nature of Erwinia tracheiphila (Smith) and resistance to bacterial wilt in cucumber. Dissertation Abstracts International, B 43:3088B.

6. Boucher, T. J., and Durgy, R. 2004. Demonstrating a perimeter trap crop approach to pest management on summer squash in New England. Journal of Extension 42:Rb2.

7. Brenner, D. J., Fanning, G. R., and Steigerwalt, A. G. 1974. Deoxyribonucleic acid relatedness among Erwiniae and other Enterobacteriaceae; the gall, wilt and dry-necrosis organisms (genus Erwinia Winslow et al., sensu stricto). International Journal of Systematic Bacteriology 24:197-204. 
8. Brust, G. 1997. Interaction of Erwinia tracheiphila and muskmelon plants. Environmental Entomology 26:849-854.

9. Brust, G. E. 1997. Differential susceptibility of pumpkins to bacterial wilt related to plant growth stage and cultivar. Crop Protection 16:411-414.

10. Brust, G. E. 1997. Seasonal variation in percentage of striped cucumber beetles (Coleoptera: Chrysomelidae) that vector Erwinia tracheiphila. Environmental Entomology 26:580-584.

11. Brust, G. E., and Foster, R. E. 1999. New economic threshold for striped cucumber beetle (Coleoptera: Chrysomelidae) in cantaloupe in the midwest. Journal of Economic Entomology 92:936-940.

12. Brust, G. E., and Foster, R. E. 1995. Semiochemical-based toxic baits for control of striped cucumber beetle (Coleoptera: Chrysomelidae) in cantaloupe. Journal of Economic Entomology 88:112-116.

13. Brust, G. E., and Rane, K. K. 1995. Differential occurrence of bacterial wilt in muskmelon due to preferential striped cucumber beetle feeding. HortScience 30:10431045.

14. Burkholder, W. H. 1960. Some observations on Erwinia tracheiphila, the causal agent of cucurbit wilt. Phytopathology 50:179-180 pp.

15. Burkness, E. C., and Hutchison, W. D. 1998. Development and validation of a fixedprecision sampling plan for estimating striped cucumber beetle (Coleoptera: Chrysomelidae) density in cucurbits. Environmental Entomology 27:178-183.

16. Caldwell, J. S., and Clarke, P. 1999. Repulsion of cucumber beetles in cucumber and squash using aluminum-coated plastic mulch. HortTechnology 9:247-250. 
17. Carlson, J. A., and Schodt, D. W. 1995. Beyond the lecture: Case teaching and the learning of economic theory. Journal of Economic Education:17-28.

18. Cavanagh, A., Hazzard, R., Adler, L. S., and Boucher, J. 2009. Using trap crops for control of Acalymma vittatum (Coleoptera: Chrysomelidae) reduces insecticide use in butternut squash. Journal of Economic Entomology 102:1101-1107.

19. Correa, V. R., Majerczak, D. R., Ammar, E. D., Merighi, M., Pratt, R. C., Hogenhout, S. A., Coplin, D. L., and Redinbaugh, M. G. 2012. The bacterium Pantoea stewartii uses two different type III secretion systems to colonize its plant host and insect vector. Applied and Environmental Microbiology 78:6327-6336.

20. Denny, T. P. 1995. Involvement of bacterial polysaccharides in plant pathogens. Annual Review of Phytopathology 33:173-197.

21. Dively, G. P., and Kamel, A. 2012. Insecticide residues in pollen and nectar of a cucurbit crop and their potential exposure to pollinators. Journal of Agricultural and Food Chemistry 60:4449-4456.

22. Dochy, F., Segers, M., and Sluijsmans, D. 1999. The use of self-, peer and co-assessment in higher education: A review. Studies in Higher education 24:331-350.

23. Doolittle, S. P. 1921. Overwintering of the bacterial wilt of Cucurbits. Phytopathology 11:290 p.

24. Egel, D., Foster, R. E., Maynard, E., Weinzierl, R., Babadoost, M., O'Malley, P., Nair, A., Cloyd, R., Rivard, C., Kennelly, M., Hutchinson, B., and Gu, S. 2013. Midwest Vegetable Production Guide for Commercial Growers 2013. Page 208 Purdue Extension. 
25. Ellers-Kirk, C., and Fleischer, S. J. 2006. Development and life table of Acalymma vittatum (Coleoptera: Chrysomelidae), a vector of Erwinia tracheiphila in cucurbits. Environmental Entomology 35:875-880.

26. Ellers-Kirk, C. D., Fleischer, S. J., Snyder, R. H., and Lynch, J. P. 2000. Potential of entomopathogenic nematodes for biological control of Acalymma vittatum (Coleoptera: Chrysomelidae) in cucumbers grown in conventional and organic soil management systems. Journal of Economic Entomology 93:605-612.

27. Ferguson, J. E., and Metcalf, R. L. 1985. Cucurbitacins: plant-derived defense compounds for diabroticites (Coleoptera: Chrysomelidae). Journal of Chemical Ecology $11: 311-318$.

28. Fleischer, S. J., and Kirk, D. 1994. Kairomonal baits: effect on acquisition of a feeding indicator by Diabroticite vectors in cucurbits. Environmental Entomology 23:1138-1149.

29. Fleischer, S. J., Mackiewicz, D. d., Gildow, F. E., and Lukezic, F. L. 1999. Serological estimates of the seasonal dynamics of Erwinia tracheiphila in Acalymma vittata (Coleoptera: Chrysomelidae). Environmental Entomology 28:470-476.

30. Fleischer, S. J., Orzolek, M. D., Mackiewicz, D. d., and Otjen, L. 1998. Imidacloprid effects on Acalymma vittata (Coleoptera: Chrysomelidae) and bacterial wilt in cantaloupe. Journal of Economic Entomology 91:940-949.

31. Garcia-Salazar, C., Gildow, F., Fleischer, S. J., Cox-Foster, D., and Lukezic, F. L. 2000. Alimentary canal of adult Acalymma vittata (Coleoptera: Chrysomelidae): morphology and potential role in survival of Erwinia tracheiphila (Enterobacteriaceae). Canadian Entomologist 132:1-13. 
32. Garcia-Salazar, C., Gildow, F. E., Fleischer, S. J., Cox-Foster, D., and Lukezic, F. L. 2000. ELISA versus immunolocalization to determine the association of Erwinia tracheiphila in Acalymma vittatum (Coleoptera: Chrysomelidae). Environmental Entomology 29:542-550.

33. Garrity, G. M. 2005. Bergey's Manual of Systematic Bacteriology.

34. Gautam, D., MA, L., Bruton, B., and Fletcher, J. 2011. Erwinia tracheiphila colonization of cantaloupe fruits through flower inoculation. Phytopathology.

35. Gaye, M. M., Maurer, A. R., and Seywerd, F. M. 1991. Honey bees placed under row covers affect muskmelon yield and quality. Scientia Horticulturae 47:59-66.

36. Gould, G. E. 1944. The Biology and Control of the Striped Cucumber Beetle. Buil. Ind. agric. Exp. Stn.:28 pp.

37. Hauben, L., Moore, E. R. B., Vauterin, L., Steenackers, M., Mergaert, J., Verdonck, L., and Swings, J. 1998. Phylogenetic Position of Phytopathogens within the Enterobacteriaceae. Systematic and Applied Microbiology 21:384-397.

38. Haynes, R. L., and Jones, C. M. 1975. Wilting and damage to cucumber by spotted and striped cucumber beetles. HortScience 10:265-266.

39. Hoffmann, M. P., Ramesh, A., and Kirkwyland, J. J. 2000. Yield response of pumpkin and winter squash to simulated cucumber beetle (Coleoptera: Chrysomelidae) feeding injury. Journal of Economic Entomology 93:136-140.

40. Jonassen, D. H. 2000. Toward a design theory of problem solving. Educational technology research and development 48:63-85. 
41. Kolb, A. Y., and Kolb, D. A. 2005. Learning styles and learning spaces: Enhancing experiential learning in higher education. Academy of management learning \& education 4:193-212.

42. Lam, F., and Foster, R. E. 2006. Monitoring and decision making for cucumber beetles on muskmelon. P. University. Pub. No. E-101-W.

43. Lam, W. F. 2007. An alternative sampling technique for cucumber beetles (Coleoptera: Chrysomelidae) and diurnal beetle activity on muskmelon. Journal of Economic Entomology 100:823-829.

44. Latin, R. X. 2000. Bacterial Wilt. in: APSnet Features APSnet.

45. Latin, R. X. 1993. Diseases and pests of muskmelons and watermelon. P. U. Extension. Pub. No. BP-44.

46. Leach, J. G. 1964. Observations on cucumber beetles as vectors of cucurbit wilt. Phytopathology 54:606-607.

47. Lewis, P. A., Lampman, R. L., and Metcalf, R. L. 1990. Kairomonal attractants for Acalymma vittatum (Coleoptera: Chrysomelidae). Environmental Entomology 19:8-14.

48. Lopes, J. R. S., Daugherty, M. P., and Almeida, R. P. P. 2009. Context-dependent transmission of a generalist plant pathogen: host species and pathogen strain mediate insect vector competence. Entomologia Experimentalis et Applicata 131:216-224.

49. Lukezic, F. L., Sackett, W. M., Fleischer, S. J., Orzolek, M. D., and Gildow, F. E. 1996. Influence of concentration of Erwinia tracheiphila cells on the development of wilt symptoms in field-grown cucumbers and cantaloupe plants. Phytopathology 86. 
50. Mackiewicz, D. d., Gildow, F. E., Blua, M., Fleischer, S. J., and Lukezic, F. L. 1998. Herbaceous weeds are not ecologically important reservoirs of Erwinia tracheiphila. Plant Disease 82:521-529.

51. Main, C. E., and Walker, J. C. 1971. Physiological responses of susceptible and resistant cucumber to Erwinia tracheiphila. Phytopathology 61:518-522.

52. Mann, R. S., Ali, J. G., Hermann, S. L., Tiwari, S., Pelz-Stelinski, K. S., Alborn, H. T., and Stelinski, L. L. 2012. Induced Release of a Plant-Defense Volatile ‘Deceptively’ Attracts Insect Vectors to Plants Infected with a Bacterial Pathogen. PLoS Pathog 8:e1002610.

53. Metcalf, R. L., and Lampman, R. L. 1989. The chemical ecology of diabroticites and cucurbitaceae. Experientia 45:240-247.

54. Mitchell, R. F., and Hanks, L. M. 2009. Insect frass as a pathway for transmission of bacterial wilt of cucurbits. Environmental Entomology 38:395-403.

55. Moran, P. J. 2001. The effects of wilt symptom development and peroxidase induction on interactions between vascular wilt bacteria and cucumber beetles. Entomologia Experimentalis et Applicata 98:149-156.

56. Mueller, D. S., Gleason, M. L., Sisson, A. J., and Massman, J. M. 2006. Effect of row covers on suppression of bacterial wilt of muskmelon in Iowa. Plant Health Progress:1-7.

57. Myrick, F., and Yonge, O. 2004. Enhancing critical thinking in the preceptorship experience in nursing education. Journal of advanced nursing 45:371-380.

58. Necibi, S., Barrett, B. A., and Johnson, J. W. 1992. Effects of a black plastic mulch on the soil and plant dispersal of cucumber beetles, Acalymma vittatum (F.) and Diabrotica 
undecimpunctata howardi Barber (Coleoptera: Chrysomelidae) on melons. Journal of Agricultural Entomology 9:129-135.

59. Orozco-S, M., Lopez-A, O., Perez-Z, O., and Delgadillo-S, F. 1994. Effect of transparent mulch, floating row covers and oil sprays on insect populations, virus diseases and yield of cantaloup. Biological Agriculture \& Horticulture 10:229-234.

60. Pair, S. D. 1997. Evaluation of Systemically Treated Squash Trap Plants and Attracticidal Baits for Early-Season Control of Striped and Spotted Cucumber Beetles (Coleoptera: Chrysomelidae) and Squash Bug (Hemiptera: Coreidae) in Cucurbit Crops. Journal of Economic Entomology 90:1307-1314.

61. Prince, M. 2004. Does active learning work? A review of the research. Journal of engineering education 93:223.

62. Prince, M. J., and Felder, R. M. 2006. Inductive teaching and learning methods: Definitions, comparisons, and research bases. Journal of Engineering Education 95:123138.

63. Radin, A. M., and Drummond, F. A. 1994. An evaluation of the potential for the use of trap cropping for control of the striped cucumber beetle, Acalymma vittata (F.) (Coleoptera: Chrysomelidae). Journal of Agricultural Entomology 11:95-113.

64. Radin, A. M., and Drummond, F. A. 1994. Patterns of initial colonization of cucurbits, reproductive activity, and dispersion of striped cucumber beetle, Acalymma vittata (F.) (Coleoptera: Chrysomelidae). Journal of Agricultural Entomology 11:115-123.

65. Rand, F. V., and Cash, L. C. 1920. Some Insect Relations of Bacillus tracheiphilus, Erw. Sm. Phytopathology 10:133-140 pp. 
66. Rand, F. V., and Enlows, E. M. A. 1920. Bacterial Wilt of Cucurbits. Bulletin. United States Department of Agriculture:43 pp.

67. Rand, F. V., and Enlows, E. M. A. 1916. Transmission and Control of Bacterial Wilt of Cucurbits. Journal of Agricultural Research 6:417-434 pp.

68. Raupach, G. S., and Kloepper, J. W. 1998. Mixtures of plant growth-promoting rhizobacteria enhance biological control of multiple cucumber pathogens. Phytopathology 88:1158-1164.

69. Reed, G. L., and Stevenson, W. R. 1984. Bacterial wilt resistance in commercial muskmelon cultivars. Proceedings of the Indiana Academy of Science 94:131-140.

70. Richards, L. G. 1995. Promoting active learning with cases and instructional modules. Journal of engineering education 84:375.

71. Saalau Rojas, E., Dixon, P. M., Batzer, J. C., and Gleason, M. L. 2013. Genetic and virulence variability among Erwinia tracheiphila strains recovered from different cucurbit hosts. Phytopathology In press.

72. Saalau Rojas, E., and Gleason, M. L. 2012. Epiphytic survival of Erwinia tracheiphila on muskmelon ( Cucumis melo L.). Plant Disease 96:62-66.

73. Saalau Rojas, E., Gleason, M. L., Batzer, J. C., and Duffy, M. 2011. Feasibility of delaying removal of row covers to suppress bacterial wilt of muskmelon ( Cucumis melo). Plant Disease 95:729-734.

74. Sanogo, S., Etarock, B. F., and Clary, M. 2011. First report of bacterial wilt caused by Erwinia tracheiphila on pumpkin and watermelon in New Mexico. Plant Disease 95:1583. 
75. Sasu, M. A., Seidl-Adams, I., Wall, K., Winsor, J. A., and Stephenson, A. G. 2010. Floral transmission of Erwinia tracheiphila by cucumber beetles in a wild Cucurbita pepo. Environmental Entomology 39:140-148.

76. Shapiro, L., Moraes, C. M. d., Stephenson, A. G., and Mescher, M. C. 2012. Pathogen effects on vegetative and floral odours mediate vector attraction and host exposure in a complex pathosystem. Ecology Letters 15:1430-1438.

77. Shapiro, L. R. S.-A., I.; De Moraes, C.; Stephenson, A.; Mescher, M. 2011. Dynamics of Erwinia tracheiphila acquisition and retention by its insect vector, Acalymma vittatum. in: Entomological Society of America Annual Meeting, Reno, NV.

78. Sherf, A. F., and MacNab, A. A. 1986. Vegetable diseases and their control.

79. Siegfried, B. D., and Mullin, C. A. 1990. Effects of alternative host plants on longevity, oviposition, and emergence of western and northern corn rootworms (Coleoptera: Chrysomelidae). Environmental Entomology 19:474-480.

80. Smith, E. F. 1911. Bacteria in relation to plant diseases. Carnegie Institution of Washington, Washington, D.C.

81. Smyth, R. R., and Hoffmann, M. P. 2002. Correspondence between rates of host plant consumption and responses to the Acalymma vittatum male-produced aggregation pheromone. Physiological Entomology 27:235-242.

82. Smyth, R. R., and Hoffmann, M. P. 2003. A male-produced aggregation pheromone facilitating Acalymma vittatum F. (Coleoptera: Chrysomelidae) early-season host plant colonization. Journal of Insect Behavior 16:347-359. 
83. Smyth, R. R., and Hoffmann, M. P. 2010. Seasonal incidence of two co-occurring adult parasitoids of Acalymma vittatum in New York State: Centistes (Syrrhizus) diabroticae and Celatoria setosa. BioControl 55:219-228.

84. Starr, M. P., and Mandel, M. 1950. The nutrition of phytopathogenic bacteria. IV. Minimal nutritive requirements of the genus Erwinia. Journal of Bacteriology 60:669-672 pp.

85. Tallamy, D. W., and Krischik, V. A. 1989. Variation and Function of Cucurbitacins in Cucurbita: An Examination of Current Hypotheses. The American Naturalist 133:766786.

86. Tiwari, A., Lai, P., So, M., and Yuen, K. 2006. A comparison of the effects of problem-based learning and lecturing on the development of students' critical thinking. Medical education 40:547-554.

87. Vaissiere, B. E., and Froissart, R. 1996. Pest management and pollination of cantaloupes grown under spunbonded row covers in West Africa. Journal of Horticultural Science 71:755-766.

88. Watterson, J. C., Williams, P. H., and Durbin, R. D. 1972. Multiplication and movement of Erwinia tracheiphila in resistant and susceptible cucurbits. Plant Disease Reporter 56:949-953.

89. Watterson, J. C., Williams, P. H., and Durbin, R. D. 1971. Response of cucurbits to Erwinia tracheiphila. Plant Disease Reporter 55:816-819.

90. Wei, C. T., Walker, J. C., and Scheffer, R. P. 1952. Plant nutrition in relation to disease development. VII. Cucurbit wilts. American Journal of Botany 39:245-249. 
91. Wells, J. M., Zwet, T. v. d., and Hale, C. N. 1994. Differentiation of Erwinia species in the `Amylovora' group by class analysis of cellular fatty acids. Journal of Phytopathology 140:31-38.

92. Yao, C., Zehnder, G., Bauske, E., and Kloepper, J. 1996. Relationship between cucumber beetle (Coleoptera: Chrysomelidae) density and incidence of bacterial wilt of cucurbits. Journal of Economic Entomology 89:510-514.

93. Zehnder, G., Kloepper, J., Yao, C., and Wei, G. 1997. Induction of systemic resistance in cucumber against cucumber beetles (Coleoptera: Chrysomelidae) by plant growthpromoting rhizobacteria. Journal of Economic Entomology 90:391-396.

94. Zehnder, G. W., Murphy, J. F., Sikora, E. J., and Kloepper, J. W. 2001. Application of rhizobacteria for induced resistance. European Journal of Plant Pathology 107:39-50.

95. Zimmerman, B. J. 2002. Becoming a self-regulated learner: An overview. Theory into practice 41:64-70.

96. Zimmerman, B. J., Bonner, S., and Kovach, R. 1996. Developing self-regulated learners: Beyond achievement to self-efficacy. American Psychological Association. 


\title{
CHAPTER 2
}

\section{FEASIBILITY OF DELAYING REMOVAL OF ROW COVERS TO SUPPRESS BACTERIAL WILT OF MUSKMELON (CUCUMIS MELO L.)}

A paper published in Plant Disease (2011, 95:729-734)

E. Saalau-Rojas, M.L. Gleason, J.C. Batzer, and M. Duffy

\begin{abstract}
Bacterial wilt, caused by Erwinia tracheiphila (Smith), is a major disease of cucurbit crops in the U.S. Management of the disease relies on controlling two vector species, striped (Acalymma vitatta (F.)) cucumber beetles and spotted (Diabrotica undecimpunctata Barber) cucumber beetles. Six field trials were conducted at Iowa State University research farms during 2007, 2008, and 2009 to assess the efficacy of delayed removal of spunbond polypropylene row covers to control bacterial wilt on muskmelon (Cucumis melo L.). Treatments were: 1) row cover removed at anthesis (conventional timing of removal); 2) covers removed 10 days after row cover ends were opened at anthesis; 3) covers removed 10 days after bumble bee hives were inserted under row covers at anthesis; and 4) a non-covered control. In two field trials during 2007 and 2008, the delayed-removal row cover treatments significantly suppressed bacterial wilt throughout the growing season and enhanced yield compared to the non-covered and removal-atanthesis controls. In Gilbert in 2008, however, bacterial wilt suppression was equivalent among all three row cover treatments. No bacterial wilt was observed during three trials in 2009, and there was minimal difference in marketable yield among treatments. Net returns were compared using partial budget and sensitivity analyses. Melon prices and occurrence of bacterial wilt had a strong impact on net returns. Using row covers increased production costs by $45 \%$. In site years
\end{abstract}


in which bacterial wilt occurred, delaying removal of row covers resulted in the highest returns. When bacterial wilt was absent, however, the delayed-removal row cover treatments had the lowest returns. Results of the sensitivity analysis indicated that delaying removal of row covers for 10 days could be a cost-effective component of an integrated bacterial wilt suppression strategy for muskmelon where bacterial wilt occurs $\geq 50 \%$ of production seasons.

\section{Introduction}

Bacterial wilt is one of the most important diseases of cucurbits in the eastern United States (6). Muskmelon (Cucumis melo L.) and cucumber (Cucumis sativus L.) are highly susceptible, and all cucurbits except watermelon (Citrullus lanatus (Thunb.)) are also susceptible $(17,39)$. In muskmelon, bacterial wilt can cause yield losses as high as $80 \%(25)$.

Bacterial wilt, caused by Erwinia tracheiphila (Smith), is transmitted by striped cucumber beetles (Acalymma vitatta (F.)) and spotted cucumber beetles (Diabrotica undecimpunctata Barber) (39). Transmission occurs when the mouthparts and frass of infested beetles come into contact with fresh feeding wounds on leaves and stems (27). Bacteria enter the xylem vessels, multiply, and block the vascular system. Symptoms include wilting of leaves and vines followed by collapse and death of the plant (40).

Overwintering adult cucumber beetles may appear in muskmelon fields shortly after transplanting, and management of the disease relies primarily on controlling these vectors (14). Insecticides are widely used in cucurbit crops to suppress cucumber beetles $(4,15)$; as many as eight applications are made in a single season (4). However, effectiveness of insecticide-based management is erratic $(4,33,37)$. Furthermore, foliar insecticide sprays may injure pollinators $(4,15)$ and many are highly toxic to aquatic organisms $(11)$. Additional strategies to improve 
vector control and bacterial wilt suppression include insecticide-spray timing based on cucumber beetle monitoring thresholds $(8,24)$, as well as deployment of perimeter trap crops $(1,37)$, kairomonal baits $(4,19,28)$, and entomopathogenic nematodes (12).

Row covers are spunbonded polypropylene fabrics that protect young plants from harsh weather conditions (41) as well as a range of arthropod pests (7, 35, 36, 43), and facilitate early yield by promoting crop development $(20,44,45)$. In addition, they may also protect muskmelon from cucumber beetles and bacterial wilt (33). The covers are typically removed from muskmelon at the beginning of anthesis to allow pollination; under these circumstances, however, they may not provide consistent season-long protection against the disease (33). In preliminary field trials in Iowa, delaying the removal of row covers until 10 days after anthesis provided durable protection against bacterial wilt (22). Vassiere and Froissart (43) and Gaye et al. (16) also demonstrated that extending the duration of the row-covered period protected muskmelon from late-season frosts, sap-sucking insects, and fruit flies. Later harvest due to delayed fruit set that could result from delaying the removal of row covers could potentially be avoided by supplying bees under the row covers or opening the row cover ends to provide access for pollinators $(16,43)$.

The objectives of this study were to 1 ) assess efficacy of delayed removal of row covers for suppressing bacterial wilt on muskmelon, and 2) compare costs and returns of delayed removal to conventional row cover timing and no row covers.

\section{Materials and Methods}

Six field trials were conducted at Iowa State University research farms in Gilbert and Muscatine (central and eastern Iowa respectively) in 2007, 2008, and 2009. Muskmelon seeds 
(cv. Athena) were planted in a greenhouse in 48-cell trays containing a potting mixture (40\% peat moss: 40\% prepared substrate (Sunshine mix SB300, Sun Gro Horticulture Canada Ltd, Vancouver, Canada): 20\% coarse perlite). Seedlings were transplanted to field plots on 5 June (Gilbert, 2007), 28 May (Muscatine, 2008), 11 June (Gilbert, 2008), 18 May (Gilbert, 2009), 21 May (Muscatine, 2009), and 22 June (Gilbert, 2009). Within 9-m-long, single-row subplots, plants were spaced every $0.6 \mathrm{~m}$ apart (15 plants per subplot) on black plastic mulch with drip irrigation; row centers were 2.1 to $2.4 \mathrm{~m}$ apart.

Immediately after transplanting, seedlings were covered with polypropylene spunbond row covers (AG-30, Agribon, Polymer Group Inc., Charlotte, NC) supported by wire hoops, and the covers were secured by burying the edges with soil. Treatments were: 1 ) row cover removed at anthesis (conventional timing of removal); 2) row cover ends opened at anthesis to enable pollinator access, then cover removed 10 days later; 3) bumble bee hive (Koppert Biological Systems Inc., Romulus, MI) inserted under one end of the row cover at anthesis, cover re-sealed, and then cover removed 10 days later; and 4) no row cover (control). Plots were arranged in four replications in a randomized complete block (2007) or latin square design (2008 and 2009).

Conventional fertilizer was incorporated during soil preparation; application rates were calculated based on crop nutrient requirements and soil test results. Herbicide and fungicide applications followed regional recommendations (11). No insecticide applications were made.

Bacterial wilt and cucumber beetle monitoring. After row cover removal, plants were assessed weekly until the start of harvest for incidence of bacterial wilt. A plant was considered wilted when symptoms appeared on one or more stems. Bacterial wilt was confirmed visually in the field by testing a subsample of symptomatic plants for the presence of bacterial ooze streaming from xylem tissues (26). Final percent wilt data was subjected to analysis of variance 
(PROC GLM; SAS Institute Inc., Version 9.1; Cary, NC). Area under disease progress curve (AUDPC) values were calculated from average wilt incidence estimates from row cover removal until first harvest. AUDPC values were analyzed in a one-way ANOVA. Striped and spotted adult cucumber beetle populations were monitored using non-baited AM Pherocon Yellow Sticky Traps (Trécé Inc., Adair, OK). Four traps were placed in each plot and captured adult beetles of each species were counted weekly from transplant until the end of the season.

Harvest data collection. During twice-weekly harvests, muskmelons were weighed and graded as marketable or non-marketable according to local direct-market standards. Data for marketable yield were subjected to analysis of variance (PROC GLM).

Economic analysis. A partial budget (9) was constructed to analyze costs and returns among treatments. Production costs were estimated using 2010 commercial prices of fertilizer, black plastic mulch, irrigation, seed, pesticide application, and labor. Direct costs of using row covers included the fabric, wire hoops, and labor for installation and removal. In the delayedremoval row cover treatments, additional costs of labor and bumble bee hives were added as appropriate. Revenue was calculated by extrapolating mean yield per subplot to a per-hectare basis, and multiplying by local wholesale and direct retail prices for muskmelon in central Iowa in 2010 (N. Howell, Iowa State University Horticulture Research Farm, Gilbert, IA., personal communication). The average weight of a marketable muskmelon (cv. Athena) was assumed to be $2.3 \mathrm{~kg}$ based on local market standards. Net returns were determined by subtracting production cost of each treatment from gross income on a per-hectare basis. Sensitivity analysis across treatments compared several scenarios with varying frequency of bacterial wilt occurrence: $0,5,10,15$, and 20 of 20 years. 


\section{Results}

Bacterial wilt incidence and yield. Bacterial wilt appeared in the three field trials held during 2007 and 2008 (Table 1). In these trials, use of row covers significantly $(P<0.05)$ suppressed bacterial wilt throughout the growing season. Delaying row cover removal by 10 days resulted in significantly less bacterial wilt at Gilbert in $2007(P<0.001)$ and Muscatine in $2008(P=0.004)$ than when row covers were removed at anthesis. In these two trials, marketable yield in the delayed-removal treatments was more than double that in the removal-at-anthesis treatment, and removing row covers at anthesis provided little or no advantage in either marketable yield or wilt suppression compared to the non-covered control. In the trial at Gilbert in 2008 ( $P=0.002)$, however, all row cover treatments suppressed bacterial wilt effectively and resulted in equivalent marketable yield that exceeded that in the non-covered control.

In 2009, bacterial wilt was absent in all three trials and row cover treatments had little impact on yield (Table 2). At Muscatine, however, marketable yield was significantly higher for the removal-at-anthesis treatment than for either the delayed-removal or control treatments.

Earliness. Impact of the row cover treatments on earliness (time from transplant until first mature fruit were harvested) varied among site years (Tables 1 and 2). The introduction of bumble bee hives under row covers did not increase earliness when compared to opening the ends at anthesis. In five of the six trials, removing row covers at anthesis enhanced earliness by 3 to 7 days compared to non-covered controls. At Muscatine in 2008, however, harvest of all row cover treatments began one week after the non-covered control. Delaying row cover removal by 10 days also tended to delay harvest by 1 to 7 days compared to the non-covered control. At Gilbert in 2007, however, harvest of row-covered treatments began 5 days earlier than in the control. 
Cucumber beetle monitoring. During the period from transplanting to row cover removal, cucumber beetle captures were minimal except for Gilbert in 2007 and 2008 (Figure 1). In the other four site-years, the number of captures began to increase only within 3 to 4 weeks of harvest. Both species were found in all site-years except for Muscatine in 2009, when only striped beetles were captured.

Economic analysis. To extrapolate to a commercial production situation, it was assumed that each row cover would span three rows. This system would substantially decrease labor costs compared to single-row plots used in the field experiment. A total of 25 bumble bee hives were estimated per hectare (http://www.koppert.com/pollination/vegetable-crops/crops/detail/melon/). Row covers raised production costs by approximately $45 \%$, primarily due to the cost of row covers, wire hoops, and labor for installation and removal (Table 3). Delaying row cover removal and opening row cover ends increased costs by a further $1 \%$ due to added labor, whereas inserting bumble bee hives raised costs by a total of $18 \%$ due to purchase of bumble bees and labor to install them under row covers.

Site years in which bacterial wilt was present (2007 and 2008) were contrasted to years in which no bacterial wilt was observed (2009).Value of a 2.3-kg, locally-grown muskmelon in central Iowa during 2007-2009 was assumed to be \$3 at wholesale and \$6 for direct-market retail. Melon prices exerted a strong impact on profitability in all site years (Table 3). For site years in which bacterial wilt occurred, average annual returns under both price scenarios were much higher for the delayed-removal strategies than for either the removal-at-anthesis or nocover controls. The wholesale-price scenario resulted in losses for the latter two treatments. In contrast, all treatments were profitable in 2009, when bacterial wilt was absent; productivity and 
profitability were much higher than in site years with bacterial wilt. All row cover strategies reduced projected returns in site years without bacterial wilt.

In the sensitivity analysis (Table 4), the highest annual returns occurred under the nodisease scenario for all treatments, and returns declined as the proportion of years with wilt outbreaks increased. When bacterial wilt was observed in none or five of the 20 years, average net returns in both delayed-removal treatments were slightly lower than for the removal-atanthesis and non-covered controls. When bacterial wilt occurred in 10 of 20 years, delayedremoval strategies began to yield higher returns than the controls. In this scenario, for example, the open-end treatment was more profitable than the controls at both fruit prices, whereas the bumble bee treatment was profitable only at the direct-market price. When bacterial wilt occurred in 15 or 20 of the 20 years, both delayed-removal treatments yielded the highest returns. When bacterial wilt occurred annually, removal-at-anthesis and non-covered control treatments generated negative annual returns at the wholesale price.

\section{Discussion}

Delayed-removal row cover strategies provided season-long protection of muskmelon against bacterial wilt. Using delayed-removal row covers to replace or reduce the need for insecticide sprays could be valuable for growers who lack access to effective insecticides against cucumber beetles, such as organic growers, and those who wish to reduce reliance on insecticides. In an organic trial in Pennsylvania, row covers significantly suppressed bacterial wilt incidence compared to the uncovered control (18). Although timing of removal did not seem to affect wilt suppression significantly, delaying row cover removal resulted in $13 \%$ less bacterial wilt and higher yield compared to row cover removal at anthesis (18). Therefore, even a 
$10 \%$ difference in suppressing the disease may salvage yield and reduce the need for insecticide applications.

The fact that adding 10 days to the row-covered period resulted in season-long suppression of bacterial wilt may be associated with reduction in both vector- and hostassociated risks. The highest risk of bacterial wilt transmission occurs during the spring when infested, overwintering cucumber beetles are strongly attracted to cucurbits due to the plants' high concentration of the secondary metabolite cucurbitacin $(3,10,13,14,31,38)$. The additional 10 days of protection could reduce disease risk if $i$ ) fewer first-generation cucumber beetles are present once covers are removed $(2,4,10,14,24)$, ii) plants advance to a growth stage that renders them less attractiveness to vectors $(13,37)$, iii) the older plants are more tolerant to infection $(2,29)$, or some combination of these factors. Clarification of the mechanism(s) associated with bacterial wilt risk reduction by delayed row cover removal awaits definitive studies of the ecology of E. tracheiphila transmission.

Efficacy of the delayed-removal strategy might be impacted by its timing during the growing season. For example, the delayed-removal treatments provided much better suppression of bacterial wilt when removal occurred by early July, but this difference was not evident when removal occurred 2 weeks later (Gilbert in 2008). Delaying the planting date may have eliminated the advantage of delayed-removal treatments compared to removal at anthesis. During the Gilbert 2008 trial, the relatively late occurrence of anthesis may have coincided with a decline in populations of infested overwintering cucumber beetles $(10,14,24,25)$, effectively minimizing the vector-associated risk. The absence of bacterial wilt in 2009 was assumed to stem from high mortality of overwintering cucumber beetles resulting from exceptionally low temperatures during the preceding winter (23). 
In addition to preventing bacterial wilt transmission, row covers may enhance yield by protecting plants against environmental extremes $(16,44)$. Plants protected from damaging wind or wind-driven rain might be less attractive to cucumber beetles (30). In temperate regions, plant development is accelerated by row covers mainly because they create a favorable microclimate for plant development $(41,42)$. Alternatively, when neither harsh weather conditions nor pestvectored disease pressure are present, row covers may not confer major yield improvement in cucurbits (34). Under certain weather conditions, row covers could even delay harvest by promoting excessive vegetative growth at the expense of fruit development (16). In the present study, removing row covers at anthesis generally enhanced earliness of yield by several days, whereas a 10-day delay in row cover removal delayed harvest by up to a week compared to the non-covered control. Reliably predicting the extent of harvest delays in muskmelon associated with delayed row-cover removal will require additional field trials over multiple sites and years.

The number of cucumber beetles captured on sticky cards during the period from transplanting to row cover removal was not consistently related to the level of bacterial wilt that developed in the trials. Although sticky card captures during this period were relatively high during two of the three site years when bacterial wilt appeared, and near zero in the wilt-free trials in 2009, the Muscatine trial in 2008 was an anomaly: row cover treatments suppressed wilt even though no beetles were collected until well after the row-covered period. This result casts doubt on the ability to interpret the risk of bacterial wilt transmission solely from weekly assessment of sticky-card captures. Additional methods, such as visual surveys of beetle activity in the crop, could provide a supplementary index of the risk of E. tracheiphila transmission (5).

Results of the partial budget analysis suggest that when bacterial wilt epidemics occurred, the delayed-removal row cover strategy would be likely to deliver more consistent returns than 
either the removal-at-anthesis row cover strategy or the non-covered control. Opening row cover ends at anthesis was generally more cost-effective than inserting bumble bee hives under the covers. Although the analysis did not consider melon-price advantages that could potentially occur from enhanced earliness of harvest, using bumble bees did not advance harvest compared to simply opening the row cover ends, so the substantial added expense and labor associated with using bumble bees did not appear to be advantageous.

Because bacterial wilt occurs sporadically in Iowa and other northern U.S. states, cost effectiveness of the delayed-removal strategy is likely to be impacted by the frequency of risk of bacterial wilt epidemics. The strategy was economically advantageous in situations when bacterial wilt occurred in $\geq 50 \%$ of growing seasons, but constrained returns when wilt was absent or less frequent. Models to predict overwintering survival of cucumber beetles, transmission risk of E. tracheiphila, and occurrence of bacterial wilt epidemics await development. For growers the advantage of using row covers will depend not only on the likelihood of disease occurrence but also on planting date, melon prices, availability of labor, and viability of effective alternative strategies to manage the disease.

\section{Acknowledgements}

We are grateful to Laura Jesse, Hank Taber, Vince Lawson, and Nick Howell for technical advice and assistance, and Mark Sigourney, Syngenta Corporation, for providing

muskmelon seeds. The project was funded by grants from the North Central Region IPM Center and U.S. Environmental Protection Agency Region VII Pesticide Environmental Stewardship Program (PESP). 


\section{Literature cited}

1. Alder, L. S., Hazzard, R. V. 2009. A comparison of perimeter trap crop varieties: effects on herbivory, pollination and yield in butternut squash. Environ. Entomol. 38: 207-215.

2. Brust, G. E.1997. Seasonal variation in percentage of striped cucumber beetles (Coleoptera: Chrysomelidae) that vector Erwinia tracheiphila. Environ. Entomol. 26: 580-584.

3. Brust, G. E.1997. Differential susceptibility of pumpkins to bacterial wilt related to plant growth stage and cultivar. Crop Prot. 16: 411-414.

4. Brust, G.E., Foster R.E. 1995. Semiochemical-based toxic baits for control of striped cucumber beetle (Coleoptera: Chrysomelidae) in cantaloupe. J. Econ. Entomol. 88: 112-116.

5. Brust, G.E., Foster R.E. 1999. New economic threshold for striped cucumber beetle (Coleoptera: Chrysomelidae in cantaloupe in the Midwest. J. Econ. Entomol. 92: 936-940.

6. Brust, G.E., Rane, K.K. 1995. Differential occurrence of bacterial wilt in muskmelon due to preferential striped cucumber beetle feeding. HortScience. 30:1043-1045.

7. Bextine, B., Wayadande, A., Bruton, B. D., Pair, S. D., Mitchell, F., Fletcher, J.2001. Effect of insect exclusion on the incidence of yellow vine disease and of the associated bacterium in squash. Plant Dis. 85: 875-878.

8. Burkness, E.C., Hutchison W.D.1998. Development and validation of a fixed-precision sampling plan for estimating striped cucumber beetle (Coleoptera:Chrysomelidae) density in cucurbits. Pest management and sampling. 27:178-183.

9. Calkins, P.H.; Dipietre, D.D. 1983. Farm Business management: successful decisions in a changing environment. MacMillan and Company. 442 pp. New York, USA. 
10. deMackiewicz, D., Gildow, F.E., Blua, M., Fleischer, S.J., and Lukezic, F.L. 1998.

Herbaceous weeds are not economically important reservoirs of Erwinia tracheiphila. Plant Dis. 82:521-529.

11. Egel, D., Foster, R., Maynard, E., Weinzierl, R., Babadoost, M., Taber, H., Bauernfeind, R., Carey, T., Kennelly, M., Hutchinson, B., Gu, S. 2007. Midwest Vegetable Production Guide for Commercial Growers 2007. 164 pp.

12. Ellers-Kirk, C.D., Fleischer, S.J., Snyder, R.H., Lynch, J.P. 2000. Potential of entomopathogenic nematodes for biological control of Acalymma vittatum (Coleoptera:Chrysomelidae) in cucumbers grown in conventional and organic soil management systems. J. Econ. Entomol. 93:605-612.

13. Ferguson, J.E., Metcalf, E.R., Metcalf, R.L., Rhodes, A.M. 1983. Influence of cucurbitacin content in cotyledons of Cucurbitaceae cultivars upon feeding behavior in Diabrotica beetle. J. Econ. Entomol. 76:47-51.

14. Fleischer, S.J., deMackiewicz, D., Gildow, F.E., and Lukezic, F.L. 1999. Serological estimates of the seasonal dynamics of Erwinia tracheiphila in Acalymma vittata. Environ. Entomol. 28:470-476.

15. Fleischer, S. J., Orzolek, M. D., deMackiewicz, D., Otjen, L. 1998. Imidacloprid effects on Acalymma vittata (Coleoptera: Chrysomelidae) and bacterial wilt in cantaloupe. J. Econ. Entomol. 940-949.

16. Gaye, M.M., Maurer, A.R., and Seywerd, F.M. 1991. Honey bees placed under row covers affect muskmelon yield and quality. Sci. Hort. 47:59-66.

17. Gould, G.E. 1944.The Biology and Control of the Striped Cucumber Beetle. Purdue Univ. Agric. Exp. Stn. Bull. No. 490: p. 28. 
18. Hernández, E., Sánchez, E. 2010. Compost, rhizobacteria, and row covers: a way to manage nutrients and pests in organic production. Penn State Sustainable Agriculture Newsletter. May 2010 (http://agsci.psu.edu/susag/newsletter/May-2010/1-organic-cucurbit).

19. Hoffman, M. P.; Kirkwyland, J. J.; Smith, R. F. and Long, R. F. (1996), Field tests with kairomone-baited traps for cucumber beetles and corn rootworms in cucurbits. Environ. Entomol. 25: 1172-1181.

20. Ibarra, L., J. Flores, J.C. Díaz-Pérez. 2001. Growth and yield of muskmelon in response to plastic mulch and row covers. Sci. Hort. 87:139-145.

21. Jenni, S.1996. Predicting yield and development of Muskmelon (Cucumis melo L.) under mulch and row cover management. Department of Plant Science, McGill University, Montreal, Canada.

22. Jesse, L., Gleason, M.L., Owens, A., Batzer, J., Lewis, D., Taber, H. 2007. Use of bumble bees to extend duration of row covers on muskmelon in Iowa. Abstract, Annual meeting of Entomological Society of America, San Diego, CA, December 2007.

23. Koch, R. L.; Carrillo, M. A.; Burkness, E. C.; Hutchison, W. D. 2005. Observations on the overwintering potential of the striped cucumber beetle (Coleoptera: Chrysomelidae) in Southern Minnesota. Gt. Lakes Entomol. 38: 23-29.

24. Lam, W.F. 2007. An alternative sampling technique for cucumber beetles (Colepotera: Chrysomelidae) and diurnal beetle activity on muskmelon. J. Econ. Entomol. 100:823-829.

25. Latin, R.X. 1993. Diseases and pests of muskmelons and watermelons. Bulletin BP-44, Purdue University Extension.

26. Latin, R.X. October 2000. APSnet Features. Bacterial Wilt. (http://www.apsnet.org/publications/apsnetfeatures/Pages/BacterialWilt.aspx_) 
27. Leach, J. G. 1964. Observations on cucumber beetles as vectors of cucurbit wilt. Phytopathology 54: 606-607.

28. Lewis, P. A., Lampman, R. L., Metcalf, R. L.1990. Kairomonal attractants for Acalymma vittatum (Coleoptera: Chrysomelidae). Environ. Entomol. 19: 8-14.

29. Lukezic, F. L., Sackett, W. M., Fleischer S. J., Orzolek, M. D., Gildow, F. E. 1996. Influence of the concentration of Erwinia tracheiphila cells on the development of wilt symptoms in field-grown cucumber and cantaloupe plants. Phytopathology (Abstr.) 86: S123.

30. Metcalf, R.L., Metcalf, R.A., Rhodes, A.M.1980. Cucurbitacins as kairomones for diabroticite beetles. Proc. Natl. Acad. Sci. 77:49-3769-3772.

31. Mitchell, R.F., Hanks, L.M. 2009. Insect frass as a pathway for transmission of bacterial wilt of cucurbits. Environ. Entomol. 38: 395-403.

32. Mueller, D.S., Gleason, M.L., Sisson, A.J., and Massman, J.M. 2006. Effect of row covers on suppression of bacterial wilt of muskmelon in Iowa. Plant Health Progress. doi: 10.1094/PHP-2006-1020-02-RS.

33. Nagent, P.E., Cuthbert, F.P., Hoffman, J.C. 1984. Two genes for cucumber beetle resistance in muskmelon. J. Amer.Soc.Hort.Sci.109:756-759.

34. Nair, A., Ngouajio, M.2010. Integrating row covers and soil amendments for organic cucumber production: implications on crop growth, yield, and microclimate. HortScience 45: 566-574.

35. Natwick, E. T., Laemmlen, F. F.1993. Protection from phytophagous insects and virus vectors in honeydew melons using row covers. Fla. Entomol. 76: 120-126. 
36. Orozco-Santos, M.; Perez-Zamora, O.; Lopez-Arriaga, O.1995. Floating row cover and transparent mulch to reduce insect populations, virus diseases and increase yield in cantaloupe. Fla. Entomol. 78 (3): 493-501.

37. Pair, S.D. 1997. Evaluation of systemically treated squash trap plants and attracticidal baits for early-season control of striped and spotted cucumber beetles (Coleoptera: Chrysomelidae) and squash bug (Hemiptera: Coreidae) in cucurbit crops. J. Econ. Entomol. . 90: 1307-1314.

38. Rand, F. V., Cash, L.1920. Some insect relations of Bacillus tracheiphilus Erw. Sm. Phytopathology 10: 133-140.

39. Rand, F. V., Enlows, E.M.A. 1916. Transmission and control of bacterial wilt of cucurbits. J. Agric. Res. 6: 417-434.

40. Sherf, A.F., MacNabb, A.A. 1986. Cucurbits, p. 307-311 in Vegetable disease and their control. Wiley, New York.

41. Soltani, N., Anderson, J.L., Hamson, A.R.1995. Growth analysis of watermelon plants grown with mulches and row covers. J. Amer. Soc. Hort. Sci. 120(6):1001-1009.

42. Taber, H.G. 1993. Early muskmelon production with wavelength-selective and clear plastic mulches. HortTechnology 3:78-80.

43. Vaissiere, B.E., and Froissart, R.1996. Pest management and pollination of cantaloupes grown under spunbonded row covers in West Africa. J. of Hortic.Sci.71:755-766.

44. Wells, O. S.; Loy, J. B.1985. Intensive vegetable production with row covers. HortScience 20: 822-826.

45. Wolfe, D. W, Albright, Wyland, L.D. 1989. Modeling row cover effects on microclimate and yield: I. Growth response of tomato and cucumber. J. Amer. Soc. Hort. Sci. 114(4):562568. 
Tables

Table 1. Influence of row cover treatments on bacterial wilt incidence and yield in muskmelons in three site-years, Iowa, USA.

\begin{tabular}{|c|c|c|c|c|c|c|}
\hline \multirow[b]{2}{*}{ Year } & \multirow[b]{2}{*}{ Location } & \multirow[b]{2}{*}{ Treatment } & \multicolumn{4}{|c|}{ Wilt incidence Mean marketable } \\
\hline & & & AUDPC $^{w}$ & $(\%)^{x}$ & yield $(\mathbf{k g})^{\mathrm{y}}$ & Earliness $^{\mathrm{z}}$ \\
\hline \multirow{5}{*}{2007} & \multirow{5}{*}{ Gilbert } & Removed at anthesis $^{\mathbf{s}}$ & $583.3 \mathrm{~b}$ & $58.3 \mathrm{a}$ & $10.9 \mathrm{~b}$ & 57 \\
\hline & & Delayed removal; ends opened ${ }^{\text {t }}$ & $87.5 \mathrm{c}$ & $5.0 \mathrm{~b}$ & 23.9 a & 57 \\
\hline & & Delayed removal; bumblebees $\mathbf{u}$ & $58.3 \mathrm{c}$ & $6.7 \mathrm{~b}$ & $23.2 \mathrm{a}$ & 57 \\
\hline & & Control & 1738.3 a & $75.0 \mathrm{a}$ & $2.8 \mathrm{c}$ & 62 \\
\hline & & $\operatorname{LSD}^{v}$ & 265.7 & 17.4 & 3.2 & -- \\
\hline \multirow{5}{*}{2008} & \multirow{5}{*}{ Gilbert } & Removed at anthesis $^{\mathbf{s}}$ & $5.8 \mathrm{~b}$ & $1.7 \mathrm{~b}$ & $31.5 \mathrm{a}$ & 97 \\
\hline & & Delayed removal; ends opened ${ }^{\text {t }}$ & $0.0 \mathrm{~b}$ & $0.0 \mathrm{~b}$ & $34.8 \mathrm{a}$ & 97 \\
\hline & & Delayed removal; bumblebees $\mathbf{u}$ & $29.2 \mathrm{~b}$ & $8.3 \mathrm{~b}$ & $42.9 \mathrm{a}$ & 97 \\
\hline & & Control & 1405.8 a & 60.0 a & $8.0 \mathrm{~b}$ & 90 \\
\hline & & $\mathrm{LSD}^{\mathrm{v}}$ & 344.3 & 22.1 & 14.7 & -- \\
\hline \multirow{5}{*}{2008} & \multirow{5}{*}{ Muscatine } & Removed at anthesis $^{\mathbf{s}}$ & $600.8 \mathrm{a}$ & $55.0 \mathrm{a}$ & $24.3 \mathrm{~b}$ & 64 \\
\hline & & Delayed removal; ends opened ${ }^{\mathbf{t}}$ & $134.2 \mathrm{~b}$ & $18.3 \mathrm{~b}$ & $49.4 \mathrm{a}$ & 64 \\
\hline & & Delayed removal; bumblebees u & $64.2 \mathrm{~b}$ & $11.7 \mathrm{~b}$ & $52.1 \mathrm{a}$ & 64 \\
\hline & & Control & $554.2 \mathrm{a}$ & 53.3 a & $16.8 \mathrm{~b}$ & 57 \\
\hline & & $\operatorname{LSD}^{v}$ & 365.8 & 20.7 & 14.3 & -- \\
\hline
\end{tabular}


${ }^{\mathrm{s}}$ Row covers were removed when first flowers appeared.

${ }^{\mathrm{t}}$ Ends of row covers were opened at anthesis; row covers were removed 10 days later.

${ }^{\mathrm{u}}$ A bumblebee hive (Koppert Biological Systems Inc., Romulus, MI) was inserted under one end of the row cover, and the row cover was re-sealed. Row cover was removed 10 days later.

${ }^{\mathrm{v}}$ Means followed by the same letter are not significantly different within row (Least Significant Difference; $P<0.05$ ).

${ }^{\mathrm{w}}$ Area under disease progress curve

${ }^{\mathrm{x}}$ Final wilt incidence evaluation before first harvest

${ }^{\mathrm{y}}$ Mean marketable weight per treatment (average of four 9-m-long, single-row subplots).

${ }^{\mathrm{z}}$ Days between transplant and first harvest 
Table 2. Influence of row cover treatments on mean marketable yield in muskmelons in three sites in 2009, Iowa, USA.

\begin{tabular}{|c|c|c|c|}
\hline \multirow[b]{2}{*}{ Location } & \multirow[b]{2}{*}{ Treatment } & \multicolumn{2}{|c|}{ Mean marketable } \\
\hline & & yield (kg) ${ }^{y}$ & Earliness ${ }^{z}$ \\
\hline \multirow{5}{*}{ Gilbert $^{\text {s }}$} & Removed at anthesis ${ }^{\mathbf{u}}$ & $116.4 \mathrm{a}$ & 77 \\
\hline & Delayed removal; ends opened ${ }^{\mathbf{v}}$ & $113.4 \mathrm{a}$ & 80 \\
\hline & Delayed removal; bumblebees ${ }^{\mathbf{w}}$ & $109.0 \mathrm{a}$ & 82 \\
\hline & Control & $131.0 \mathrm{a}$ & 79 \\
\hline & $\operatorname{LSD}^{x}$ & NS & -- \\
\hline \multirow{5}{*}{ Gilbert $^{t}$} & Removed at anthesis $\mathbf{u}$ & $103.6 \mathrm{a}$ & 62 \\
\hline & Delayed removal; ends opened ${ }^{\mathbf{v}}$ & $105.2 \mathrm{a}$ & 70 \\
\hline & Delayed removal; bumblebees ${ }^{\mathbf{w}}$ & $122.5 \mathrm{a}$ & 71 \\
\hline & Control & $109.3 \mathrm{a}$ & 67 \\
\hline & $\operatorname{LSD}^{x}$ & NS & -- \\
\hline \multirow{5}{*}{ Muscatine } & Removed at anthesis ${ }^{\mathbf{u}}$ & $83.8 \mathrm{a}$ & 77 \\
\hline & Delayed removal; ends opened ${ }^{\mathbf{v}}$ & $68.6 \mathrm{ab}$ & 83 \\
\hline & Delayed removal; bumblebees ${ }^{\mathbf{w}}$ & $60.8 \mathrm{~b}$ & 82 \\
\hline & Control & $67.3 \mathrm{~b}$ & 80 \\
\hline & $\operatorname{LSD}^{x}$ & 15.4 & -- \\
\hline
\end{tabular}


${ }^{\mathrm{s}}$ Transplant: May 18, 2009. Anthesis: June 17, 2009

${ }^{\mathrm{t}}$ Transplant: June 22, 2009. Anthesis: July 13, 2009

${ }^{\mathrm{u}}$ Row covers were removed when first flowers appeared.

${ }^{\mathrm{v}}$ Ends of row covers were opened at anthesis; row covers were removed 10 days later.

${ }^{\mathrm{w}}$ A bumblebee hive (Koppert Biological Systems Inc., Romulus, MI) was inserted under one end of the row cover, and the row cover was re-sealed. Row cover was removed 10 days later.

${ }^{\mathrm{x}}$ Means followed by the same letter are not significantly different within row (Least Significant Difference; $P<0.05)$.

${ }^{\mathrm{y}}$ Mean marketable weight per treatment (average of four 9-m-long, single-row subplots).

${ }^{\mathrm{z}}$ Days between transplant and first harvest 
Table 3. Partial budget showing costs and analysis of net returns ${ }^{\mathrm{r}}$ per hectare of muskmelon in two disease-pressure melonprice scenarios.

\begin{tabular}{|c|c|c|c|c|c|}
\hline \multirow[b]{2}{*}{ Treatment } & \multirow[b]{2}{*}{ Cost $^{v}$} & \multicolumn{2}{|c|}{ Bacterial wilt ${ }^{\mathrm{y}}$} & \multicolumn{2}{|c|}{ No bacterial wilt ${ }^{z}$} \\
\hline & & \$3/melon w & $\$ 6 /$ melon $^{x}$ & \$3/melon & \$6/melon \\
\hline Removed at anthesis $^{\mathbf{s}}$ & $\$ 16,095$ & $-\$ 926$ & $\$ 14,243$ & $\$ 52,994$ & $\$ 122,082$ \\
\hline Delayed removal; ends opened ${ }^{\mathbf{t}}$ & $\$ 16,193$ & $\$ 8,390$ & $\$ 32,974$ & $\$ 49,120$ & $\$ 114,433$ \\
\hline Delayed removal; bumblebees ${ }^{\mathbf{u}}$ & $\$ 19,627$ & $\$ 6,100$ & $\$ 32,981$ & $\$ 45,693$ & $\$ 112,166$ \\
\hline Control & $\$ 11,063$ & $-\$ 4,787$ & $\$ 1,490$ & $\$ 58,889$ & $\$ 128,842$ \\
\hline
\end{tabular}


${ }^{\mathrm{r}}$ Remainder from subtraction of production costs of each treatment from gross income. ${ }^{\mathrm{s}}$ Row covers were removed when first flowers appeared.

${ }^{\mathrm{t}}$ Ends of row covers were opened at anthesis; row covers were removed 10 days later.

u A bumblebee hive (Koppert Biological Systems Inc., Romulus, MI) was inserted under one end of the row cover, and the row cover was re-sealed. Row cover was removed 10 days later.

${ }^{\mathrm{v}}$ Production costs associated with the establishment and maintenance of one hectare of muskmelon using each row cover treatment.

${ }^{\mathrm{w}}$ Wholesale price estimated for a 2.3-kg locally-grown muskmelon in 2007-2009 in central Iowa.

${ }^{\mathrm{x}}$ Retail price estimated for a 2.3-kg locally-grown muskmelon in 2007-2009 in central Iowa.

${ }^{\mathrm{y}}$ Mean net returns estimated from 2007 and 2008 field trial results where bacterial wilt was observed.

${ }^{\mathrm{z}}$ Mean net returns estimated from 2009 field trial results where no bacterial wilt was observed. 
Table 4. Sensitivity analysis comparing average annual net returns in five bacterial wilt incidence scenarios during 20 years of production.

\begin{tabular}{|c|c|c|c|c|c|}
\hline \multirow[b]{2}{*}{ Treatment } & \multicolumn{5}{|c|}{ Number of years with bacterial wilt in 20 years ${ }^{x}$} \\
\hline & $\mathbf{0}$ & 5 & 10 & 15 & 20 \\
\hline & \multicolumn{5}{|c|}{ Net returns at $\$ 3 /$ melon $^{y}$} \\
\hline Removed at anthesis ${ }^{\mathbf{u}}$ & $\$ 52,994$ & $\$ 39,514$ & $\$ 26,034$ & $\$ 12,554$ & $-\$ 926$ \\
\hline Delayed removal; ends opened ${ }^{\mathbf{v}}$ & $\$ 49,120$ & $\$ 38,938$ & $\$ 28,755$ & $\$ 18,573$ & $\$ 8,390$ \\
\hline Delayed removal; bumblebees ${ }^{\text {w }}$ & $\$ 45,693$ & $\$ 35,795$ & $\$ 25,897$ & $\$ 15,998$ & $\$ 6,100$ \\
\hline \multirow[t]{2}{*}{ Control } & $\$ 58,889$ & $\$ 42,970$ & $\$ 27,051$ & $\$ 11,132$ & $-\$ 4,787$ \\
\hline & \multicolumn{5}{|c|}{ Net returns at $\$ 6 /$ melon $^{z}$} \\
\hline Removed at anthesis ${ }^{\mathbf{u}}$ & $\$ 122,082$ & $\$ 95,122$ & $\$ 68,162$ & $\$ 41,202$ & $\$ 14,243$ \\
\hline Delayed removal; ends opened ${ }^{\mathbf{v}}$ & $\$ 114,433$ & $\$ 94,068$ & $\$ 73,703$ & $\$ 53,339$ & $\$ 32,974$ \\
\hline Delayed removal; bumblebees ${ }^{\text {w }}$ & $\$ 112,166$ & $\$ 92,370$ & $\$ 72,573$ & $\$ 52,777$ & $\$ 32,981$ \\
\hline Control & $\$ 128,842$ & $\$ 97,004$ & $\$ 65,166$ & $\$ 33,328$ & $\$ 1,490$ \\
\hline
\end{tabular}


${ }^{\mathrm{u}}$ Row covers were removed when first flowers appeared.

${ }^{\mathrm{v}}$ Ends of row covers were opened at anthesis; row covers were removed 10 days later.

${ }^{\text {w }}$ A bumblebee hive (Koppert Biological Systems Inc., Romulus, MI) was inserted under one end of the row cover, and the row cover was re-sealed. Row cover was removed 10 days later.

${ }^{\mathrm{x}}$ Simulation of bacterial wilt incidence in 20 years of muskmelon production.

${ }^{\mathrm{y}}$ Net returns per hectare per year estimated based on a \$3 wholesale price for a 2.3-kg muskmelon.

${ }^{\mathrm{z}}$ Net returns per hectare per year estimated based on a $\$ 6$ retail direct-market price for a 2.3-kg muskmelon. 


\section{Figure}

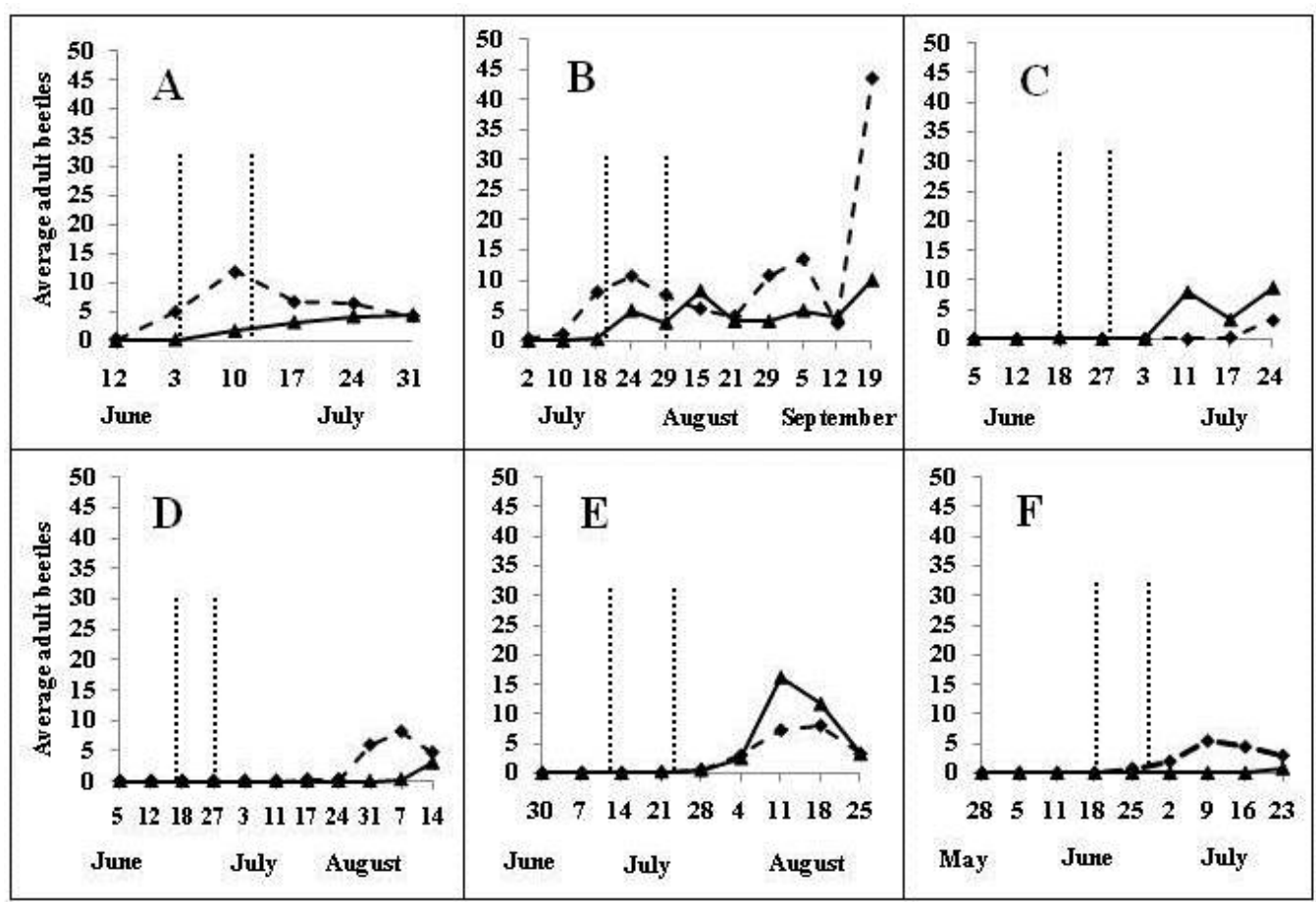

Figure 1. Striped $(-\bullet)$ and spotted $(-\boldsymbol{})$ cucumber beetles captured on sticky traps from transplant until first harvest in six row cover trials in Iowa, USA: Gilbert, 2007 (A); Gilbert, 2008 (B); Muscatine, 2008 (C); Gilbert transplant: May 18, 2009 (D);

Gilbert, transplant: June 22, 2009 (E); Muscatine, 2009 (F). In each graph vertical lines indicate date of anthesis (left) and 10 days after anthesis (right). 


\title{
CHAPTER 3
}

\section{EPIPHYTIC SURVIVAL OF ERWINIA TRACHEIPHILA ON MUSKMELON (CUCUMIS MELO L.)}

A paper published in Plant Disease (2012, 96:62-66)

E. Saalau-Rojas and M.L. Gleason

\begin{abstract}
Erwinia tracheiphila, the causal agent of bacterial wilt of cucurbits, is transmitted by striped (Acalymma vittatum (F.)) and spotted (Diabrotica undecimpunctata howardi (Barber)) cucumber beetles. Transmission occurs when infested frass with $E$. tracheiphila is deposited on plant surfaces with fresh feeding wounds. However, it is unclear whether the pathogen can survive as an epiphyte on leaves. Experiments were conducted in controlled environments to monitor E. tracheiphila survival on muskmelon (Cucumis melo L.) leaves under various temperature and moisture conditions. In the first experiment, muskmelon seedlings that had been spray-inoculated with a rifampicinresistant strain of E. tracheiphila were incubated at $10,15,20,25,30$, or $35^{\circ} \mathrm{C}\left( \pm 2^{\circ} \mathrm{C}\right)$ at $\geq 95 \% \mathrm{RH}$ and E. tracheiphila populations were monitored for $72 \mathrm{~h}$. In the second experiment, E. tracheiphila was monitored during alternating 12-h wet and dry periods, or continuous wet or dry conditions for $48 \mathrm{~h}$ at $20^{\circ} \mathrm{C}$. Survival of E. tracheiphila on wet muskmelon leaves depended on temperature $(P<0.01)$, with the greatest survival at 10 and $15^{\circ} \mathrm{C}$ and least at 30 and $35^{\circ} \mathrm{C}$. Leaf wetness also impacted survival; an initial 12-h dry period resulted in a 1,000-to 10,000-fold reduction in population size, followed by stabilization of the surviving population. These results demonstrate that E. tracheiphila
\end{abstract}


can survive on muskmelon leaves under a wide range of environmental conditions, suggesting that epiphytic populations might serve as a reservoir of inoculum for infections.

\section{Introduction}

Bacterial wilt caused by Erwinia tracheiphila is a major challenge for cucurbit growers in the eastern half of the United States $(13,26,27)$. Bacterial wilt impacts all cucurbit crops except watermelon. In muskmelon (Cucumis melo L.), for example, yield losses can be as high as $80 \%$ (26). The U.S. is one of the major producers of cantaloupe and melon (Cucumis spp.) worldwide, with a farm gate value of approximately $\$ 400$ million in 2009 (34).

Striped (Acalymma vittatum (F.)) and spotted (Diabrotica undecimpunctata howardi (Barber)) cucumber beetles transmit E. tracheiphila (15, 32, 37). The pathogen overwinters in adult beetles $(15,16,36)$. Transmission occurs when adults feed on plants; inoculum from infested frass enters freshly wounded tissues $(6,9,25,28,32,37)$ on leaves, stems, or nectaries of flowers (41). Bacteria enter the vascular system via these openings, multiply, and produce exopolysaccharides, which eventually block water flow to the rest of the plant (41). Symptoms include wilting of leaves and vines followed by collapse of the entire plant.

Management strategies against bacterial wilt focus primarily on controlling the vectors by insecticide applications $(7,8,13,14)$. However, this dependency on insecticides can create hazards for growers, consumers, pollinators, and the environment 
$(7,14,18,21)$. Alternative strategies such as row covers $(22,32,40)$, perimeter trap crops $(1,12,35)$, and kairomonal baits $(19,30)$ can reduce the risk of bacterial wilt, but they can be labor intensive and require further validation before they can be used reliably by growers.

Lack of understanding of E. tracheiphila ecology and epidemiology is a barrier to developing effective ecologically based alternatives for bacterial wilt management. One reason for this poor understanding is that E. tracheiphila is difficult to isolate and maintain in culture. Unlike several other important Erwinia spp. phytopathogens, E. tracheiphila grows slowly in culture and can rapidly lose viability (10). As a result, the potential role of epiphytic populations of E. tracheiphila in the disease cycle remains largely unexplored. Epiphytic populations can serve as primary inoculum for development of epidemics in many bacterial pathosystems $(4,17,38)$, and characterizing the environmental biology of the epiphytic phase has facilitated the development of more effective management strategies. For example, monitoring epiphytic populations of the fire blight pathogen Erwinia amylovora has been essential for determining the risk of disease epidemics, improving biological control methods, and timing antibiotic applications (23, 24, 42, 45).

Experiments by Brust (9) provided indirect evidence that E. tracheiphila might have an epiphytic phase on cucurbit crops. These experiments suggested that $E$. tracheiphila could survive for up to 6 hours on muskmelon leaf surfaces, and that these populations could infect plants after leaves were wounded. Mitchell and Hanks (32) confirmed that E. tracheiphila could survive in beetle frass and retain viability as 
inoculum for up to 24 hours after the bacterium was ingested by striped cucumber beetles.

The impact of environmental conditions on epiphytic survival of E. tracheiphila is also poorly understood. It is reasonable to assume E. tracheiphila could be dispersed from frass deposits to other sites on leaf surfaces by rain or dew, potentially resulting in infection via wounds. Moist weather conditions may also favor infection by $E$. tracheiphila (37), as suggested by the common association of moist conditions with bacterial wilt development (44). The purpose of the present study was to evaluate whether E. tracheiphila survives on muskmelon leaves, and to assess how survival is influenced by temperature and fluctuating moisture conditions.

\section{Materials and Methods}

Plant growth conditions. Muskmelon seeds (cv. Athena) were planted in 233$\mathrm{cm}^{3}$ pots (Nu-Pot 3; Summit Plastic Co., Akron, OH; 40\% peat moss, 40\% prepared substrate [Sunshine Mix SB300, Sun Gro Horticulture Canada Ltd., Vancouver, Canada], and $20 \%$ coarse perlite). They were incubated for 12 to 15 days at $25^{\circ} \mathrm{C}$ under a 12-h light/12-h dark regime in a growth chamber (Model PGW36, Conviron, Winnipeg, Canada) until unfolding of the first true leaf. After emergence, seedlings were thinned to one per pot.

Bacterial strains and growth conditions. A naturally occurring rifampicinresistant strain of Erwinia tracheiphila, SCR3, was isolated from a wilting muskmelon plant in Iowa in 2009 (39). Colonies that resembled E. tracheiphila in morphology (10) 
were confirmed positive by PCR using E. tracheiphila-specific primers ETC1and ETC2 (31). Colonies were selected for rifampicin resistance $(75 \mu \mathrm{g} / \mathrm{ml})$ and stored at $-80^{\circ} \mathrm{C}$ in Luria Bertaini (LB) broth containing 25\% glycerol (39). In order to fulfill Koch’s postulates, 2-week-old muskmelon plants were puncture-inoculated with SCR3 strain. Bacterial colonies were suspended in sterile $10 \mathrm{mM}$ phosphate buffered saline (PBS) solution (pH 7.4) and the concentration was adjusted to $10^{8} \mathrm{CFU} / \mathrm{ml}$. A $100-\mu l$ aliquot of the suspension was spread on the first true leaf of seedlings and leaves were punctured using a pin frog. Wilt symptoms were assessed and the strain was re-isolated from symptomatic plants (39).

Inoculum preparation. Strain SCR3 was recovered from $-80^{\circ} \mathrm{C} 1$ week prior to inoculum preparation, streaked onto nutrient agar peptone (NAP) plates amended with $75 \mu \mathrm{g} / \mathrm{ml}$ of rifampicin, and incubated at $26^{\circ} \mathrm{C}$ in darkness. Cultures were incubated for 4 days, then re-streaked onto fresh NAP plates 3 days before inoculum preparation. Inoculum was prepared by suspending strain SCR3, grown on NAP, in 10 mM PBS solution (pH 7.4) and adjusting the concentration to approximately $10^{8} \mathrm{CFU}$ per ml. Cell concentrations were calculated based on optical density in a spectrophotometer at 540 nm according to a standard curve for E. tracheiphila.

Influence of temperature on epiphytic survival. Twelve pots, each containing one muskmelon plant, were evenly spaced in each of four 25-pot trays (Nu-tray 3-25; Summit Plastic Co., Akron, OH). Plants with a fully unfolded first true leaf were sprayinoculated until runoff with inoculum using a hand-trigger sprayer (Model 916CN, Contico International, St. Louis, MO). Immediately after inoculation, trays were placed 
in dew chambers (Model I60DL, Percival International, Perry, IA) and incubated for 72 hours at $10,15,20,25,30$, or $35^{\circ} \mathrm{C}\left( \pm 2^{\circ} \mathrm{C}\right)$ and a 12 -h light/12-h dark regime under conditions (> 95\% RH) conducive to dew formation. The experimental design was a split-plot, randomized complete block in which temperature was the whole-plot treatment randomly assigned to a dew chamber in a run, and sampling time was the subplot treatment randomly assigned to a leaf in a tray. Temperature and RH were recorded hourly using WatchDog Data Loggers (Model 150, Spectrum Technologies, Plainfield, IL). At each sampling time, two arbitrarily selected leaves, each from a different plant, were excised from each tray. A total of eight leaves per sampling time were removed at 0, 12, 24, 36, 48, and $72 \mathrm{~h}$ after inoculation. Each excised leaf was immersed in $20 \mathrm{ml}$ of 0.1M PBS $(\mathrm{pH} 7.4+0.01 \%$ peptone $\mathrm{w} / \mathrm{v})$ in sterile 50 -ml polypropylene centrifuge tubes (Corning Inc., Corning, NY), then sonicated (Model Branson 200, Branson Ultrasonic Corp., Danbury, CT) for 7 min and mixed by vortexing for 15 s. Five-fold dilutions of each leaf washing were plated onto NAP amended with $75 \mu \mathrm{g} / \mathrm{ml}$ of rifampicin and 100 $\mu \mathrm{g} / \mathrm{ml}$ of cycloheximide. Leaves were removed from the centrifuge tubes and allowed to air-dry on paper towels for 15 min before weighing. After 5 days at $26^{\circ} \mathrm{C}$ in darkness, colonies of E. tracheiphila were counted and expressed as CFU per gram of fresh leaf weight. The experiment was performed twice.

Epiphytic survival during intermittent wet and dry periods. To determine epiphytic survival of E. tracheiphila under wetting and drying conditions resembling those that occur under field conditions, plants were spray-inoculated as previously described and maintained at $20^{\circ} \mathrm{C}$ throughout the experiment. In order to create different 
wetness regimes, plants were incubated for $48 \mathrm{~h}$ in a dew chamber $(>95 \% \mathrm{RH})$ in darkness or a growth chamber $(<30 \% \mathrm{RH})$ in the light as follows: continuous wet or dry conditions, 12-h wet periods alternated with 12-h dry periods, or 12-h dry periods alternated with 12-h wet periods. The experimental design was a split-plot, randomized complete block in which wetness regime was the whole-plot treatment randomly assigned to a chamber in a run, and sampling time was the sub-plot treatment randomly assigned to a leaf in a tray. A total of eight leaves were excised at each sampling time (0, 12, 24, and $48 \mathrm{~h}$ after inoculation). After sonication and vortexing, E. tracheiphila populations were enumerated as described above. The experiment was performed twice.

Statistical analysis. In each experiment, colony counts were normalized to CFU per gram of fresh leaf weight by $\log _{10}$ transformation. For both experiments, transformed data were compared by analysis of variance (ANOVA) using PROC MIXED (SAS Institute Inc., Version 9.1; Cary, NC). The whole-plot treatment (temperature or wetness regime) was tested against the whole plot error, run*temperature, the split plot treatment, and sampling time, and interactions were tested against the residual error. Area under the curve (AUC) values were estimated from average populations $\left(\log _{10} \mathrm{CFU} / \mathrm{g}\right.$ fresh weight) determined at each sampling time in each experiment. AUC values were analyzed in a one-way ANOVA using PROC GLM (SAS Institute Inc.).

\section{Results}

Impact of temperature on epiphytic survival. Survival of E. tracheiphila on muskmelon leaves was impacted by temperature (Table 1). By $12 \mathrm{~h}$ after inoculation, 
population size had decreased significantly at all temperatures (Fig. 1) $(P<0.01)$. There was no significant change in population size at either 10 or $15^{\circ} \mathrm{C}$ between 12 and $72 \mathrm{~h}$ after inoculation. The population sizes at the mid-range temperatures plateaued after 12 $\mathrm{h}$ but then decreased significantly by $36 \mathrm{~h}\left(25^{\circ} \mathrm{C}\right)$ and $72 \mathrm{~h}\left(20^{\circ} \mathrm{C}\right)$. E. tracheiphila populations declined rapidly and continuously for $24 \mathrm{~h}$ at $30^{\circ} \mathrm{C}$ and for up to $72 \mathrm{~h}$ at $35^{\circ} \mathrm{C}$. Values of AUC indicated that survival at 10 and $15^{\circ} \mathrm{C}$ exceeded that at $20,25,30$, and $35^{\circ} \mathrm{C}$, whereas AUC values at mid-range temperatures were similar to each other (Table 2).

Impact of intermittent wet and dry periods on epiphytic survival. Survival of E. tracheiphila on muskmelon leaves was impacted by wetness regime (Table 1). The presence or absence of wetness on leaves significantly impacted survival during the first $12 \mathrm{~h}$ after inoculation (Fig.2). Survival was significantly higher under continuous wet conditions and lowest when plants were initially exposed to dry conditions (Table 2). During an initial 12-h dry period, populations fell by more than three orders of magnitude. A similar population decline occurred when plants initially exposed to wet conditions were subsequently exposed to dry conditions for $12 \mathrm{~h}$. Population level stabilized after an initial decline associated with the first dry period, despite later recurrence of dry periods. No differences were observed between AUC values when plants were exposed to an initial 12-h dry period after inoculation or when they were exposed to dry conditions throughout the entire experiment. 


\section{Discussion}

Our findings provide the first direct evidence that E. tracheiphila can survive for at least several days on muskmelon leaves. In the only previous study of epiphytic survival, Brust (9) demonstrated that placement of E. tracheiphila inoculum on muskmelon leaves followed by wounding up to 6 hours later could result in wilting.

Although E. tracheiphila is known primarily as a vascular pathogen, our findings suggest that it is also persistent and resilient as an epiphyte. High temperatures and exposure to dry periods clearly reduced survival of E. tracheiphila, whereas continuous wetness at optimum temperatures $\left(10\right.$ to $\left.20^{\circ} \mathrm{C}\right)$ clearly favored survival. These surviving populations could become important sources of inoculum, particularly if leaves become wounded by subsequent events such as high winds or insect feeding. Relatively low survival at 30 to $35^{\circ} \mathrm{C}$ is consistent with studies of other epiphytic phytopathogenic bacteria (3). Although dry conditions can impose severe stress on epiphytic bacteria (3, 29), E. tracheiphila populations stabilized at approximately $10^{3} \mathrm{CFU}$ per gram of fresh leaf tissue after two days of continuous dryness. Survival of E. tracheiphila under dry conditions may have resulted from selection for a subpopulation having a relatively high ability to endure water limitation (5) or occupy protected microsites on the leaf surface (31).

Our study also demonstrates that E. tracheiphila can persist on leaf surfaces in the absence of frass. Mitchell and Hanks (32) demonstrated an association between infested frass of striped cucumber beetle deposited on cucumber leaf surfaces and transmission of E. tracheiphila. Although Mitchell and Hanks did not determine how 
long the pathogen survived in frass, they showed that E. tracheiphila could survive in the beetle gut and in frass produced up to 24 hours after ingestion, and that punctureinoculation of infested frass on cucumber seedlings resulted in bacterial wilt infection.

Survival of E. tracheiphila in frass could play an important role the pathogen bacterial wilt disease cycle. It is reasonable to assume that survival of E. tracheiphila could be extended by its association with frass if substances (e.g., water, organic compounds) in the frass conferred protection against desiccation. It is also reasonable to assume that E. tracheiphila could be dispersed from frass by rain splash, and that this dissemination could increase the probability of contact with leaf wounds and thereby facilitate entry of inoculum into the plant. Sasu and co-workers (41) provided clear evidence that accumulation of infested beetle frass in floral nectaries may also lead to bacterial wilt infection. This discovery confirmed a second route for entry of the bacterial wilt pathogen in addition to entry through leaf wounds, reaffirming the importance of understanding the environmental biology of E. tracheiphila on plant surfaces.

Although our experiments were performed under controlled conditions, we showed that E. tracheiphila can persist on muskmelon leaves under conditions that resemble environmental fluctuations occurring in the field. For example, alternating 12hour wet and dry periods at $20^{\circ} \mathrm{C}$ roughly approximate conditions that occur in muskmelon production fields in the Midwest United States during the early part of the growing season (43), when plantings are at highest risk for infection by E. tracheiphila $(9,13,15,32,36)$. Taking into account the sporadic and poorly understood nature of 
bacterial wilt epidemics (40), a better understanding of the impact of environmental conditions on the risk of infection by epiphytic inoculum may improve management strategies and disease risk assessment.

To achieve a more realistic assessment of the role of epiphytic survival of $E$. tracheiphila in the bacterial wilt disease cycle, further investigation is needed: $i$ ) using more E. tracheiphila strains under a wider range of environmental conditions and longer periods; ii) documenting survival of epiphytic populations of E. tracheiphila under field conditions; iii) quantifying dispersal of E. tracheiphila on leaf surfaces by rain splash from frass; and iv) explicitly associating factors such as the size of E. tracheiphila epiphytic populations and environmental conditions that damage leaves with the risk of disease transmission. Our study has provided a foundation for taking the next steps in clarifying the role of epiphytic populations of E. tracheiphila in the epidemiology of this important pathosystem.

\section{Acknowledgements}

Special thanks to Alicia Owens, who helped develop many of the methods used in this study. We also thank Huanyu Li for technical assistance. We are grateful to Gwyn Beattie and Philip Dixon for their helpful comments on the manuscript. The project was funded by grants from the North Central Region IPM Center and U.S. Environmental Protection Agency Region VII Pesticide Environmental Stewardship Program (PESP). 


\section{Literature cited}

1. Alder, L. S. and R. V. Hazzard. 2009. A comparison of perimeter trap crop varieties: effects on herbivory, pollination and yield in butternut squash. Environ. Entomol. 38: 207-215.

2. Beattie, G. A. and S. E. Lindow. 1994. Survival, growth, and localization of epiphytic fitness mutants of Pseudomonas syringae on leaves. Appl. Environ. Microbiol. 60: 3790-3798.

3. Beattie, G. A. and S. E. Lindow. 1994. Comparison of the behavior of epiphytic fitness mutants of Pseudomonas syringae under controlled and field conditions. Appl. Environ. Microbiol. 60:3799-3808.

4. Beattie, G. A. and S. E. Lindow. 1995. The secret life of foliar bacterial pathogens on leaves. Annual Review of Phytopathology 33:145-172.

5. Beattie, G. A. and S. E. Lindow. 1999. Bacterial colonization of leaves: a spectrum of strategies. Phytopathology 98: 353-360.

6. Brewer, M.J., Story, R.N., Wright, V.L. 1987. Development of summer squash seedlings damaged by striped and spotted cucumber beetles (Colepotera: Chrysomelidae) Oecologia (Berl.) 50: 370-375.

7. Brust, G.E., Foster R.E. 1995. Semiochemical-based toxic baits for control of striped cucumber beetle (Coleoptera: Chrysomelidae) in cantaloupe. J. Econ Entomol. 88: 112-116. 
8. Brust, G.E., Foster, R.E., Buhler, W.G. Comparison of insecticide use programs for managing striped cucumber beetle (Colepotera: Chrysomelidae) in muskmelon. J. Econ. Entomol. 89:981-986.

9. Brust, G.E.1997. Interaction of Erwinia tracheiphila and muskmelon plants. Environ. Entomol. 26:849-853.

10. Burkholder, W.H.1960. Some observations on Erwinia tracheiphila, the causal agent of the cucurbit wilt. Phytopathology 50: 179-180.

11. Burkness, E.C., Hutchison W.D.1998. Development and validation of a fixedprecision sampling plan for estimating striped cucumber beetle (Coleoptera:Chrysomelidae) density in cucurbits. Pest management and sampling. 27:178-183.

12. Cavanagh, Hazzard R., Adler L. S., Boucher J.2009. Using Trap Crops for Control of Acalymma vittatum (Coleoptera: Chrysomelidae) Reduces Insecticide Use in Butternut Squash. J. Econ. Entomol. 102: 1101-1107.

13. deMackiewicz, D., Gildow, F.E., Blua, M., Fleischer, S.J., and Lukezic, F.L. 1998. Herbaceous weeds are not economically important reservoirs of Erwinia tracheiphila. Plant Dis. 82:521-529.

14. Fleischer S. J., M. D. Orzolek, D. deMackiewicz, L. Otjen. 1998. Imidacloprid effects on Acalymma vittata (Coleoptera: Chrysomelidae) and bacterial wilt in cantaloupe. J. Econ. Entomol. 940-949. 
15. Fleischer S.J., deMackiewicz, D., Gildow, F.E., and Lukezic, F.L. 1999.

Serological estimates of the seasonal dynamics of Erwinia tracheiphila in Acalymma vittata. Environ. Entomol. 28:470-476.

16. Garcia-Salazar, C.G., Gildow, F.E., Fleischer, S.J., Cox-Foster, D., and Lukezic, F.L. 2000. Alimentary canal of Acalymma vittatum (Coleoptera: Chrysomelidae):

Morphology and potential role in the survival of Erwinia tracheiphila

(Enterobacteriaceae). Can. Entomologist 132:1-13.

17. Hirano, S.S., Nordheim, E.V., Amy, D.C., Upper, C.D. 1982. Lognormal distribution of epiphytic bacterial populations on leaf surfaces. Appl. Environ. Microbiol. 44: 695-700.

18. Hodges, L., Baxendale, F. 2007. Bee pollination of cucurbit crops. University of Nebraska Lincoln Extension Bulletin G1754. 2 pp.

19. Hoffman, M. P.; Kirkwyland, J. J.; Smith, R. F. and Long, R. F.1996. Field tests with kairomone-baited traps for cucumber beetles and corn rootworms in cucurbits. Environ. Entomol. 25, 1172-1181.

20. Hoffman, M.P., Ayyappath, R., Kirkwyland, I.J.2000. Yield Response of Pumpkin and Winter Squash to Simulated Cucumber Beetle (Coleoptera: Chrysomelidae) Feeding Injury. J. Econ. Entomol.93:136-140.

21. Isaacs, R. and Tuell, J. 2007. Conserving Native Bees on Farmland. Michigan State University Extension Bulletin E-2985. 4 pp.

22. Jesse, L., M. Gleason, A. Owens, J. Batzer, D. Lewis, and H. Taber. 2007. Use of bumble bees to extend duration of row covers on muskmelon in Iowa. Abstract, 
Annual meeting of Entomological Society of America, San Diego, CA, December 2007.

23. Johnson, K.B., Sawyer, T.L., Temple, T.N. 2006. Rates of epiphytic growth of Erwinia amylovora on flowers common in landscape. Plant Dis. 90: 1331-1336.

24. Johnson, K.B., Stockwell, V.O.1998. Management of Fire Blight: a case study in microbial ecology. Annual Review of Phytopathology 36: 227-248.

25. Lam, W.F. 2007. An alternative sampling technique for cucumber beetles (Colepotera: Chrysomelidae) and diurnal beetle activity on muskmelon. J. Econ. Entomol. 100:823-829.

26. Latin, R.X. 1993. Diseases and pests of muskmelons and watermelons. Bulletin BP-44, Purdue University Extension.

27. Latin, R.X. APSnet Features. Bacterial Wilt. October 2000. http://www.apsnet.org/publications/apsnetfeatures/Pages/BacterialWilt.aspx

28. Leach, J. G. 1964. Observations on cucumber beetles as vectors of cucurbit wilt. Phytopathology 54: 606-607.

29. Leben, C. 1988. Relative humidity and the survival of epiphytic bacteria with buds and leaves of cucumber plants. Phytopathology 78:179-185.

30. Lewis, P. A., Lampman, R. L., Metcalf, R. L.1990. Kairomonal attractants for Acalymma vittatum (Coleoptera: Chrysomelidae). Environ. Entomol. 19: 8-14.

31. Lindow, S.E., Brandl, M.T.2003. Minireview: Microbiology of the phyllosphere. Appl. Environ. Microbiol. 69: 1875-1883. 
32. Mitchell, R.F., Hanks, L.M. 2009. Insect frass as a pathway for transmission of bacterial wilt of cucurbits. Environ. Entomol. 38: 395-403.

33. Mueller, D.S., Gleason, M.L., Sisson, A.J., and Massman, J.M. 2006. Effect of row covers on suppression of bacterial wilt of muskmelon in Iowa. Plant Health Progress. doi: 10.1094/PHP-2006-1020-02-RS.

34. NASS (National Agricultural Statistics Survey). 2010.USDA Vegetable 2009 Annual Summary. Vg1-2 (10). 87 pp.

35. Pair, S.D. 1997. Evaluation of systemically treated squash trap plants and attracticidal baits for early-season control of striped and spotted cucumber beetles (Coleoptera: Chrysomelidae) and squash bug (Hemiptera: Coreidae) in cucurbit crops. J. Econ. Entomol. 90: 1307-1314

36. Rand, F. V., Cash, L.1920. Some insect relations of Bacillus tracheiphilus Erw. Sm. Phytopathology 10: 133-140.

37. Rand, F. V., Enlows, E.M.A. 1916. Transmission and control of bacterial wilt of cucurbits. J. Agric. Res. 6: 417-434

38. Rouse, D.I., Nordheim, E.V., Hirano, S.S, Upper, C.D.1985. A model relating the probability of foliar disease incidence to the population frequencies of bacterial plant pathogens. Phytopathology.75: 505-509.

39. Saalau-Rojas, E. 2010. Bacterial wilt of cucurbits: Assessment of row covers in disease management, and of epiphytic survival and genetic diversity of the pathogen, Erwinia tracheiphila. MS Thesis. Iowa State University. Ames, IA. 
40. Saalau-Rojas, E., Batzer, J.C., Gleason, M.L. 2009. Efficacy of extended-duration row covers in suppressing bacterial wilt on muskmelon (Cucumis melo) in Iowa. Phytopathology (Abstr.) 100:S112.

41. Sasu, M. A., Seidl-Adams, I., Wall, K., Winsor, J. A., Stephenson, A. G.2010. Floral transmission of Erwinia tracheiphila by cucumber beetles in a Wild Cucurbita pepo. Envrion. Entomol. 39:140-148.

42. Schroth M. N., Thomson S. V., Hildebrand D. C., Moller W. J.1974.Epidemiology and control of Fire Blight. Annual Review of Phytopathology. 12:389-412.

43. Sentelhas, P.C., Dalla Marta A., Orlandini, S., Santos, E.A., Gillespie, T.J., Gleason, M.L. 2008. Suitability of relative humidity as an estimator of leaf wetness duration. Agricultural and Forest Meteorology 148:392-400.

44. Sherf, A.F., MacNab, A.A. 1986. Cucurbits, p. 307-311 in Vegetable diseases and their control. Wiley, New York.

45. Steiner, P.W. 1990. Predicting apple blossom infections by Erwinia amylovora using the MARYBLYT model. Acta Hort. 273:139-148.

46. Thomson, S.V., Schroth, M.N., Moller, W.J. 1982. A forecasting model for fire blight of pear. Plant Dis. 66: 576-57 
Table 1. Summary analysis of variance (ANOVA) on epiphytic populations of E. tracheiphila on muskmelon leaves under different temperature treatments and intermittent wet and dry periods. Mean Square Error (MSE) with residual error values were $24.4+1.47$ for survival at different temperatures and $0.66+0.28$ for survival under different wetness regimes.

\begin{tabular}{|c|c|c|c|c|}
\hline Source & $\mathbf{D F}^{\mathbf{a}}$ & Error $^{b}$ & F value & Pr $>$ F \\
\hline \multicolumn{5}{|c|}{ Survival at different temperatures } \\
\hline Run $^{c}$ & 1 & Run*temp $^{\mathrm{d}}$ & 8.56 & 0.0328 \\
\hline Temperature $^{\text {e }}$ & 5 & Run*temp & 19.93 & 0.0026 \\
\hline Sampling time ${ }^{\mathrm{f}}$ & 5 & Residual error & 253.47 & $<0.0001$ \\
\hline Temperature $*$ Sampling time & 25 & Residual error & 8.23 & $<0.0001$ \\
\hline \multicolumn{5}{|c|}{ Survival under intermittent wet/dry periods } \\
\hline Run $^{c}$ & 1 & Run*treatment $^{\mathrm{g}}$ & 18.00 & 0.0240 \\
\hline Treatment $^{\mathrm{h}}$ & 3 & Run*treatment & 83.89 & 0.0022 \\
\hline Sampling time ${ }^{\mathrm{f}}$ & 3 & Residual error & 497.47 & $<0.0001$ \\
\hline Treatment $*$ Sampling time & 9 & Residual error & 47.14 & $<0.0001$ \\
\hline \multicolumn{5}{|l|}{${ }^{\mathrm{a}}$ Degrees of freedom } \\
\hline \multicolumn{5}{|l|}{${ }^{\mathrm{b}}$ Error term used to test } \\
\hline \multicolumn{5}{|l|}{${ }^{\mathrm{c}}$ Run of each experiment } \\
\hline \multicolumn{5}{|c|}{${ }^{\mathrm{d}}$ Run of the experiment multiplied by temperature treatment } \\
\hline${ }^{\mathrm{e}}$ In dew chambers & & & & \\
\hline
\end{tabular}


${ }^{\mathrm{g}}$ Run of the experiment multiplied by wetness regime treatment

${ }^{\mathrm{h}}$ Wetness regime treatment 
Table 2. Comparison of area under the curve (AUC) values for epiphytic survival of $E$. tracheiphila on muskmelon leaves under different temperature treatments and intermittent wet and dry periods.

\begin{tabular}{lc}
\hline Treatment & AUC $^{\mathrm{s}}$ \\
\hline Temperature $^{\mathbf{t}}$ & \\
$10^{\circ} \mathrm{C}$ & $450.3 \mathrm{a}$ \\
$15^{\circ} \mathrm{C}$ & $446.0 \mathrm{a}$ \\
$20^{\circ} \mathrm{C}$ & $378.0 \mathrm{~b}$ \\
$25^{\circ} \mathrm{C}$ & $341.9 \mathrm{bc}$ \\
$30^{\circ} \mathrm{C}$ & $306.8 \mathrm{~cd}$ \\
$35^{\circ} \mathrm{C}$ & $259.5 \mathrm{~d}$ \\
LSD $^{\mathrm{u}}$ & 51.3 \\
Intermittent wet/dry periods $^{\mathbf{v}}$ \\
$12 \mathrm{~h}^{\text {wet } / 12 \text { h dry }^{\mathrm{w}}}$ \\
$12 \mathrm{dry} / 12 \mathrm{~h} \mathrm{wet}^{\mathrm{x}}$ & $229.4 \mathrm{~b}$ \\
$48 \mathrm{~h}$ wet & $184.6 \mathrm{c}$ \\
$48 \mathrm{~h} \mathrm{dry}^{\mathrm{z}}$ & $285.7 \mathrm{a}$ \\
LSD $^{\mathrm{u}}$ & $170.9 \mathrm{c}$ \\
\hline
\end{tabular}

${ }^{\mathrm{s}} \log _{10}$ of Area Under the Curve. Means in the same column followed by the same letter are not significantly different $(P=0.05)$.

${ }^{\mathrm{t}}$ Under wet conditions ( $\geq 95 \% \mathrm{RH}$ ) for $72 \mathrm{~h}$

${ }^{\mathrm{u}}$ Least Significant Difference $(P=0.05)$

${ }^{v}$ At $20^{\circ} \mathrm{C}$ for $48 \mathrm{~h}$

${ }^{\mathrm{w}}$ 12-h wet periods alternated with 12-h dry periods

x 12 -h dry periods alternated with 12-h wet periods

${ }^{\mathrm{y}}$ Continuous wetness 
${ }^{\mathrm{z}}$ Continuous dryness 
Figures
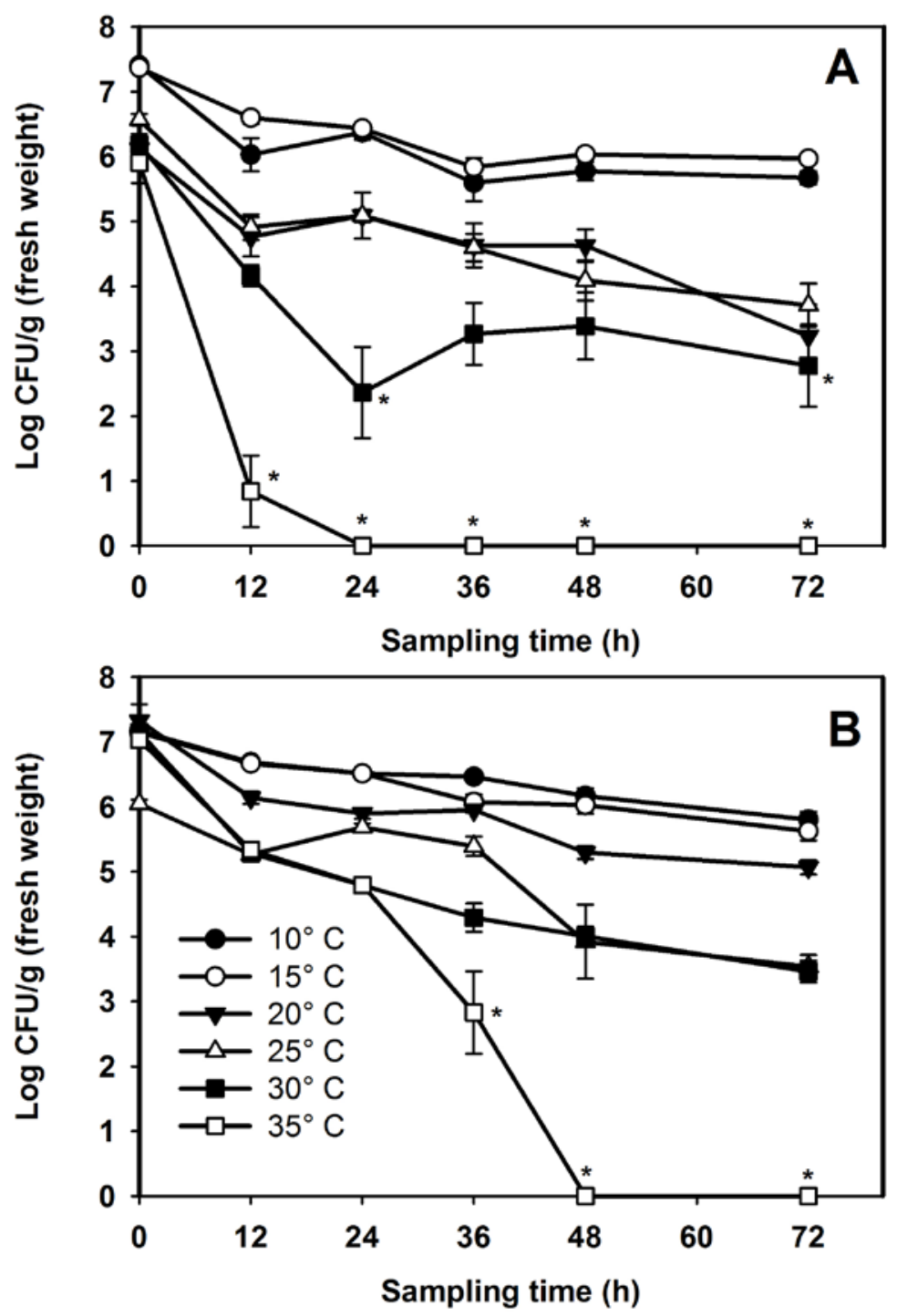

Figure 1. Epiphytic populations (expressed as $\log _{10}$ CFU per gram of fresh leaf weight) of Erwinia tracheiphila strain SCR3 on muskmelon leaves incubated for $72 \mathrm{~h}$ under wet conditions at six different temperatures. The experiment was performed twice; each data point in the first run (A) and second run (B) represents the mean \pm SE of 8 leaves. Data points below the detection limit (2.88 Log (CFU/g) are indicated by $\left(^{*}\right)$. 

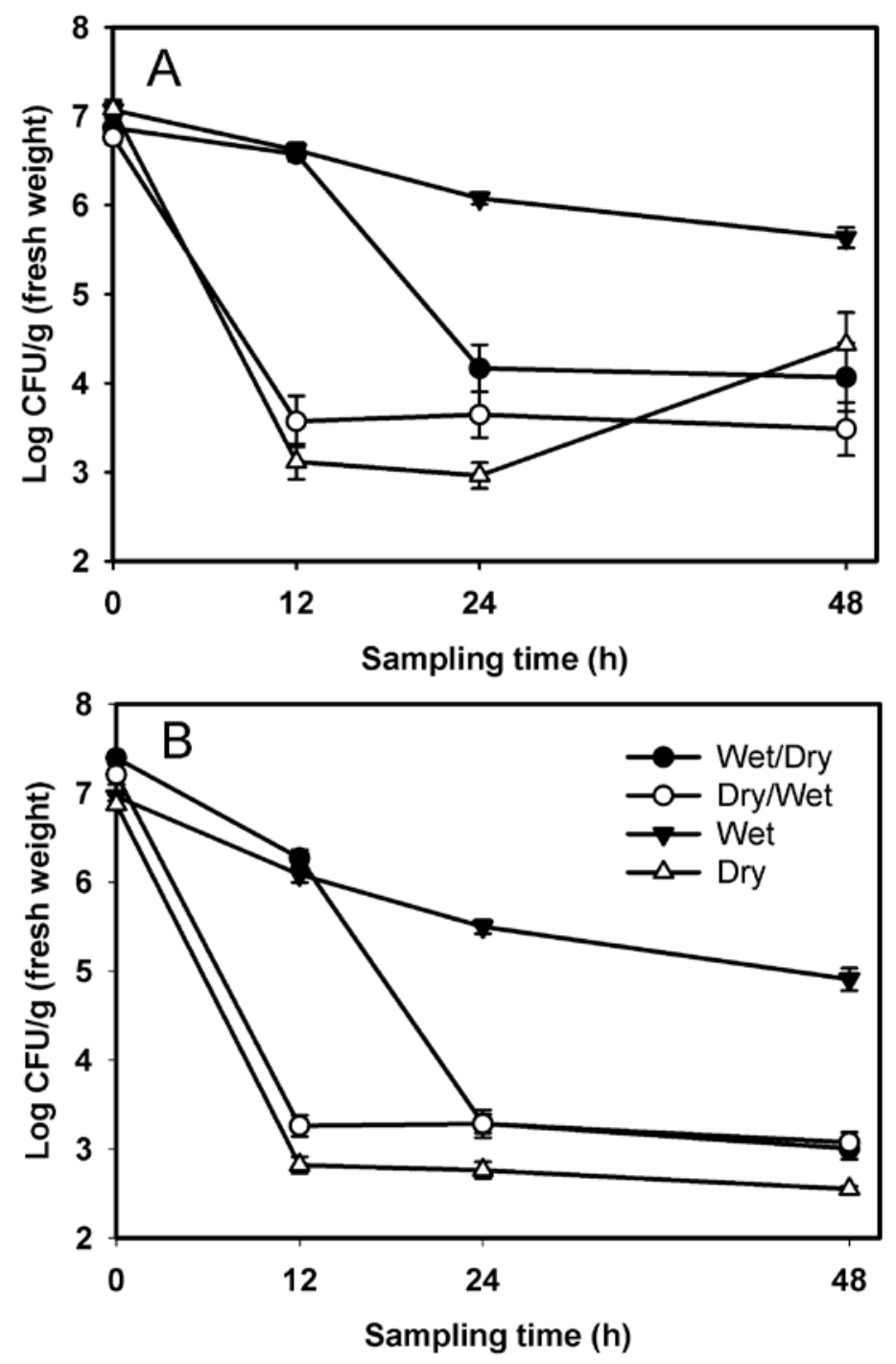

Figure 2. Epiphytic populations (expressed as $\log _{10} \mathrm{CFU}$ per gram of fresh leaf weight) of Erwinia tracheiphila strain SCR3 on muskmelon leaves incubated for $48 \mathrm{~h}$ at $20^{\circ} \mathrm{C}$ under alternating 12-h periods of wet and dry conditions. The experiment was performed twice; each data point in the first run (A) and second run (B) represents the mean \pm SE of 8 leaves. 


\title{
CHAPTER 4
}

\section{GENETIC AND VIRULENCE VARIABILITY AMONG ERWINIA TRACHEIPHILA STRAINS RECOVERED FROM DIFFERENT CUCURBIT HOSTS}

\author{
A manuscript accepted by Phytopathology \\ E. Saalau Rojas, P.M. Dixon, J.C. Batzer, M.L. Gleason
}

\begin{abstract}
The causal agent of cucurbit bacterial wilt, Erwinia tracheiphila, has a wide host range in Cucurbitaceae including economically important crops such as muskmelon (Cucumis melo L.), cucumber (Cucumis sativus L.), and squash (Cucurbita spp.). Genetic variability of 69 E. tracheiphila strains was investigated by rep-PCR using BOXA1R and ERIC1-2 primers. Fingerprint profiles revealed significant variability associated with crop host; strains isolated from Cucumis spp. were clearly distinguishable from Cucurbita-isolated strains regardless of geographic origin. Twelve E. tracheiphila strains isolated from muskmelon, cucumber, or summer squash were inoculated onto muskmelon and summer squash seedlings, followed by incubation in a growth chamber. Wilt symptoms were assessed over three weeks, strains were re-isolated, and rep-PCR profiles were compared to the inoculated strains. Wilting occurred significantly faster when seedlings were inoculated with strains that originated from the same crop host genus $(P<0.001)$. In the first run of the experiment, cucumber and muskmelon strains caused wilting on muskmelon seedlings at a median of 7.8 and 5.6 days after inoculation (dai), respectively. Summer squash seedlings wilted 18.0, 15.7, and 5.7 dai when
\end{abstract}


inoculated with muskmelon-, cucumber-, and squash-origin strains respectively. In a second run of the experiment, cucumber and muskmelon strains caused wilting on muskmelon at 7.0 and 6.9 dai, respectively, whereas summer squash seedlings wilted at 23.6, 29.0 and 9.0 dai when inoculated with muskmelon-, cucumber-, and squash-origin strains, respectively. Our results provide the first evidence of genetic diversity within $E$. tracheiphila and suggest that strain specificity is associated with plant host. This advance is a first step toward understanding the genetic and population structure of $E$. tracheiphila.

\section{Introduction}

Cucurbit bacterial wilt, caused by Erwinia tracheiphila (Smith), is among the most damaging diseases of cucurbit crops in the eastern half of the United States, where approximately $68 \%$ of the total U.S. cucurbit acreage is grown (23). Although the pathogen can cause significant damage to summer squash, pumpkin, and gourd, yield loss in muskmelon and cucumber, the most susceptible crops, can reach up to $80 \%$ (7, 14). Aside from its traditional importance in the eastern U.S., bacterial wilt may be expanding in geographic range, since it was recently reported from cucurbit crops in New Mexico (26).

Bacterial wilt management relies on insecticide seed treatments, in-furrow applications, and sprays, but their effectiveness can be erratic $(5,8)$. Pesticide -intensive strategies also pose severe health and environmental risks, particularly to pollinators and other beneficial insects $(13,33)$. Lack of knowledge of pathogen biology and pathogen- 
host interactions remains a substantial barrier to development of more effective and less hazardous management approaches.

Erwinia tracheiphila is transmitted by striped (Acalymma vittatum (Fabricious)) and spotted (Diabrotica undecimpunctata howardi Barber) cucumber beetles. In temperate regions, E. tracheiphila overwinters in the alimentary canal of adult $A$. vittatum $(9,10,25)$ and transmission occurs when bacteria-infested beetles deposit frass onto fresh feeding wounds $(1,15,25)$ or flower nectaries (27). Once inside the plant, bacteria multiply in the xylem vessels and produce exopolysaccharides that obstruct the vascular system, leading to wilting and total collapse of the plant in 7 to 21 days (27, 32).

Although E. tracheiphila can infect a wide range of cucurbit species, its genetic and pathogenic variability are unknown. In the few published studies that have classified E. tracheiphila strains using phenotypic methods, results have been variable (16). For example, de Mackiewicz et al. (7) reported that all isolates in the study had different carbon utilization profiles. Moreover, studies using molecular methods to group Erwinia species have seldom included more than one E. tracheiphila strain $(11,24,30)$ or identified the host cucurbit species from which the strain was obtained. The fact that E. tracheiphila strains are difficult to isolate and grow poorly on laboratory media (7, 11) may explain why the study of genetic structure in populations of E. tracheiphila has received little attention.

A molecular fingerprinting technique called rep-PCR has been used extensively to detect genetic variability and identify plant pathogenic bacteria $(18,28)$. Rep-PCR can 
distinguish closely related strains by amplifying highly conserved, non-coding repetitive elements interspersed throughout the bacterial genome. This technique helps identify subpopulations within bacterial species $(19,29)$.

Understanding the genetic diversity within Erwinia tracheiphila is essential to understanding the biology of the pathogen and epidemiology of cucurbit bacterial wilt. The objectives of this study were to $i$ ) investigate the genetic diversity of E. tracheiphila isolated from different cucurbit crop hosts and geographic locations in the United States, and ii) compare pathogenicity of E. tracheiphila strains on different cucurbit hosts to evaluate if these strains show any evidence of host specificity.

\section{Materials and Methods}

\section{Bacterial isolates and maintenance. Strains of Erwinia tracheiphila were} isolated in 2008 through 2010 from cucurbit plants showing bacterial wilt symptoms (Table 1). Plants from seven U.S. states were shipped overnight to Iowa State University. Symptomatic plant material was surface-sterilized by submerging 1-inchlong stem or petiole segments in $0.5 \% \mathrm{NaOCl}$ for 2 to $3 \mathrm{~min}$, followed by three rinses in sterile distilled water. Using sterile scalpel and forceps, the epidermis of each segment was removed and two transverse incisions were performed to excise small wedges of tissue, exposing xylem vessels. Radial sides of each wedge were dabbed onto nutrient agar peptone (NAP) and plates were incubated at $27^{\circ} \mathrm{C}$ for 3 to 5 days. Bacterial colonies resembling E. tracheiphila (4) were selected and streaked onto NAP plates. After 3 to 4 days, DNA from pure colonies was directly amplified using E. tracheiphila- 
specific primers ET1-2 and ETC1-2 (3, 21). Isolates confirmed as E. tracheiphila were maintained at $-80^{\circ} \mathrm{C}$ in Luria-Bertani broth (LB) with $25 \%$ glycerol.

DNA isolation and repetitive sequence-based PCR. Genomic DNA from $69 \mathrm{E}$. tracheiphila strains was extracted and purified using Wizard Genomic DNA purification kit (Promega; Madison, WI) following manufacturer's instructions. Genomic DNA was amplified using rep-PCR primer set ERIC (ERIC1R [5'-ATG TAA GCT CCT GGG GAT TCA C-3'] and ERIC2 [5'-AAG TAA GTG ACT GGG GTG AGC G-3’]) (28) and primer sequence corresponding to BOXA subunit (BOXA1R [5'-CTA CGG CAA GGC GAC GCT GAC G-3’]) (29). Each amplification reaction (25 $\mu \mathrm{l})$ had a final concentration of 1X Ex Taq Buffer (Mg ${ }^{2+}$ plus) (TaKara Bio Inc.; Shiga, Japan), 0.35mM dNTP, 1\% DMSO, 4 U Takara Ex Taq DNA polymerase (TaKara Bio Inc.), 1.0 $\mu \mathrm{M}$ of reverse and forward ERIC primers, $2.0 \mu \mathrm{M}$ BOXA1R primer, and $200 \mathrm{ng}$ of genomic DNA. PCR amplification was performed with a PTC-100 thermal cycler (MJ Research Inc.; Waltham, MA) using the following conditions: an initial denaturation at $94^{\circ} \mathrm{C}$ for 3 min followed by 35 cycles of denaturation at $94^{\circ} \mathrm{C}$ for $40 \mathrm{~s}$, annealing at $53^{\circ}$ C for ERIC1R-2 and at $52^{\circ} \mathrm{C}$ for BOXA1R for $45 \mathrm{~s}$, and extension at $68^{\circ} \mathrm{C}$ for $10 \mathrm{~min}$, with a final extension step at $68^{\circ} \mathrm{C}$ for $16 \mathrm{~min}$. Amplified PCR products were separated by gel electrophoresis on 1.6\% agarose gels in $0.5 \mathrm{X}$ Tris-Borate-EDTA (TBE) buffer at $5 \mathrm{~V} / \mathrm{cm}$. Agarose gels were stained with ethidium bromide and visualized under ultraviolet light. To determine DNA fingerprint reproducibility, samples were amplified twice and genomic DNA from independent single-colony isolates were run side by side 
on agarose gels. Fingerprint patterns were compared visually and confirmed using Quantity One 1-D analysis software (Bio-Rad Laboratories, Inc.; Hercules, CA).

Pathogenicity assays. Muskmelon (Cucumis melo L., cv. Athena) and summer squash (Cucurbita pepo L., cv. Early Summer Crookneck) seeds were planted in 233 $\mathrm{cm}^{3}$ pots (Nu-Pot 3; Summit Plastic Co., Akron, $\mathrm{OH}$ ) containing 40\% peat moss, 40\% prepared substrate (Sunshine Mix SB300; Sun Gro Horticulture, Canada Ltd.;

Vancouver, BC, Canada), and 20\% coarse perlite. Muskmelon and summer squash plants were maintained in growth chambers for 7 to 13 days respectively, at $26^{\circ} \mathrm{C}$ under $14 \mathrm{~h} \mathrm{day}^{-1}$ light and $10 \mathrm{~h} \mathrm{day}^{-1}$ darkness, until unfolding of the first true leaf.

Bacterial isolates from different cucurbit crop hosts were recovered from longterm storage at $-80^{\circ} \mathrm{C}$ (Table 1 ), streaked onto NAP plates and incubated at $27^{\circ} \mathrm{C}$ for 3 days. On the day of inoculation, bacterial colonies were diluted in $5 \mathrm{ml}$ of sterile $10 \mathrm{mM}$ phosphate-buffered saline (PBS) solution (pH 7.4) using a sterile cotton swab, and suspensions were adjusted to approximately $2.5 \times 10^{8} \mathrm{CFU} / \mathrm{ml}$. Immediately before inoculation, bacterial suspensions were shaken vigorously and a $100-\mu l$ aliquot was placed on the upper surface of the first true leaf. Using a 28.6-mm-diameter florist's pin frog, leaves were puncture-inoculated through the inoculum droplet and an additional 100- $\mu$ l aliquot of bacterial suspension was immediately spread over the punctured area. The same procedure was performed using sterile $10 \mathrm{mM}$ phosphate-buffered saline (PBS) solution (pH 7.4) for control plants. Inoculated plants and mock-inoculated controls were immediately placed in growth chambers and maintained at $26^{\circ} \mathrm{C}$ under $14 \mathrm{~h} \mathrm{day}^{-1}$ light and 10 h day $^{-1}$ darkness. Each strain was inoculated onto four seedlings, and an 
additional four seedlings were also included as controls. The incidence of seedlings showing wilt symptoms was recorded daily for three weeks. Three weeks after inoculation, bacterial isolations were attempted from stems and petioles of inoculated and control plants as described above. Genomic DNA of colonies resembling $E$. tracheiphila was purified and amplified using rep-PCR as previously described. RepPCR banding patterns from isolated strains were visually compared to rep-PCR fingerprints from strains that had been inoculated onto seedlings three weeks earlier. The experimental design was a split plot, where host was assigned as the whole-plot effect and isolate as the sub-plot effect. The experiment was performed twice.

Data analysis. Pathogenicity assay data sets included censored observations (seedlings that had not wilted by the end of experiment); therefore, parametric survival analysis was applied to quantify the effect of different E. tracheiphila strains on time to wilting. Because observations were made every 2 days, date of wilting was treated as an interval-censored value. For example, a seedling on which symptoms were first observed on day eight was entered as symptomatic during the interval between days six and eight. Some groups had no observed wilt, which led to an estimated time to wilt of infinity. These groups were resolved by defining asymptomatic plants as wilted during the interval between day 25 and 26 days after inoculation (dai). Each run of the experiment was analyzed separately because the magnitude of difference between hosts differed slightly between experiments and because of a significant interaction with experiment. The vector of parameter estimates and their variance-covariance matrix were generated using the PROC LIFEREG procedure in SAS (SAS Institute Inc., Version 9.1; Cary, 
NC) using the Lognormal model to describe the underlying unobserved wilt time distribution. Lsmeans, contrasts, and their standard errors were estimated using $\mathrm{R}$ statistical software (R Foundation for Statistical Computing, Version 2.15.0; Vienna, Austria) and median days to wilt were estimated by back-transforming the lsmeans.

\section{Results}

Genomic fingerprinting of strains. Among 69 strains isolated from five different cucurbit species sampled in eight U.S. states, two distinct fingerprint patterns were identified using rep-PCR (Fig. 1). These patterns were consistent within host species (Table 1) but distinct between host genera (Cucumis and Cucurbita). Amplification using ERIC1-2 and BOXA1R primers yielded nine to 15 distinct PCR bands, ranging from 200 to 12,000 bp in size (Fig. 1). Band size considered for strain comparison ranged between 400 and 6,000 bp. Fingerprint profiles generated with BOXA1R distinguished strains isolated from Cucumis hosts (lanes 1-3 and 10-11) and Cucurbita hosts (lanes 4-9). Bands generated from Cucumis-isolated strains were distinguishable by eye, particularly bands ranging from 2,500 bp to approximately 3,500 bp. Three to four bands were consistently noted within this range, whereas only two bands were observed among Cucurbita-isolated strains in the same size range. Strains isolated from Cucurbita sp. host plants showed distinct polymorphisms at approximately 500 to $670,1,120$, and 1,870 bp. Distinct patterns were also observed using the ERIC1-2 primer set (Fig. 1B). Cucumis-isolated strains from muskmelon and cucumber plants yielded similar band profiles, characterized by the presence of 12 to 15 distinct bands 
(lanes 1-3, 10-11).Cucumis strains showed distinct bands from those generated by Cucurbita strains between 2,000 and 1,650 bp. However, one of the bands, approximately 1, $870 \mathrm{bp}$, was not consistently amplified among samples and therefore was not considered for analysis. Similarly, a second band, approximately $1,520 \mathrm{bp}$, was present in some but not all the profiles generated by Cucumis strains. There was no apparent association of presence or absence of this band with host origin; therefore, it was not considered for analysis. In contrast, all Cucurbita-isolated strains consistently yielded eight to nine distinct bands (lanes 4-9). Patterns were easily distinguishable by eye, particularly bands between 650 and 3,000 bp.

\section{Pathogenicity and virulence of $E$. tracheiphila isolates on cucurbit hosts.}

Variation in pathogenicity (ability to cause disease) and virulence (time in days to wilt) was observed among 12 E. tracheiphila isolates obtained from muskmelon, cucumber, and summer squash hosts (Fig. 2). In the first run of the experiment all inoculated muskmelon plants wilted, despite strain origin, within 21 days after inoculation (dai). In contrast, the proportion of infected summer squash plants varied depending on whether muskmelon- or cucumber-origin strains were used to inoculate seedlings, whereas all summer squash seedlings wilted when inoculated with squash-origin strains. When the experiment was repeated, most muskmelon or cucumber-origin strains caused wilting on muskmelon by the end of the experiment, whereas only one of the summer squash strains induced wilt on all inoculated muskmelon seedlings. Conversely, summer squash seedlings showed few or no wilt symptoms when inoculated with muskmelon- or cucumber-origin strains, whereas all summer squash seedlings wilted when inoculated 
with strains that originated from summer squash. No wilt symptoms were observed in any of the mock-inoculated controls.

Results from survival analysis indicated that, when E.tracheiphila isolates originated from the same crop genus as the inoculated plants, seedlings wilted significantly faster than when strains originated from a different host genus (Fig. 2). In the first run of the experiment, for example, when isolates obtained from naturally infected muskmelon plants were inoculated onto muskmelon, seedlings wilted significantly faster (5.6 dai) than muskmelon seedlings that had been inoculated with isolates obtained from naturally infected squash plants (16.8 dai) $(P<0.0001)$. Conversely, when muskmelon and cucumber-origin strains were inoculated onto summer squash seedlings, wilt occurred at a median of 18.0 and 15.7 dai, respectively $(P=0.03)$, whereas squash-origin strains caused wilting on squash at a median of 5.7 dai. Similar results were obtained in the second run of the experiment; more days to wilting were required for muskmelon than summer squash seedlings when squash-origin strains were used for inoculations $(P=0.0001)$. In the second run of the experiment, no differences on median days to wilt were detected when cucumber and muskmelon strains were inoculated onto muskmelon seedlings $(P=1.0)$ at 7.0 and 6.9 dai, respectively. In contrast, summer squash seedlings wilted at a median of 23.6, 29.0, and 9.0 dai when inoculated with muskmelon-, cucumber-, and squash-origin strains, respectively. In the first run of the experiment, strains were successfully re-isolated from all inoculated seedlings, and BOXA1R and ERIC1-2 fingerprint profiles were consistent with those of the inoculated strains. In the second run, 20 of the 24 originally inoculated 
strains were isolated from the wilted plants and fingerprint patterns were again consistent with patterns of the inoculated strains. The other four strains were not reisolated due to the deteriorated state of the seedlings by the end of the experiment and contaminants on the plates. No E. tracheiphila strains were recovered from mockinoculated plants.

\section{Discussion}

This study is the first to demonstrate genetic variability among Erwinia tracheiphila strains, and to show a possible relationship between genetic variability and host-specific virulence. By using rep-PCR fingerprint analysis, we were able to clearly distinguish E. tracheiphila strains into two groups based on host genus, regardless of geographic origin. Strains isolated from Cucumis sp. hosts (muskmelon and cucumber) produced similar rep-PCR profiles using BOXA1R and ERIC1-2 primer sets, and these differed substantially from profiles generated by Cucurbita sp. hosts. Although neither the biological significance nor the loci associated with these differences has been determined, results from pathogenicity assays revealed that E. tracheiphila strains exhibited greater virulence on their host genus of origin.

Rep-PCR fingerprints correspond to repetitive non-coding sequences interspersed throughout the bacterial genome (29). Based on the consistency of fingerprint profiles detected in our study, rep-PCR patterns could reflect a well-defined strain adaptation in which plant host could be a major driving factor for pathogen selection. Although fingerprint profiles were easily distinguishable between Cucumis and Cucurbita-derived 
strains, profiles generated within Cucumis strains yielded some inconsistent polymorphisms when using ERIC1-2 primer set. These differences should be explored further, perhaps by including a third set of primers such as REP1-2. Additional analysis could potentially provide a clear distinction between strains isolated from Cucumis hosts and yield a specific fingerprint profile to host species level. Overall, our findings suggest that E. tracheiphila strains have co-evolved with their plant hosts within Cucurbitaceae. Further research could elucidate the impact of geographical distribution of different cucurbit crops on distribution of the pathogen in North America.

All E. tracheiphila strains were highly virulent when inoculated onto plant hosts in the same genus from which they were originally isolated. However, virulence varied significantly when E. tracheiphila strains were inoculated onto a crop host in the other genus. Although virulence variation among E. tracheiphila strains has been noted in previous studies, these differences were unexplained or attributed to loss of virulence during storage $(21,25)$. Based on our data, variable results in prior studies could potentially be explained by adaptation of E. tracheiphila to different genera of cucurbit hosts. This finding has important implications when matching E. tracheiphila strains with cucurbit plant hosts for resistance breeding.

Erwinia tracheiphila has a wide host range within Cucurbitaceae; cucumber, muskmelon, and squash are considered highly susceptible crops $(1,7,8)$. Recently, bacterial wilt was reported in watermelon (Citrullus lanatus), which was previously not considered to be a host of E. tracheiphila (26). It is reasonable to assume that this report could be evidence of host range expansion, perhaps due to the adaptation of $E$. 
tracheiphila strains to this genus. Host range determinants such as toxins, enzymes, and avirulence genes (12) could play a significant role in pathogen adaptation, but these determinants remain unstudied in the cucurbit bacterial wilt pathosystem. Our fingerprint and pathogenicity assay data support the hypothesis that the cucurbit bacterial wilt complex consists of distinct groups of E. tracheiphila strains. Comparison of colonization and infection processes among these groups could help to pinpoint virulence factors involved in delimiting the plant host range of cucurbit bacterial wilt. The genetic diversity and differential virulence findings among Erwinia tracheiphila isolates suggest that differences arise from selection that occurs within the plant host. However, because E. tracheiphila is insect-transmitted, pathogen-vector and host-vector interactions should also be investigated as potential selection factors. The genetic basis of the interaction between cucumber beetles and E. tracheiphila is currently unknown $(10,21,22)$. In a similar pathosystem, Stewart's wilt of maize, colonization of corn flea beetles by the bacterium Pantoea stewartii is associated with distinct genetic markers (22). Furthermore, a specific type III secretion system in the $P$. stewartii genome, typical of animal-infecting bacteria, has been associated with colonization and retention by its insect vector (6). Since E. tracheiphila is also highly dependent on insect vectors for overwintering and transmission, it is reasonable to propose that a similar system could exist in E. tracheiphila strains. Analogous approaches to studying the interaction between E. tracheiphila and cucumber beetles could provide more insight into the population and genetic structure of E. tracheiphila 
and help to explain how pathogen-host-vector interactions affect cucurbit bacterial wilt epidemiology and geographical distribution.

Assessment of population structure and diversity can have immediate

applicability in the development of disease control strategies (20). Although differential susceptibility to bacterial wilt has been documented in several important cucurbit crops (2, 31), no bacterial wilt-resistant cucurbit cultivars are commercially available. Elucidating genetic diversity and virulence variability among E. tracheiphila strains could set the stage for detection of genetic markers of host resistance. Furthermore, description of bacterial virulence factors has contributed in the elucidation of plant defense mechanisms and pathogen-host interactions (17). Our research is a first step in clarifying the genetic and population structure of E. tracheiphila, but additional research in this area is critical for the development of more effective and less hazardous control strategies against cucurbit bacterial wilt.

\section{Acknowledgements}

This research was funded by grants from the North Central Region IPM Center and U.S. Environmental Protection Agency Region VII Pesticide Environmental Stewardship Program (PESP). We thank Larry Halverson and Gwyn Beattie for their guidance in developing several methods used in this project, and Gwyn Beattie for valuable suggestions during manuscript preparation; Karl Pazdernik for help with statistical analyses; and Jennifer Foster, Lori Shapiro, Tom Creswell, Mark Williams, 
Meg McGrath, Tom Zitter, Rob Wick, Simeon Wright, Sally Miller, Dan Egel, Karen

Rane, Ric Bessin, and Benny Bruton for supplying symptomatic plant material.

\section{Literature cited}

1. Brust, G. E. 1997. Interaction of Erwinia tracheiphila and muskmelon plants. Environ. Entomol. 26:849-854.

2. Brust, G. E. and Rane, K. K. 1995. Differential occurrence of bacterial wilt in muskmelon due to preferential striped cucumber beetle feeding. HortScience 30: 1043-1045.

3. Bruton, B.D., Melcher, U., Zitter, T., Pair, S.D., Fletcher, J., and Mitchell, F. 1999. Polymerase chain reaction for detection of Erwinia tracheiphila in cucurbits. Phytopathology 89:S10.

4. Burkholder, W.H.1960.Some observations on Erwinia tracheiphila, the causal agent of the cucurbit wilt. Phytopathology 50: 179-180.

5. Cavanagh, A., Hazzard, R., Adler, L. S., and Boucher, J. 2009. Using Trap Crops for Control of Acalymma vittatum (Coleoptera: Chrysomelidae) Reduces Insecticide Use in Butternut Squash. J. Econ. Entomol. 102: 1101-1107.

6. Correa, V.R., Majerczak, D.R., Ammar, el-D, Merighi M., Pratt, R.C., Hogenhout, S.A., Coplin, D.L., and Redinbaugh, M.G. 2012. The bacterium Pantoea stewartii uses two different type III secretion systems to colonize its plant host and insect vector. Appl. Environ. Microbiol.78:6327-36. 
7. deMackiewicz, D., Gildow, F.E., Blua, M., Fliescher, S.J., and Lukezic, F.L. 1998. Herbaceous weeds are not economically important reservoirs of Erwinia tracheiphila. Plant Dis. 82:521-529.

8. Fleischer, S. J., Orzolek, M. D., deMackiewicz, D., and Otjen, L. 1998. Imidacloprid effects on Acalymma vittata (Coleoptera: Chrysomelidae) and bacterial wilt in cantaloupe. J. Econ. Entomol. 91: 940-949.

9. Fleischer, S.J., deMackiewicz, D., Gildow, F.E., and Lukezic, F.L. 1999. Serological estimates of the seasonal dynamics of Erwinia tracheiphila in Acalymma vittata. Environ. Entomol. 28:470-476.

10. Garcia-Salazar, C.G., Gildow, F.E., Fleischer, S.J., Cox-Foster, D., and Lukezic, F.L. 2000. Alimentary canal of Acalymma vittatum (Coleoptera: Chrysomelidae): Morphology and potential role in the survival of Erwinia tracheiphila (Enterobacteriaceae). Can. Entomologist 132:1-13.

11. Hauben, L., Moore, E. R. B., Vauterin, L., Steenackers, M., Verdonck, L., and Swings, J. 1998. Phylogenetic position of phytopathogens within the Enterobacteriacae. Syst. Appl. Microbiol. 21: 384-397.

12. Keen, N. T. and B. Staskawicz. 1988. Host range determinants in plant pathogens and symbionts. Annu. Rev. Microbiol.42:421-440.

13. Kremen, C., Williams, N.M., and Thorp, R.W. 2002. Crop pollination from native bees at risk from agricultural intensification. PNAS 99: 16812-16816.

14. Latin, R.X. 1993. Diseases and pests of muskmelons and watermelons. Bulletin BP-44, Purdue University Extension. 
15. Leach, J. G. 1964. Observations on cucumber beetles as vectors of cucurbit wilt. Phytopathology 54: 606-607.

16. Lelliott, R. A. and Dickey, R. S.1984. Genus VII. Erwinia Winslow, Broadhurst, Buchanan, Krumwiede, Rogers and Smith 1920. In Bergey’s Manual of Systematic Bacteriology, pp. 469-476. Edited by N. R. Krieg \& J. G. Holt. Baltimore:Williams \& Wilkins.

17. Lindeberg, M. 2012. Genome-enabled perspectives on the composition, evolution, and expression of virulence determinants in bacterial plant pathogens. Annu. Rev. Phytopathol. 50:111-32.

18. Louws, F. J., Bell, J., Medina-Mora, C. M., Smart, C. D., Opgenorth, D., Ishimaru, C. A., Hausbeck, M. K., Bruijn, F. J. de, and Fulbright, D. W. 1998. Rep-PCR-mediated genomic fingerprinting: a rapid and effective method to identify Clavibacter michiganensis. Phytopathology 88: 862-868.

19. Louws, F. J., Fulbright, D. W., Stephens, C. T., and Bruijn, F. J. de . 1994. Specific genome fingerprints of phytopathogenic Xanthomonas and Pseudomonas pathovars and strains generated with repetitive sequences and PCR. App. Environ. Microbiol. 60: 2286-2295.

20. Louws, F.J., Rademaker, J., and de Bruijn, F.1999. The three D’s of PCR-based genomic analysis of phytobacteria: Diversity, Detection, and Disease Diagnosis. Annu. Rev. Phytopathol. 37:81-125.

21. Mitchell, R.F. and Hanks, L.M. 2009. Insect frass as a pathway for transmission of bacterial wilt of cucurbits. Environ. Entomol. 38: 395-403. 
22. Nadarasah, G. and Stavrinides, J. 2011. Insects as alternative hosts for phytopathogenic bacteria. FEMS Microbiol. Rev. 35: 555-575.

23. NASS (National Agricultural Statistics Survey).2010.USDA Vegetable 2009 Annual Summary. Vg1-2 (10). 87 pp.

24. Naum, M., Brown, E.W., and Mason-Gamer, R.J.2008. Is 16S rDNA a reliable phylogenetic marker to characterize relationships below the family level in the Enterobacteriaceae? J. Mol. Evol. 66: 630-642.

25. Rand, F. V. and Enlows, E.M.A. 1916. Transmission and control of bacterial wilt of cucurbits. J. Agric. Res. 6: 417-434.

26. Sanogo, S., Etarock, B. F., and Clary, M. 2011. First report of bacterial wilt caused by Erwinia tracheiphila on pumpkin and watermelon in New Mexico. Plant Dis. 95: 1583.

27. Sasu, M. A., Seidl-Adams, I., Wall, K., Winsor, J. A., and Stephenson, A. G. 2010. Floral transmission of Erwinia tracheiphila by cucumber beetles in a wild Cucurbita pepo. Environ. Entomol. 39: 140-148.

28. Versalovic, J., Koeuth, T., and Lupski, J.R. 1991. Distribution of repetitive DNA sequences in eubacteria and application to fingerprinting of bacterial genomes. Nucl. Acids Res. 19: 6823-6831.

29. Versalovic, J., Schneider, M., de Bruijn, F.J., and Lupski, J.R. 1994. Genomic fingerprinting of bacteria using repetitive sequence based PCR (rep-PCR). Meth.Cell. Mol. Biol. 5: 25-40 
30. Waleron, M., Waleron, K., Podhajska, A., and Lojkowka, E. 2002. Genotyping of bacteria belonging to the former Erwinia genus by PCR-RFLP analysis of a recA gene fragment. Microbiology 148: 583-595.

31. Watterson, J. C., Williams, P. H., and Durbin, R. D. 1972. Multiplication and movement of Erwinia tracheiphila in resistant and susceptible cucurbits. Plant Dis. Rep. 56: 949-953.

32. Yao, C., Zehnder, G., Bauske, E., and Kloepper, J. 1996. Relationship between cucumber beetle (Coleoptera: Chrysomelidae) density and incidence of bacterial wilt of cucurbits. J. Econ. Entomol. 89: 510-514.

33. Zalom, F. G., Toscano, N. C., and Byrne, F. J. 2005. Managing resistance is critical to future use of pyrethroids and neonicotinoids. Calif. Agri. 59: 11-15. 


\section{Table}

Table 1. E. tracheiphila isolates, their crop host and geographic origin, year of isolation, and designated rep-PCR pattern profile.

\begin{tabular}{|c|c|c|c|c|}
\hline Isolate & Host & Location & $\begin{array}{c}\text { Year } \\
\text { isolated }\end{array}$ & $\begin{array}{c}\text { Rep-PCR } \\
\text { pattern }^{b}\end{array}$ \\
\hline BoCa4-1b & Cucumis melo L. & Iowa & 2008 & $\mathrm{~A}$ \\
\hline BoCa5-1 & Cucumis melo L. & Iowa & 2008 & A \\
\hline FCa2-3 & Cucumis melo L. & Iowa & 2008 & A \\
\hline GHM3-1 & Cucumis melo L. & Iowa & 2008 & A \\
\hline HM2-2 & Cucumis melo L. & Iowa & 2008 & A \\
\hline M2Ca2 & Cucumis melo L. & Iowa & 2008 & A \\
\hline MCa1-1 & Cucumis melo L. & Iowa & 2008 & A \\
\hline MCa4-2 & Cucumis melo L. & Iowa & 2008 & A \\
\hline KYMusk $^{\mathrm{a}}$ & Cucumis melo L. & Kentucky & 2009 & A \\
\hline McM1-1 & Cucumis melo L. & Iowa & 2009 & A \\
\hline McM2-4 & Cucumis melo L. & Iowa & 2009 & A \\
\hline UnisCa1-5 & Cucumis melo L. & Iowa & 2009 & A \\
\hline MBrut1 & Cucumis melo L. & Oklahoma & 2009 & A \\
\hline MBrut3 & Cucumis melo L. & Oklahoma & 2009 & A \\
\hline MBrut4 & Cucumis melo L. & Oklahoma & 2009 & A \\
\hline MBrut6 & Cucumis melo L. & Oklahoma & 2009 & A \\
\hline MBrut7 & Cucumis melo L. & Oklahoma & 2009 & A \\
\hline
\end{tabular}




\begin{tabular}{lllll}
\hline Musk1IN & Cucumis melo L. & Indiana & 2010 & A \\
Musk2IN & Cucumis melo L. & Indiana & 2010 & A \\
HFMusk $^{\text {a }}$ & Cucumis melo L. & Iowa & 2010 & A \\
LamMusk1 & Cucumis melo L. & Iowa & 2010 & A \\
LamMusk2 & Cucumis melo L. & Iowa & 2010 & A \\
MaMax & Cucumis melo L. & Maryland & 2010 & A \\
LIMusk1 & Cucumis melo L. & New York & 2010 & A \\
LIMusk2 & Cucumis melo L. & New York & 2010 & A \\
LIMusk3 & Cucumis melo L. & New York & 2010 & A \\
ZimmMusk & Cucumis melo L. & Iowa & 2010 & A \\
OKDH1 & Cucumis melo L. & Oklahoma & 2010 & A \\
OKMusk1 & Cucumis melo L. & Oklahoma & 2010 & A \\
OKMusk2 & Cucumis melo L. & Oklahoma & 2010 & A \\
OKMusk3 & Cucumis melo L. & Oklahoma & 2010 & A \\
BoCu1-2 & Cucumis sativus L. & Iowa & 2008 & A \\
BoCu2-1 & Cucumis sativus L. & Iowa & 2008 & A \\
BoCu3-1b & Cucumis sativus L. & Iowa & 2008 & A \\
FCu1-3 & Cucumis sativus L. & Iowa & 2008 & A \\
FCu3-3 & Cucumis sativus L. & Iowa & 2008 & A \\
HCu & Cucumis sativus L. & Iowa & 2008 & A \\
HCu1-4 & Cucumis sativus L. & Iowa & 2008 & A \\
Fish3-2 & Cucumis sativus L. & Iowa & 2009 & A \\
\hline
\end{tabular}




\begin{tabular}{|c|c|c|c|c|}
\hline FishCu1-5 & Cucumis sativus L. & Iowa & 2009 & A \\
\hline FishCu3-1 & Cucumis sativus L. & Iowa & 2009 & A \\
\hline TPINCu1 & Cucumis sativus L. & Indiana & 2009 & A \\
\hline TPINCu2 & Cucumis sativus L. & Indiana & 2009 & A \\
\hline TedCu & Cucumis sativus L. & Iowa & 2009 & A \\
\hline UnisCu1-1 & Cucumis sativus L. & Iowa & 2009 & A \\
\hline BontCu & Cucumis sativus L. & Iowa & 2010 & A \\
\hline Cuke1IN ${ }^{\mathrm{a}}$ & Cucumis sativus L. & Indiana & 2010 & A \\
\hline GrinCu & Cucumis sativus L. & Iowa & 2010 & A \\
\hline GuthCu & Cucumis sativus L. & Iowa & 2010 & A \\
\hline MDCuke $^{a}$ & Cucumis sativus L. & Maryland & 2010 & A \\
\hline $\operatorname{TedCu}(10)^{\mathrm{a}}$ & Cucumis sativus L. & Iowa & 2010 & A \\
\hline LICuke1 & Cucumis sativus L. & New York & 2010 & A \\
\hline LICuke2 & Cucumis sativus L. & New York & 2010 & A \\
\hline ZittCuke1 $^{\mathrm{a}}$ & Cucumis sativus L. & New York & 2010 & A \\
\hline ZittCuke2 & Cucumis sativus L. & New York & 2010 & A \\
\hline $\mathrm{HFCu}$ & Cucumis sativus L. & Iowa & 2010 & A \\
\hline BHKY & Cucurbita moschata & Kentucky & 2010 & B \\
\hline MIAcSq & Cucurbita pepo L. & Michigan & 2009 & $\mathrm{~B}$ \\
\hline $\mathrm{MISpSq}^{\mathrm{a}}$ & Cucurbita pepo L. & Michigan & 2009 & B \\
\hline GZ4 & Cucurbita pepo L. & New York & 2009 & B \\
\hline NYAcSq1 ${ }^{\text {a }}$ & Cucurbita pepo L. & New York & 2009 & B \\
\hline
\end{tabular}




\begin{tabular}{lllll}
\hline NYAcSq2 & Cucurbita pepo L. & New York & 2009 & B \\
NYZuch1 & Cucurbita pepo L. & New York & 2009 & B \\
NYZuch2 & Cucurbita pepo L. & New York & 2009 & B \\
PPHow1 & Cucurbita pepo L. & Pennsylvania & 2009 & B \\
PPHow2 & Cucurbita pepo L. & Pennsylvania & 2009 & B \\
LISumSq1 & Cucurbita pepo L. & New York & 2010 & B \\
LISumSq3 & Cucurbita pepo L. & New York & 2010 & B \\
& Cucurbita pepo ssp. & & & \\
BuffGH & texana & Pennsylvania & 2009 & B \\
\hline
\end{tabular}

${ }^{a}$ Strains used in pathogenicity assays

${ }^{\mathrm{b}}$ Fingerprint profiles were generated using primer sets BOXA1R and ERIC1-2. 


\section{Figures}
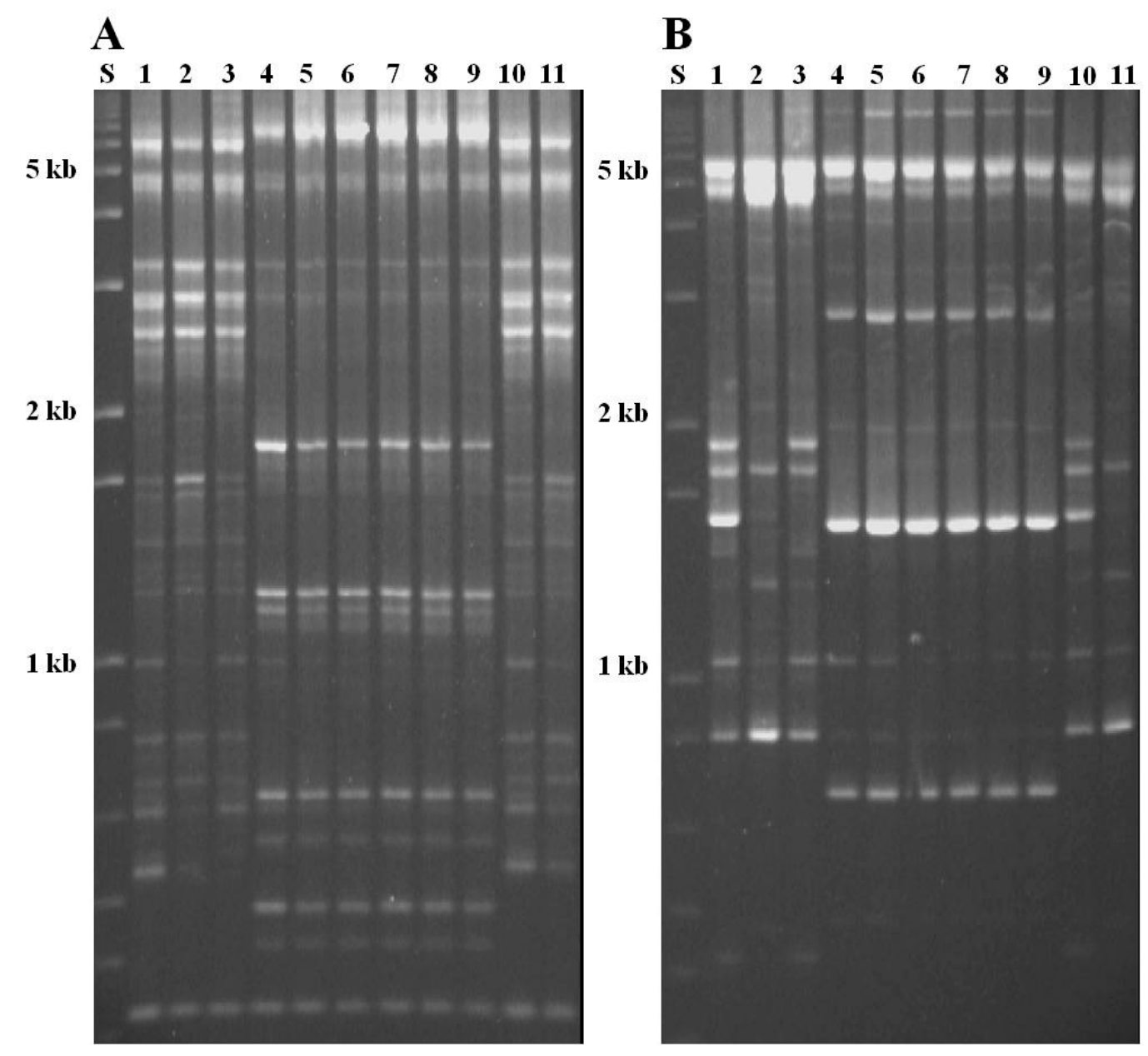

Figure 1. Fingerprint profiles generated using rep-PCR primer sets BOXA1R (A) and ERIC1-2 (B) using genomic DNA of E. tracheiphila strains. Amplification products were separated in 1.6\% agarose gels and stained with ethidium bormide for visualization under UV light. Lanes correspond to molecular size marker (S), Cucumis-origin strains (lanes, 1-3, and 10-11), and Cucurbita-origin strains (lanes 4-9). 

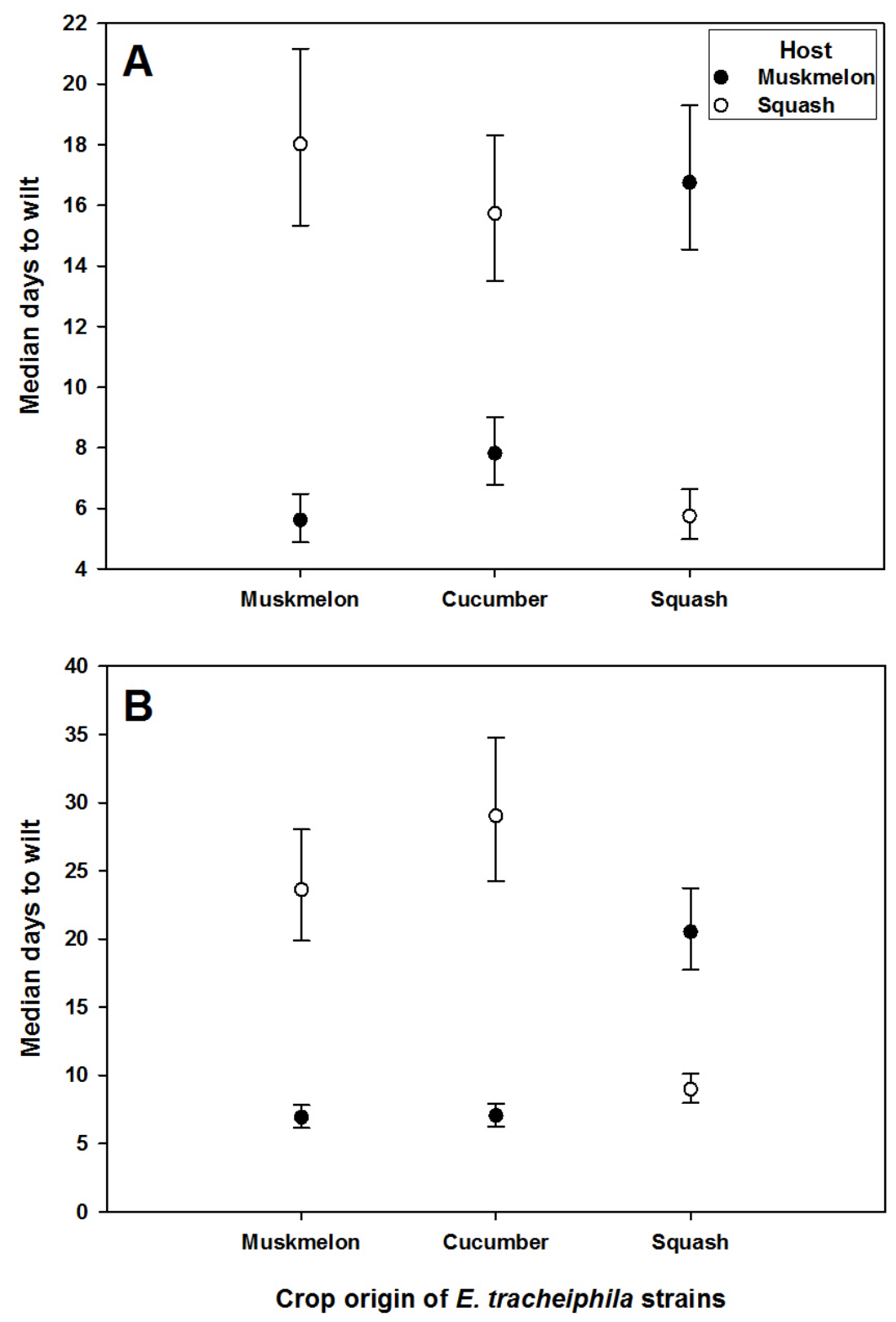

Figure 2. Interaction plots showing median days to wilt of muskmelon (cv. Athena) and yellow summer squash (cv. Early Summer Crookneck) host plants after artificial inoculation with E. tracheiphila strains isolated from naturally-infected cucurbit crops. The experiment was performed twice and each data point in A (first run of the experiment) and $\mathbf{B}$ (second run) represents the estimate and 95\% confidence interval 
(CI) for median days to wilt of 16 inoculated plants. CIs were calculated using the pooled variability among isolates within crop origin of strains. 


\title{
CHAPTER 5
}

\section{BEES, BEETLES, AND BACTERIA: THE CUCURBIT BACTERIAL WILT DILEMMA. AN EDUCATIONAL RESOURCE FOR UNDERGRADUATE EDUCATION.}

\author{
A manuscript submitted to Plant Health Instructor \\ Erika Saalau Rojas, Laura Jesse, and Mark L. Gleason
}

\section{Instructor Notes}

\section{Introduction}

This case study introduces students to a complex disease management situation in which a muskmelon farmer, Henry DeSoto, is facing pressure to change his management practices against cucurbit bacterial wilt. Cucurbit bacterial wilt is transmitted by striped cucumber beetles (Acalymma vittatum), and Henry relies on weekly or biweekly insecticide applications to control beetles. Beekeepers near Henry's farm are concerned that the large amount of insecticides that Henry is using on his cucurbit crops may be endangering the health of their honey bees. Unless Henry convinces the beekeepers that he has adopted alternative strategies that significantly reduce the use of insecticides in his farm, he may find himself in a lawsuit.

The cucurbit bacterial wilt case study will challenge students to weigh several integrated pest management (IPM)-based management strategies and provide potential solutions to Henry's problem. In this process, students will recognize some of the advantages and limitations of implementing IPM approaches on a commercial vegetable farm. 


\section{Objectives}

The goal of this case study is to challenge students to solve a disease management situation in the context of real world decision-making. Students will recognize that integrated pest management (IPM) is a holistic approach that needs to consider the cropping system, disease biology, economic factors, and surrounding landscape. In addition, this case study illustrates the role of an insect vector in transmission and dispersal of a plant pathogen.

After completing this case study, the student will:

- Recognize cucurbit bacterial wilt signs, symptoms, and vectors

- Comprehend the bacterial wilt disease cycle

- Identify practical limitations of managing an insect-transmitted disease in a beepollinated crop

- Evaluate advantages and limitations of IPM-based approaches

- Increase their awareness of Colony Collapse Disorder (CCD) of honey bees.

\section{Cast of characters}

Henry DeSoto: Cucurbit farmer who specializes in muskmelon production.

Deborah Kopper: Beekeeper and chairwoman of the local beekeeping association. She warns Henry that beekeepers blame the poor health of their bee hives on his heavy use of insecticides to control cucurbit bacterial wilt.

\section{Case Summary}

This case study is designed to challenge college-level undergraduate students in plant pathology, horticulture, and entomology fields to develop a management plan 
involving an insect-transmitted disease, cucurbit bacterial wilt. In addition to recognizing the vector, signs, and symptoms of this bacterial disease, students will also identify practical limitations involved in managing an insect-transmitted disease in a bee-pollinated crop. When Henry DeSoto, a local muskmelon grower, is accused of excessive insecticide use by beekeepers in the area, he fears that his reputation and economic viability will be damaged by the complaint. A potential solution is to develop an Integrated Pest Management (IPM)-based approach to reduce insecticide applications in his farm. Before choosing an alternative management strategy, however, students will have to formulate solutions to overcome some of the practical limitations for each strategy and evaluate the feasibility of implementing an IPM approach.

\section{Suggestions on how to use this case}

This case can be completed in either a 50-minute class period or a 90-minute laboratory session. In the former, Part A should be read by students before the class period. Background information about cucurbit bacterial wilt and colony collapse disorder can be presented in a previous class or assigned as a reading beforehand. In a longer class session, background information about cucurbit bacterial wilt and colony collapse disorder may be presented in class and followed by reading Part A of the case

study. Before proceeding to Part B of the case study, students should have discussed the introductory questions and should be familiar with the cucurbit bacterial wilt disease cycle and management practices.

During the first part of the lesson, the instructor can lead the discussion while answering the introductory questions. Students may share their opinion on whether or 
not Henry should fight the complaint made by beekeepers. At this point we suggest explaining what is known about colony collapse disorder, discussing bee protection rules, and the impact of agricultural practices on honeybees and pollinators. Students should discuss the remaining introductory questions and the instructor can finish with a review of the cucurbit bacterial wilt disease cycle and management strategies to control the disease.

After reading and discussing Part A, divide students into groups of 3 to 4 members. Each student should read and discuss Part B of the case study. The instructor should allow at least 30 minutes for groups to answer questions in Part B and write up a potential management plan. Each management plan should be presented to the whole class. The instructor and classmates should ask each group how they will overcome the limitations associated with each of the strategies. Additionally, each group should explain which factors influenced their decision-making process. In the case of row covers, cost of materials, labor, and timing of removal considerations should be discussed. For perimeter trap cropping, factors such as marketing of a new crop, effectiveness of the strategy, and practical limitations of handling two different crops should be discussed.

\section{Possible adaptations}

The case study "Bees, beetles, and bacteria: the cucurbit bacterial wilt dilemma" presents a storyline that can be adapted to fit into the program needs of plant pathology, horticulture, sustainable agriculture, entomology, integrated pest management, and plant health management majors. The case focuses on a complex disease management 
situation in which potential integrated pest management solutions are emphasized; however, other factors such as economic and social considerations should be examined by students before making a decision. A small amount of comparative cost data is presented in order to help students discuss economic tradeoffs. One or several of these aspects can be highlighted to engage students in discussions beyond basic plant pathology and management concepts.

In our experience in trying out the case, we found that undergraduate students in horticulture were particularly interested in learning more about pollinators and colony collapse disorder. This topic can be easily emphasized by assigning more readings about colony collapse disorder and the environmental effects of pesticides. Discussion could be enhanced by dividing a class into two groups: one representing Henry DeSoto, the muskmelon grower, and the other representing Deborah Kopper and the beekeepers. The groups could debate about the effects of pesticides on non-target insects, beekeeping management practices, and agricultural practices that could lead to poor bee colony health. A third group in the classroom could act as evaluators and decide which of the other groups made the more convincing argument to "win" the case.

Given the rapid increase of urban agriculture throughout the U.S., this case study can also be adapted to discuss the impact of insect and disease management practices in urban settings. Students could discuss some of the challenges associated with urbanization, such as high land prices, labor limitations, and restrictions on the use of pesticides, as well as some of the benefits, such as new marketing opportunities, support of local food systems, and promotion of food security and health awareness. 
In a similar context, social perceptions about pesticide use and insect and disease management strategies could be discussed. Students could investigate whether and how crop management practices and produce marketing strategies have changed due to public awareness of pesticide use and chemical residues.

\section{THE CASE: Bees, beetles, and bacteria: the cucurbit bacterial wilt dilemma}

\section{(PART A)}

A second-generation farmer, Henry DeSoto, has decided to specialize in muskmelon production in a fast- developing urban area. He farms approximately 40 acres, and is one of the few farmers left in the area. For the past 3 years, he has been selling muskmelon at local farmers markets. His profits are high, especially because he is very successful at harvesting his fruit early in the season, when prices are relatively high. His major production challenge is controlling cucumber beetles and the deadly disease that they carry: bacterial wilt.

Henry has experienced how damaging bacterial wilt outbreaks can be. One year, he was too late in controlling the beetles and lost $80 \%$ of his crop. Ever since, he takes no chances and controls the beetles with a systemic neonicotinoid insecticide at planting and insecticide sprays throughout the season. Some farmers monitor the beetle populations in their fields and use scouting thresholds for cucumber beetles to decide whether they need to spray their crop or not; but beetle populations are hard to predict and it takes a lot of time to scout. Henry feels he is too busy to scout; instead, he prefers 
to see dead cucumber beetles after spraying insecticides. Henry’s insecticide-based approach means that he makes at least eight insecticide applications per season.

One October evening, Henry receives a call from Deborah Kopper, a commercial beekeeper who is heavily involved with agriculture in the local community. Deborah has kept bee hives for 15 years and is chairwoman of the beekeeping association in the county. There are 25 beekeepers across the county, and three of them are located within a mile of Henry's farm.

Deborah mentions that there is a major concern about the number of insecticide applications he’s been using in his crop. “Some beekeepers are noticing that their hives are not doing very well, and they're blaming you for excessive insecticide use”, Deborah says.

Henry has heard rumors about beekeepers pointing fingers at farmers for endangering bee health, but he decides to sound calm and confident. "Deborah, I'm using the latest vegetable pest control recommendations from the state university, and all my products are labeled for cucurbit use, so I don't need to apologize for anything I'm doing.” Henry replies.

“Well, Henry, I can’t stop you... yet. But I thought I’d give you a friendly warning before we file a legal complaint. The latest scientific research supports our claims. We now know that insecticides pose a risk to foraging bees, bee hive health, and other beneficial insects. Have a good day.”

A couple of days later, Henry received a letter from a lawyer stating that a lawsuit had been filed. The document stated that Henry's management practices are 
detrimental to bee and colony health and that at least three beekeepers are suffering economic losses due to massive die-offs of bees in their hives. Henry had hoped that Deborah's call had been a bluff, but he now realizes that this issue will require his immediate attention. He already knew that using less pesticide could be a way to avoid complaints from neighbors, but he hadn't seen the urgency of changing his ways until now.

Henry was upset. He thought, “I did nothing legally wrong! I don’t think there’s that much research that points to insecticide use as being the main factor involved in poor bee hive health, but things tend to get more serious when economic losses are brought up.” Henry thinks about hiring a lawyer but he knows that lawsuits are timeconsuming and very expensive. Even if he wins this lawsuit, Henry will have to deal with all the bad publicity and being called a 'bee killer'. This may cause his customers to question his use of pesticides and decide to stop buying his produce at the market.

A week later, Deborah calls again. She wants to help Henry, but his use of pesticides has put them both in a difficult situation. "If you are willing to consider using less insecticide”, Deborah says, "I'll set up a mediation meeting with the beekeeping association. But if you decide to have this meeting, Henry,” Deborah warns him firmly, "we expect to hear a detailed management plan against cucurbit bacterial wilt that dramatically cuts your use of insecticides.”

What should Henry do?

\section{Questions}


1. What is the role of cucumber beetles in this disease system? Does this role change your view of the disease triangle? Why or why not?

2. What are the signs and symptoms of cucurbit bacterial wilt?

3. Describe the cucurbit bacterial wilt disease cycle.

4. Can bacterial wilt be controlled by using fungicides or antibiotics? Why?

5. What do you think about Henry’s statement: “'I did nothing legally wrong!”? Can the beekeeping association prove that he is responsible for poor health of the bees in their hives?

\section{THE CASE: Bees, beetles, and bacteria: the cucurbit bacterial wilt dilemma (PART B)}

Henry searches the internet to obtain more information about cucurbit bacterial wilt. He knows that he will not be able to control cucumber beetles effectively if he eliminates all insecticide applications, but he is willing to consider insecticide reduction strategies as part of an Integrated Pest Management (IPM) plan. An IPM approach relies on combining management strategies to effectively control a pest while minimizing human health and environmental risks. Unfortunately, there is not a standard IPM plan against bacterial wilt, so Henry will have to choose which strategies could be applicable to his farm and resources.

With this goal in mind, Henry skims several extension publications. He is surprised to find out that cucumber beetle populations fluctuate throughout the season he had never paid that much attention to their activity patterns. According to the 
publications, the first flush of beetles is made up of adults that have survived the winter buried about 1 inch deep in the soil, then emerged from warming soil and started flying early in the spring, about the same time he is planting his muskmelon crop. These beetles carry the wilt bacterium, Erwinia tracheiphila, in their guts; when they feed on cucurbit plants and deposit frass (fecal pellets), the bacteria can invade and infect the young cucurbit plants through the beetle feeding wounds. Later in the spring, the second flush of beetles corresponds to newly hatched adults, but to Henry's surprise, they do not carry the cucurbit bacterial wilt pathogen - at least not at first. In order to acquire and spread the bacterium, cucumber beetles that hatch during the growing season must first feed on infected plants.

It's clear to Henry that in order to control bacterial wilt he has to minimize the contact between the first flush of cucumber beetles and his young melon plants by creating some sort of barrier.

Henry explores the possibility of using row covers. Row covers are made of a special breathable polypropylene fabric. This fabric allows light and air to go through but protects plants from insects as well as harsh weather conditions like frost, hail, and high winds. Row covers can keep out cucumber beetles and bacterial wilt very effectively. As an added bonus, row covers may protect plants from diseases caused by fungi, and can save Henry several fungicide sprays. However, row covers have some drawbacks: they are costly to buy and laborious to put on and take off. Another concern is when to remove row covers. If row covers are left in place through the entire muskmelon season, Henry can eliminate most insecticide applications and protect his 
crop. On the other hand, cucurbit crops are $100 \%$ bee-pollinated; if plants are covered by row covers, how will the bees pollinate them? Unless Henry solves the problem of when to remove the row covers, pollination could be delayed (resulting in a late harvest) or yield could be reduced.

A second strategy that Henry learns about is called perimeter trap cropping (PTC). The principle behind perimeter trap crops is to keep the cucumber beetles out of one crop (called the main crop) by providing a more beetle-attractive alternative crop as a barrier (or perimeter) around the main crop. Often, the trap crop border consists of two rows of the trap crop planted on the outer edge of the main crop field. In Henry's case, the main crop would be muskmelon. The trap crop keeps cucumber beetles from entering the main crop because they enter the field from its borders and tend to remain on these highly attractive plants. The beetles that congregate in the trap crop can be killed by spraying the border rows with insecticide. Henry reads that in winter squash, using PTCs can eliminate up to $90 \%$ of insecticide applications, because the main crop needs fewer insecticide sprays than a non-PTC main crop. However, this strategy has not been tested using muskmelon as the main crop and he is concerned that the bee keepers might object to insecticides around the edge. Henry is not sure how honey bees forage and if they would be likely to start foraging at the edge first. Some references list several varieties of winter squashes that could be used as a perimeter trap crop for muskmelon, but Henry is not familiar with these crops and does not know if his customers will be interested in buying these squash varieties. The trap crop must also be planted 2 weeks before the main crop, which means Henry will have to work around the 
trap crop when he decides to plant the muskmelon. Is it worth trying this strategy? If the perimeter trap crop is not successful, he may have a perimeter of bacterial wilt-infected plants surrounding his main crop.

Henry's mind is whirling with possibilities. All of these strategies sound promising, but how can he overcome the practical limitations associated with each strategy? Should he come up with his own plan or combine strategies?

In order to decide which alternatives are economically feasible, Henry pencils out a chart of additional costs per acre associated with each of the strategies he just read about, including the cost of scouting per acre:

\section{Perimeter trap crop}

\section{Scouting}

Row covers

(PTC)

\begin{tabular}{lccc}
\hline Materials & $\$ 1,300.0$ & $\$ 20.0$ & $\$ 0.0$ \\
Labor & $\$ 700.0$ & $\$ 1,500.0$ & $\$ 4.0$ \\
\hline
\end{tabular}

Henry's current management plan against cucumber beetles:

Insecticide applications

Neonicotinoid insecticide (at transplant)

\section{Cost per acre}

$\$ 80.0$ 
Carbamate or pyrethroid insecticide (weekly or biweekly) $\quad \$ 8.0$

If you were advising Henry, what would you recommend that he do?

\section{Questions}

1. Based on your knowledge of cucurbit bacterial wilt, in which part(s) of the growing season do you think that risk of wilt infection is highest? Why?

2. Discuss potential solutions to the potential problem of delaying harvest (and possibly receiving lower prices per fruit as a result) while using row covers.

3. What are some practical challenges that need to be overcome when implementing a perimeter trap crop?

4. In order for a perimeter trap cropping system to be successful against bacterial wilt, which characteristics are desirable in the perimeter plants? Hypothesize what could go wrong if Henry chooses an inappropriate cucurbit variety for his perimeter.

5. Use all of the information available and your own experiences to construct an IPM-based management plan against cucurbit bacterial wilt that could solve Henry’s situation.

6. When choosing among different IPM strategies to combat pests and diseases, what kind of considerations do you think farmers will keep in mind when making a decision? 


\section{Background information}

\section{Cucurbit bacterial wilt (PART A)}

Cucurbit bacterial wilt is a disease that affects economically important crops

such as melon, cucumber, and squash.

The bacterium that causes this disease, Erwinia tracheiphila, is transmitted by striped cucumber beetles (Acalymma vittatum) (Fig. 1) and survives winter in the beetles' digestive systems. Infection occurs when bacteria-infested beetles chew on young cucurbit plants and deposit bacteria-infested frass (feces) onto fresh feeding wounds on leaves and stems. Once E. tracheiphila enters the plant, bacteria multiply and clog up the vascular system, causing plants to appear water-stressed and wilted (Fig. 2). Infected plants start showing symptoms 1 to 3 weeks after infection. As infection progresses, plant tissues collapse and die before yielding any fruit (Fig. 3).

A diagnostic test to determine whether a plant is infected with bacterial wilt can be done in the field. A wilting vine can be cut with a sharp knife. The cut ends are then slowly pulled apart; if bacteria are present, threads of bacterial 'ooze’ can be seen attached from both ends (Fig. 4).

The disease cycle begins when overwintering adult beetles become active in spring. Cucumber beetles are highly attracted to young cucurbit plants and they may infest a cucurbit field less than 24 hours after seedling emergence or transplanting. The risk of infection by Erwinia tracheiphila is highest during the spring, when beetle populations are elevated and plants are more susceptible. 
Once in a cucurbit field, overwintering beetles feed and mate. Females lay their eggs at the base of cucurbit plants. Cucumber beetle larvae feed on the roots of the plants, pupate and several weeks later emerge as adult beetles. This first generation of beetles can re-acquire the pathogen by feeding from bacterial wilt-infected plants and continue the spread of E. tracheiphila to healthy plants. Up to 2 or 3 generations of beetles may be observed in a single season depending on the region. Late in the season, cucumber beetles seek overwintering sites near the field and begin the disease cycle next spring.

For more information about cucurbit bacterial wilt, university extension bulletins can be found online.

\section{What is Colony Collapse Disorder (CCD)?}

In 2006, an unexplained loss of worker bees in honey bee hives was noticed among beekeepers across the United States. This mysterious disappearance affected 30 to $90 \%$ of bee colonies - an alarmingly high rate of loss. It was particularly puzzling to scientists that the hives affected showed no obvious signs of disease, and that the dead bodies of the missing bees were nowhere to be found. This phenomenon of missing bees is referred to as Colony Collapse Disorder (CCD).

In the past few years, CCD has received at lot of attention from researchers, industry, media, and the general public because it represents a huge threat to agriculture. Honey bees provide pollination services to about 130 different crops in the U.S.A. and it is estimated that bees help produce about 1/3 of the food that we eat (Fig. 10).

\section{Potential causes of CCD}


Several pathogen and parasite infections have been blamed for CCD. The fungus Nosema ceranea, Varroa mites, and viral infections (i.e. Israeli Acute Paralysis Virus) have been frequently associated with CCD colonies. Some studies have correlated the occurrence of two or more pathogens or parasites with CCD colonies; however, it is unclear to researchers whether these infections cause CCD themselves, or weaken colonies so that they are more vulnerable to other sources of stress.

Poor bee hive management practices and environmental stressors have also been pinpointed as possible causes of CCD. Commercial bee hives can often be overcrowded and as a consequence bees may become undernourished and stressed. Other factors involved may be frequent migration and shipping of bee hives across the country to provide pollination services in high value crops. Bee hives are often rented and may travel thousands of kilometers in a single season, resulting in prolonged disturbance of colonies.

Some researchers consider that habitat changes may also act as stressors. Disturbance in the landscape, for example caused by urbanization and intensive agricultural systems, could contribute to bee population decline by limiting the availability of food and water for foraging bees.

Among the many suspects in the CCD mystery, insecticide exposure is probably the most controversial topic. Several recent research reports demonstrated that exposure to a specific family of insecticides, called neonicotinoids, could be linked to bee die-offs and CCD. Even at sublethal doses, neonicotinoids can disorient bees and weaken 
colonies, possibly making them more prone to CCD. However, scientists have not provided a direct correlation between neonicotinoid exposure and CCD.

\section{Recommendations to growers, beekeepers, and general public}

Although fingers have been pointed at numerous causes, scientists seem to agree that CCD is most likely the result of a combination of the above-mentioned factors. However, research is ongoing and over the next few years we can hope for a clearer explanation of CCD. In the meantime, recommendations for beekeepers are to use management practices that enhance honey bee health and improve their habitat.

For the general public and farmers, USDA and EPA recommend limiting the use of pesticides by implementing Integrated Pest Management and avoid applying pesticides during mid-day. For more information about research directions and recommendations visit USDA (http://www.ars.usda.gov/News/docs.htm?docid=15572) and EPA (http://www.epa.gov/opp00001/about/intheworks/honeybee.htm) websites.

\section{Managing cucurbit bacterial wilt (PART B)}

Cucurbit bacterial wilt can be a difficult disease to control. Erwinia tracheiphila, the causal agent, is harbored and spread by cucumber beetles (Fig. 5). Unlike other bacterial diseases, cucurbit bacterial wilt infections cannot be stopped by using copper sprays or other chemicals. Infected plants usually die a couple of weeks after showing wilt symptoms. A second challenge in managing this disease is the lack of commercial cucurbit varieties resistant to bacterial wilt. Therefore, control of cucurbit bacterial wilt relies on managing cucumber beetles to prevent infection. Some conventional and cultural practices are listed and explained below: 


\section{Chemical control}

Contact insecticides (i.e., those that have their effect by coming into direct contact with target insects in the environment or on the outside surfaces of plants) such as carbamates or synthetic pyrethroids can be effective against cucumber beetles but need to be applied every 4 to 5 days when beetle populations are high. Neonicotinoids, a widely used family of systemic insecticides (systemic insecticides enter tissues of crop plants, where they can deter insect feeding or other behaviors), are highly effective and are usually applied at transplant. Soil applications of neonicotinoids can protect young plants for as long as 3 to 5 weeks after application. Cucurbit farmers often use neonicotinoids at the beginning of the season and follow up with weekly or biweekly applications of contact insecticides the rest of season. For more information about approved products to control cucumber beetles regional vegetal production guides for commercial growers can be accessed online (e.g.

http://www.btny.purdue.edu/pubs/id/id-56/ID-56.pdf).

Weekly or biweekly scouting for cucumber beetles is recommended. Insecticides should be applied if 1 beetle/plant is found.

\section{Row covers}

Row covers are made of non-woven polypropylene material often used to protect young plants from harsh weather conditions and insect pests. Row covers can act as a physical barrier against cucumber beetles when placed over cucurbit seedlings immediately after planting or emergence (Fig. 6). 
Installation of row covers is expensive and labor-intensive. Row covers are deployed over wire hoops placed every 2-3 feet and the ends need to be tightly secured by weighing down or burying the edges into the ground (Fig. 7). At anthesis, the start of female bloom (Fig. 8), pollination needs to be enabled to avoid harvest delays. Different timing of removal strategies and information about row covers can be found at: http://www.ipm.iastate.edu/ipm/hortnews/2011/2-9/rowcover.html

\section{Perimeter trap crops (PTC)}

The principle behind PTC relies on using a perimeter of plants that act as a barrier to protect a main crop, called a cash crop, from insect pests such as cucumber beetles. The advantage of using a PTC is that it limits the amount of insecticide to a much smaller area, since most or all insecticide sprays target only the perimeter around the main crop.

In order for a PTC to work, a cucurbit crop that is much more enticing to cucumber beetles than the main crop should be used in border rows surrounding the main crop. The PTC should also be less susceptible to bacterial wilt than the main crop, and preferably should not compete with the main crop. Field research has shown that PTCs are more effective when 1 to 3 rows are planted around the main crop, and trap crop planting should be timed before or right at the time of planting of the main crop (Fig. 9). The PTC and the main crop should be scouted on a regular basis, about 2 to 3 times per week, to verify that cucumber beetles have not moved into the main crop. A threshold of 1 beetle/plant triggers insecticide sprays when the risk of bacterial wilt is high. 
Several factors should be considered before implementing PTC. Using a PTC means that some percentage of the farm acreage will be dedicated to a crop that is different from the main crop. For example, certain winter squash varieties can be used to protect a main crop of muskmelon, but this arrangement means that farmers will often have to manage two somewhat different sets of diseases and pests, harvest the two crops at different times, and market two different types of produce. Although using PTC has been successful in squash crops, its effectiveness is still being researched in muskmelon and cucumber crops. For more information about the use of PTC against cucumber beetles and bacterial wilt, please consult the Organic Cucurbit Growing community website at http://organiccucurbit.plp.iastate.edu/.

\section{Instructor Answer Key}

\section{Part A}

\section{What is the role of cucumber beetles in this disease system? Does this role} change your view of the disease triangle? Why or why not?

The disease triangle is a basic plant pathology concept that illustrates the interaction of three factors required for biotic disease to occur: a susceptible host, an infectious pathogen, and a favorable environment for disease development. Although this concept may be applied to most infectious diseases, it fails to represent the role of insects as pathogen vectors. Erwinia tracheiphila, the causal agent of cucurbit bacterial wilt, is overwintered and transmitted by cucumber beetles. Without bacteria-infested beetles; a bacterial wilt epidemic is 
unlikely. Students may argue that striped cucumber beetles are implicitly represented in the disease triangle or may suggest adding a fourth factor, the vector, as a critical component. Students may suggest adding a link between the pathogen and the host to maintain a linear format for the disease triangle. A three-dimensional representation of the disease triangle may also be acceptable by drawing an additional vertex to the triangle and converting it into a disease pyramid. More variants may be discussed among students and as long as the main factors for disease development are accounted for all answers should be correct.

\section{What are the signs and symptoms of cucurbit bacterial wilt?}

Signs: bacterial 'ooze'

Symptoms: wilting of leaves and vines followed by necrosis

\section{Describe the cucurbit bacterial wilt disease cycle.}

The bacterial wilt disease cycle is closely linked to the striped cucumber beetle life cycle. Primary inoculum comes from adult overwintering beetles harboring bacteria in their digestive systems. Beetles become active in spring and seek cucurbit plants to feed on. Transmission of the pathogen occurs when bacteriainfested beetles feed on plant tissues and deposit bacteria-infested frass (feces) onto fresh feeding wounds. Once inside the plant's vascular system, bacteria multiply and clog the xylem, which leads to wilting of leaves and vines 1 to 3 weeks after infection. Subsequently, plant tissues collapse and the plant dies. 
Overwintering beetles feed and mate in cucurbit fields and females lay their eggs at the base of cucurbit plants. Cucumber beetle larvae feed on roots, pupate, and emerge in the field. Newly emerged beetles do not harbor Erwinia tracheiphila, but they may acquire and spread the pathogen by feeding on infected plants. Depending on the region, multiple generations of beetles may be observed in a single season. Later in the season beetles seek overwintering sites near fencerows and plant debris and if they harbor the pathogen in their guts, the disease cycle will begin next spring.

\section{Can bacterial wilt be controlled by using fungicides or antibiotics? Why?}

No, bacterial wilt cannot be controlled by fungicides or antibiotics because Erwinia tracheiphila is a vascular pathogen. Once a plant is infected it cannot be cured and should be removed. Control of bacterial wilt relies on preventing infection by controlling cucumber beetles.

10. What do you think about Henry's statement: “'I did nothing legally wrong!"? Can the beekeeping association prove that he is responsible for poor health of the bees in their hives?

It is unlikely that that the beekeeping association will be able to blame Henry for their problems because he is following regional pesticide recommendations to control cucumber beetles. In addition, many factors have been implicated in poor honey bee health problems and there is no evidence pointing to a single factor. However, Henry's statement may lead to a discussion about what is known about 
colony collapse disorder and whether it is advisable to pursue a lawsuit. Some points that may be considered for discussion in class could be the following:

- A lawsuit is expensive and time consuming. Students may evaluate whether it is worth Henry's resources to pursue a lawsuit against beekeepers. Although there might not be enough evidence to support the beekeepers claims, it may take months or years to reach an agreement. In addition, a lawsuit involving pesticides can attract detrimental publicity and may deter local clients from buying Henry’s produce.

- Beekeepers are located a mile away from Henry’s farm. State departments of agriculture across the U.S.A. have an array of rules that strive to regulate and protect honey bees. In Iowa for example, students discussed Henry's and the beekeepers’ compliance with the Iowa Department of Agriculture and Land Stewardship (IDALS) “Pesticide/Bee Rule”. In other states discussion points could revolve around apiary registration laws, commercial applicator distance from apiary, and timing of pesticide applications.

- Farmer awareness and responsibility. Government agencies (EPA, USDA, U.S. Wildlife Service) and universities invest many resources to encourage farmers and the general public to decrease pesticide use which could potentially harm pollinators. Calendar-based pesticide applications are often discouraged, and instead, agencies advocate for integrated pest management (IPM) strategies that reduce chemical applications in the 
environment. Although Henry might not be breaking any laws, do his practices pose a threat to pollinators? This dilemma may be brought up in the classroom to discuss whether Henry should be more conscious about his pesticide use and whether implementing IPM strategies should be an ethical responsibility for farmers.

\section{Part B}

1. Based on your knowledge of cucurbit bacterial wilt, in which part(s) of the growing season do you think that risk of wilt infection is highest? Why?

Bacterial wilt risk is highest during early spring, since overwintering bacteriainfested beetles serve as the source of primary inoculum. In addition, overwintering beetles become active in spring, around the same time when cucurbit fields have been recently planted or transplanted. Young seedlings are highly attractive to cucumber beetles and are more susceptible to bacterial wilt and insect damage (Fig. 11).

2. Discuss potential solutions to the potential problem of delaying harvest (and possibly receiving lower prices per fruit as a result) while using row covers.

Pollination can be enabled while using row covers by several methods:

- Removing row covers during female flowering (anthesis) to allow pollination and place row covers over plants until harvest.

- Placing bee hives under row covers at anthesis (Fig. 12)

- Other methods such as opening the ends at anthesis can effectively protect plants from cucumber beetle damage and bacterial wilt (Fig. 13). 
However, it is unclear why this method enables insect pollinator access under row covers and deters cucumber beetles.

\section{What are some practical challenges that need to be overcome when} implementing a perimeter trap crop (PTC)?

- PTC's should be planted earlier than the main crop, which could interfere with planting practices for the main crop.

- Management of two different crops may be expensive and knowledgeintensive. Pests and diseases will differ between the main crop and the PTC, which requires farmers to employ multiple management practices to prevent PTC failure. This may result in additional costs and labor.

- Produce marketing. Produce harvested from PTC may require different marketing channels, which may be a limitation for farmers with an established clientele or limited marketing opportunities.

\section{In order for a perimeter trap cropping system to be successful against} bacterial wilt, which characteristics are desirable in the perimeter plants? Hypothesize what could go wrong if Henry chooses an inappropriate cucurbit variety for his perimeter.

Higher attractiveness to cucumber beetles than the main crop, low disease susceptibility, and high marketability of produce.

1) Attractiveness: the PTC crop must be more attractive to cucumber beetles than the main crop. Otherwise the PTC, traditionally planted before the main crop, could serve as a lure to attract beetles around the main crop. If the main 
crop is more enticing to beetles, they could easily move into the main crop from the perimeter.

2) Low disease susceptibility: since a PTC serves as a barrier, the crop must be hardier than the main crop and less susceptible to bacterial wilt. A highly susceptible crop or variety could serve as source of inoculum for the main crop.

3) Marketability: some commercial and wild cucurbit species are highly attractive to cucumber beetles and have a high tolerance to bacterial wilt infection. However, low yield or poor acceptance of the product by clients makes these species non-profitable choices for PTC.

\section{Use all the information available and your own experiences to construct an} IPM-based management plan against cucurbit bacterial wilt that could solve

\section{Henry's situation.}

\section{Row covers}

- Deploy row covers at transplant and choose one of the following:

o Insert bees under covers at anthesis. In our classroom experience some students suggested reaching an agreement with the beekeepers to use their hives in Henry’s farm.

o Remove row covers during anthesis, protect exposed plants with insecticides, and reapply row covers until the end of the season.

o Open ends of row covers at anthesis to enable pollinator access 
o Remove row covers at anthesis to enable pollination and spray insecticides triggered by scouting the field 2 to 3 times per week. Although this might reduce insecticide use from transplant until anthesis (average of 4 to 5 applications), insecticides may have to be used weekly after row cover removal if beetle populations are too high.

\section{Perimeter trap crops}

- To reduce the risk of PTC failure Henry might one to try one of the following or a combination of the following strategies:

o Biweekly scouting in the PTC and main crop and spray at 1 beetle/plant

o Spray the PTC weekly (less insecticide applied per area)

o Use the same cucurbit species used in PTC squash systems

o Try different cucurbit varieties in different parts of the farm

o Plant a muskmelon PTC earlier than the main crop

o Double the amount of recommended PTC area to avoid risk of bacterial wilt infection

\section{When choosing among different IPM strategies to combat pests and} diseases, what kind of considerations do you think farmers will keep in mind when making a decision?

- Cost of the strategy and profitability

- Effectiveness of the strategy 
- Practical considerations such as availability of land, labor, materials, and technology

\section{References}

Cavanagh, A.F., Adler, L.S., Hazzard, R.V.2010. Buttercup squash provides a marketable alternative to blue hubbard as a trap crop for control of striped cucumber beetles (Coleoptera: Chrysomelidae). Environ Entomol. 39:1953-60.

Hopwood, J., Vaughan, M., Shepherd, M., Biddinger, D., Mader, E., Hoffman Black S., Mazzacano, C. 2012. Are neonicotinoids killing bees? The Xerces Society for Invertebrate Conservation. Available at: http://www.xerces.org/neonicotinoids-andbees/. (Accessed February 2, 2013).

Saalau Rojas, E., Gleason, M. L., Batzer, J. C., and Duffy, M. 2011. Feasibility of delaying removal of row covers to suppress bacterial wilt of muskmelon (Cucumis melo). Plant Dis. 95:729-734.

Stoner, K.A., Eitzer, B.D. 2012. Movement of Soil-Applied Imidacloprid and Thiamethoxam into Nectar and Pollen of Squash (Cucurbita pepo). PLoS ONE 7(6): e39114. doi:10.1371/journal.pone.0039114 
Figures

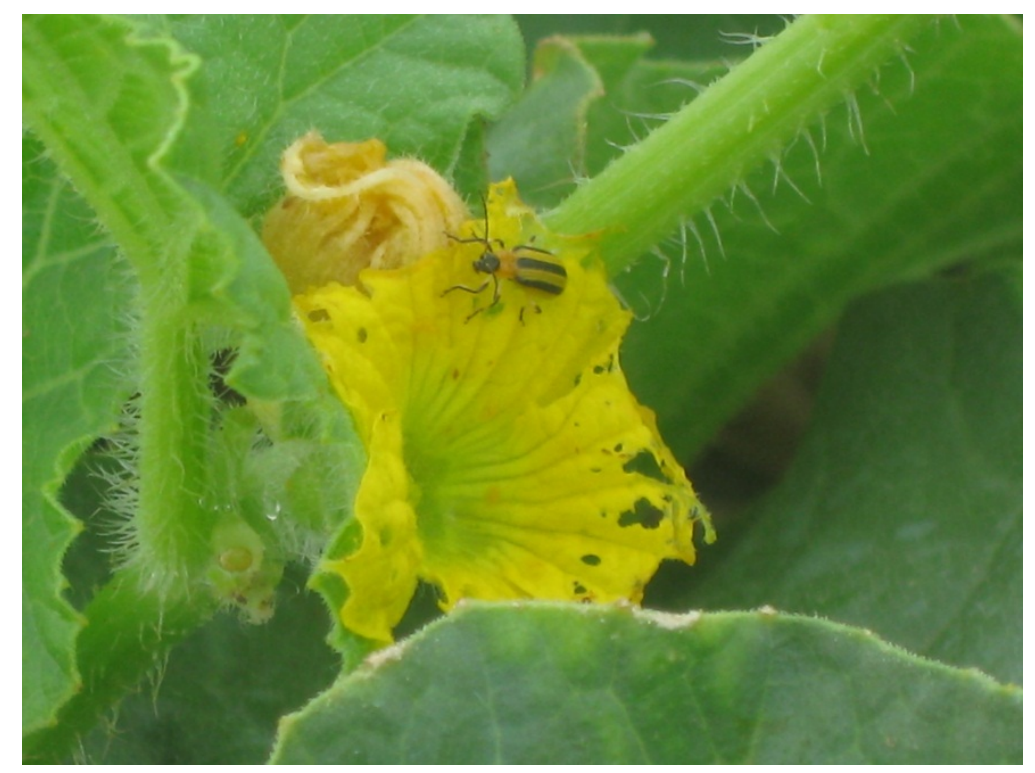

Figure 1. Striped cucumber beetles (Acalymma vittatum) overwinter and transmit the cucurbit bacterial wilt pathogen Erwinia tracheiphila. Photograph courtesy J.B Batzer.

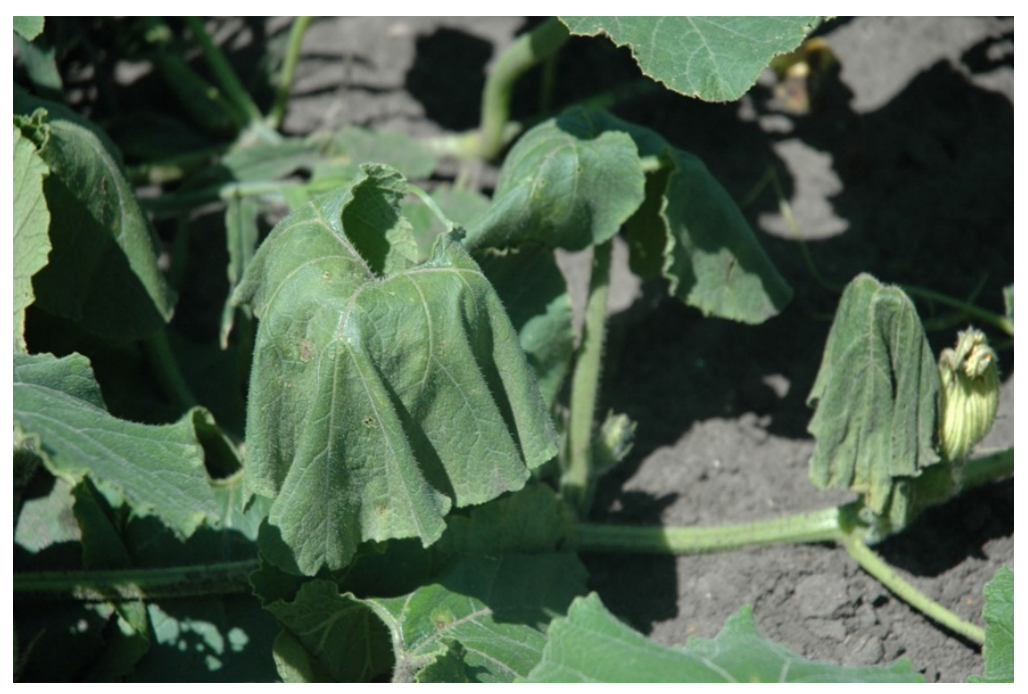

Figure 2. Cucurbit bacterial wilt symptoms. Photograph courtesy J.B Batzer. 


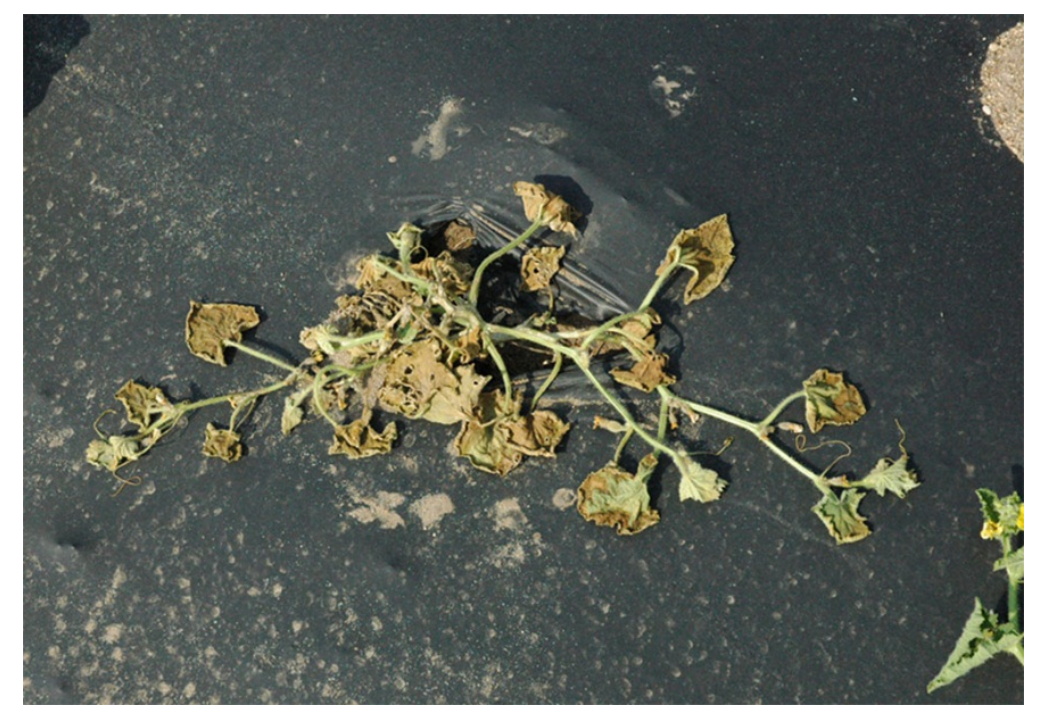

Figure 3. As infection progresses, infected plants collapse and die.

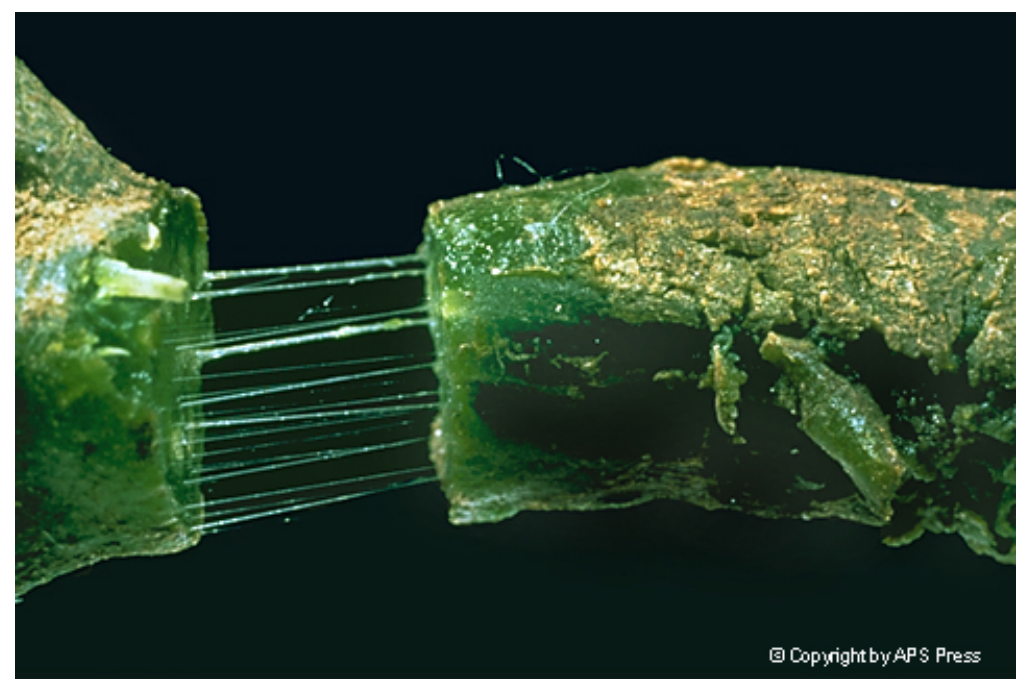

Figure 4. Bacterial wilt, caused by Erwinia tracheiphila. Sticky strand test on cut stems, with bacterial slime streaming from xylem tissues. Photograph courtesy M. P. Hoffmann from the Compendium of Cucurbit Diseases. 


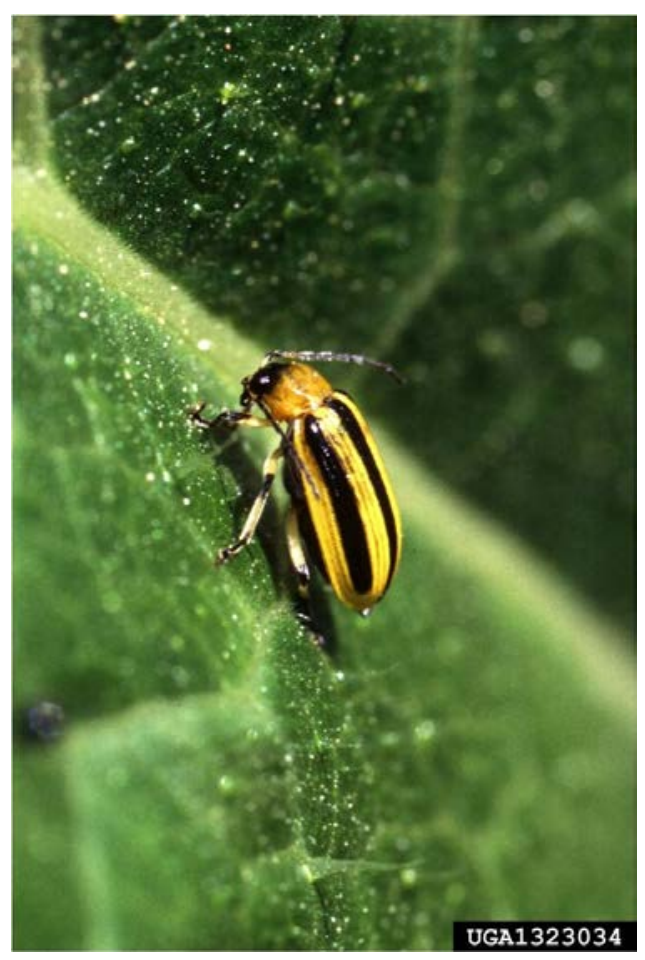

Figure 5. Striped cucumber beetle (Acalymma vittatum). Photograph courtesy Whitney Cranshaw, Colorado State University, Bugwood.org

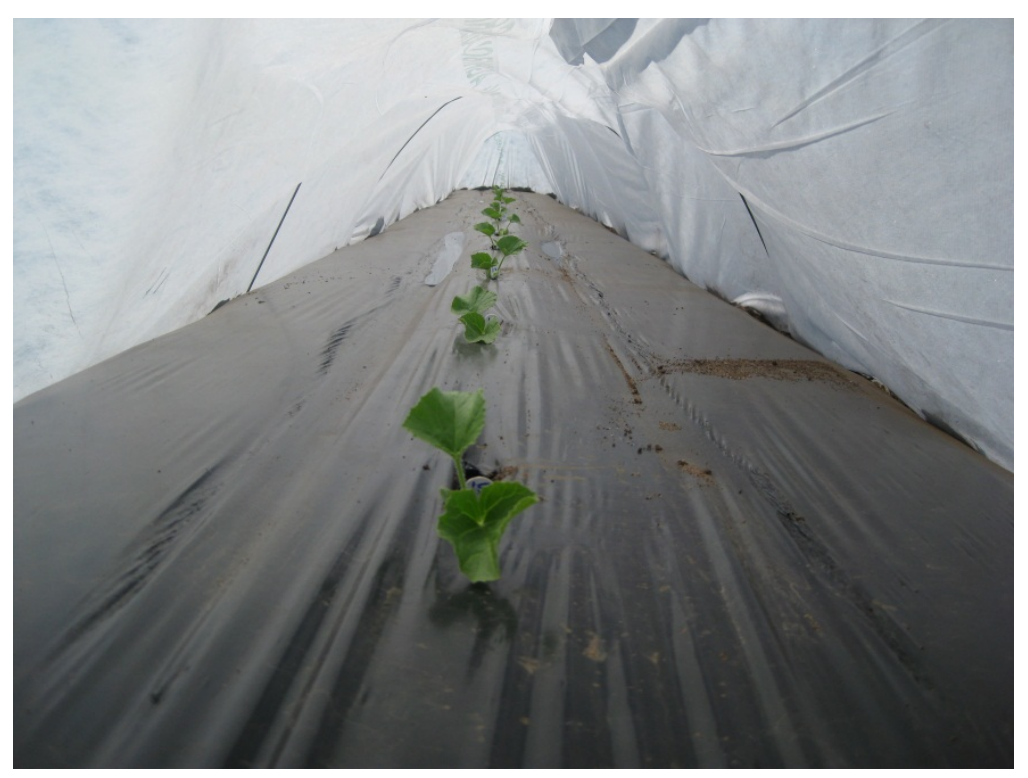

Figure 6. Row covers create a microenvironment that protects seedlings from harsh weather conditions and insect damage. 


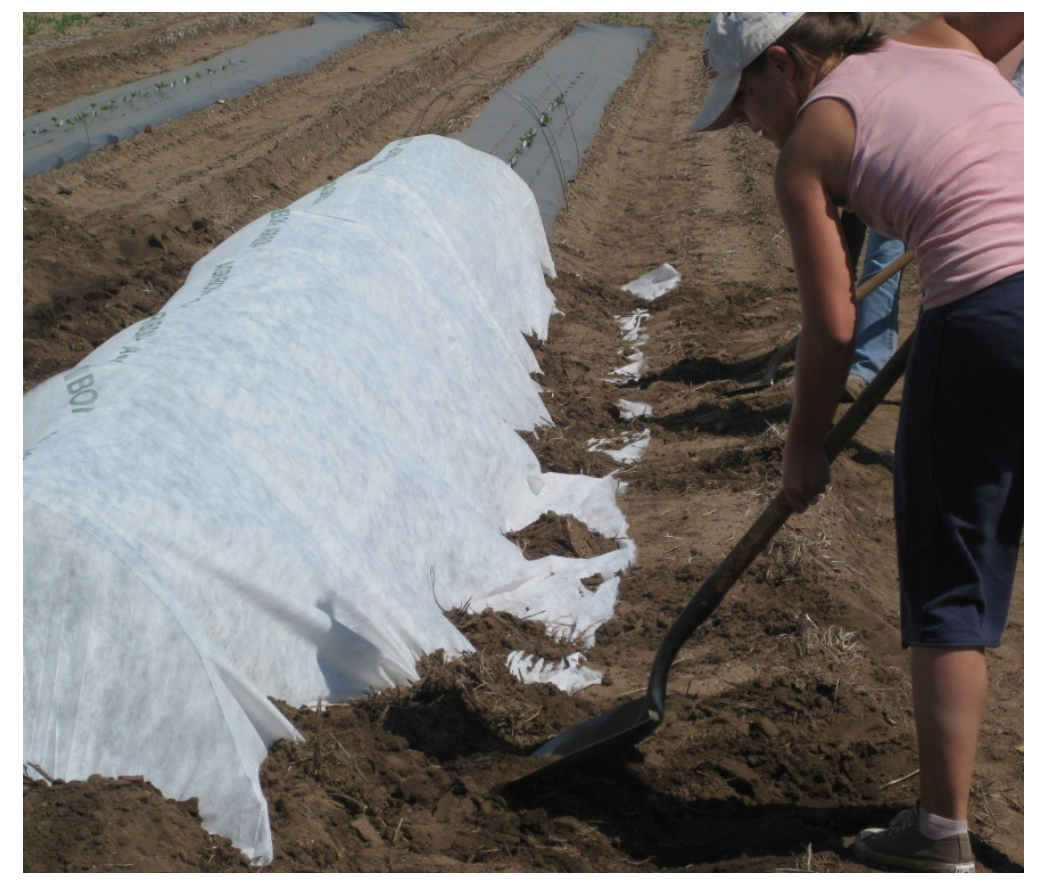

Figure 7. Row covers must be installed over wire hoops and the edges must be secured to prevent openings for beetles and tears due to wind.

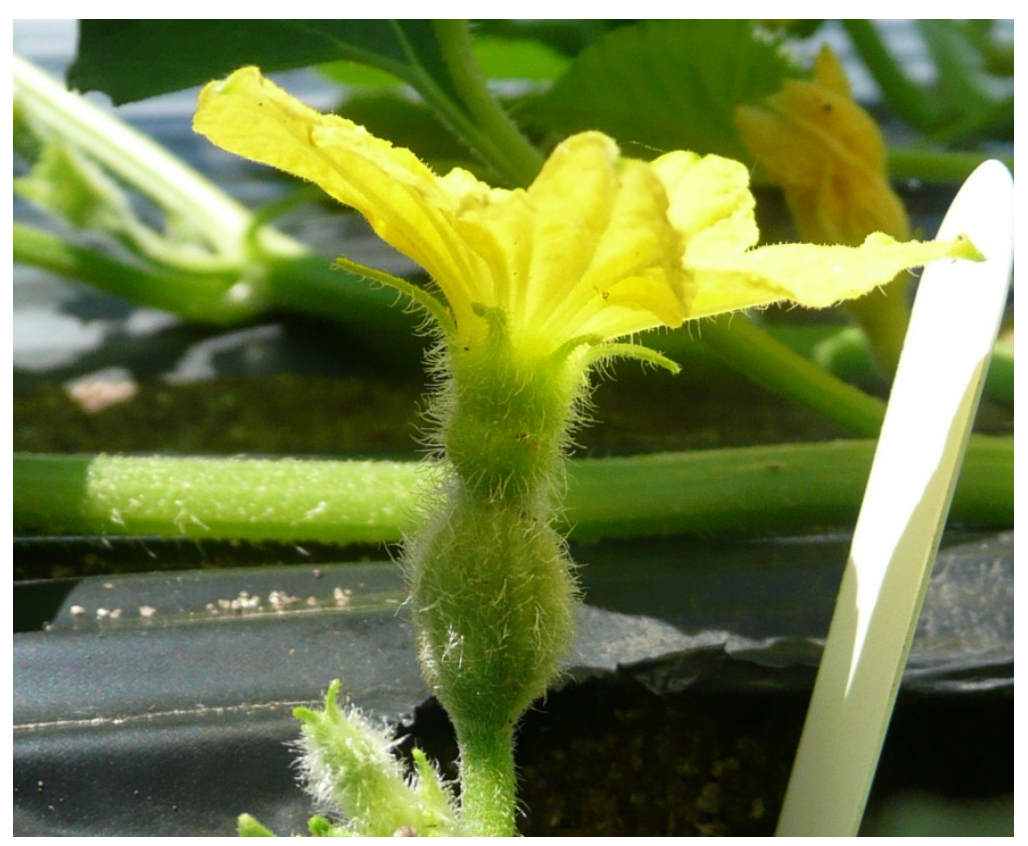

Figure 8. Muskmelon anthesis is the appearance of female flowers. 


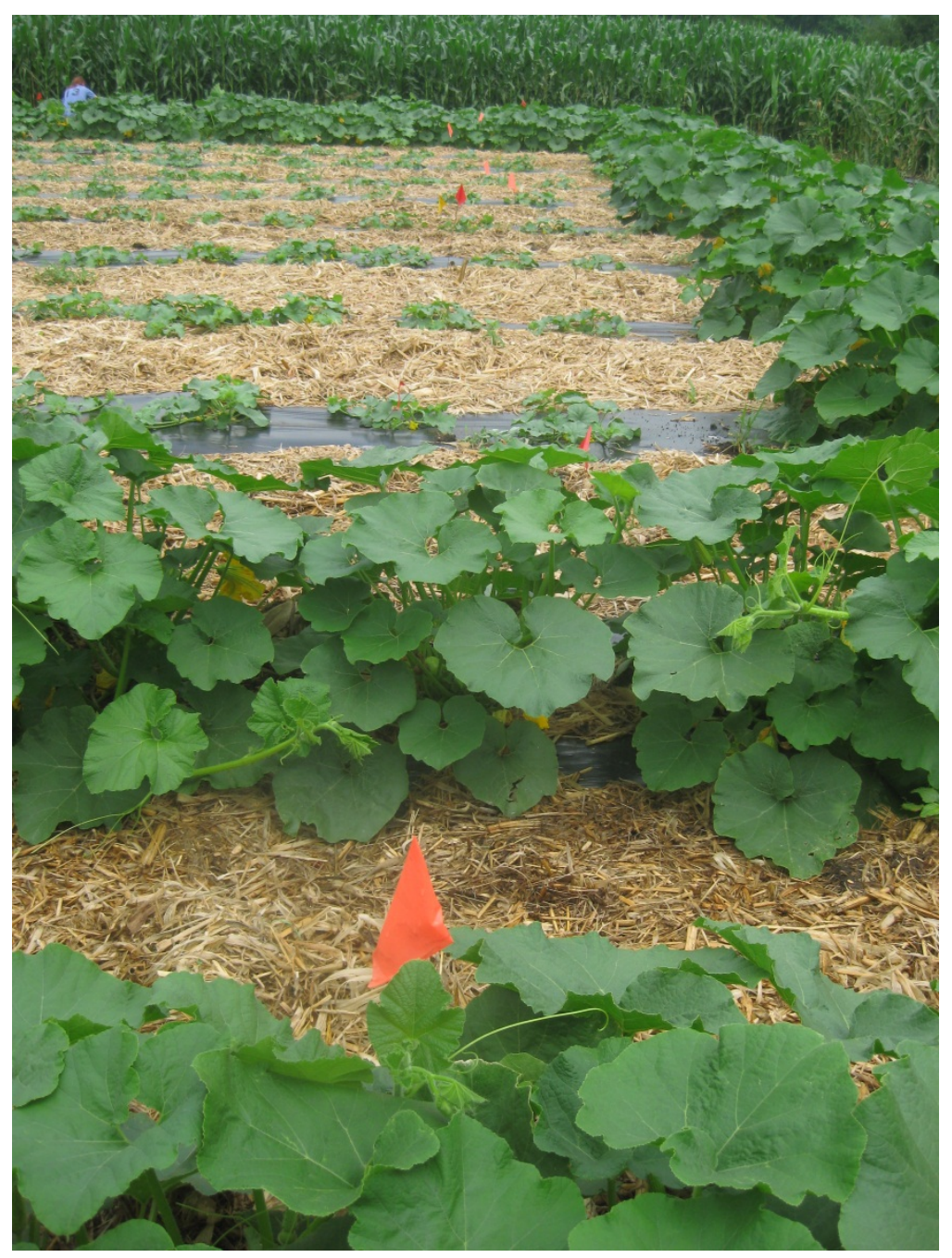

Figure 9. Perimeter trap crop system using ‘Buttercup’ squash around a muskmelon main crop. Photograph courtesy J.B Batzer. 


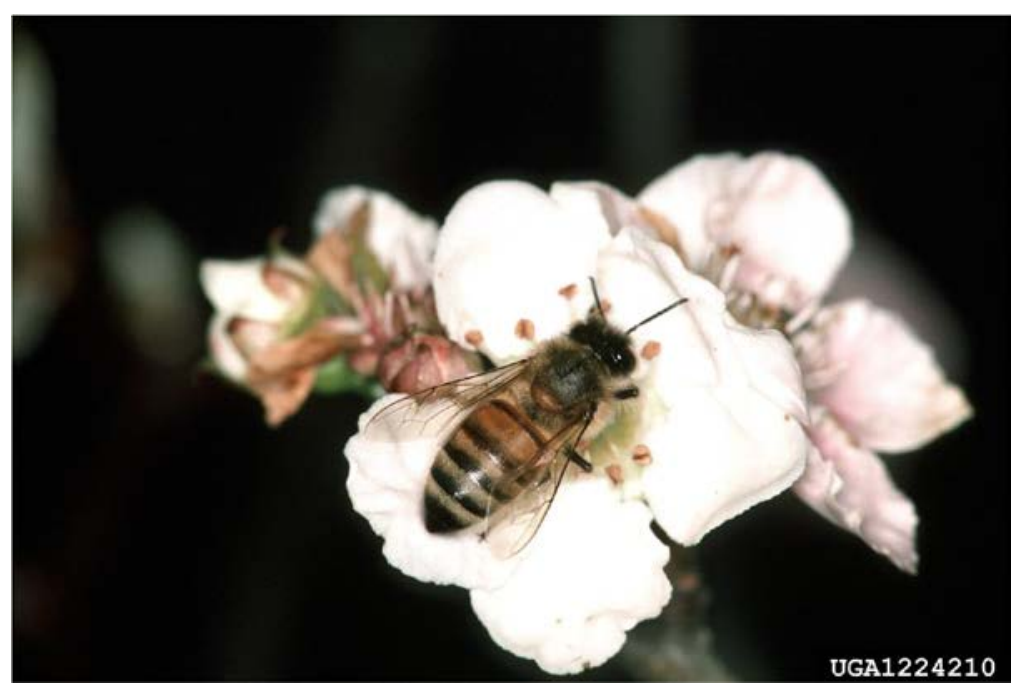

Figure 10. Honey bee (Apis mellifera). Photograph courtesy Jerry A. Payne, USDA Agricultural Research Service, Bugwood.org

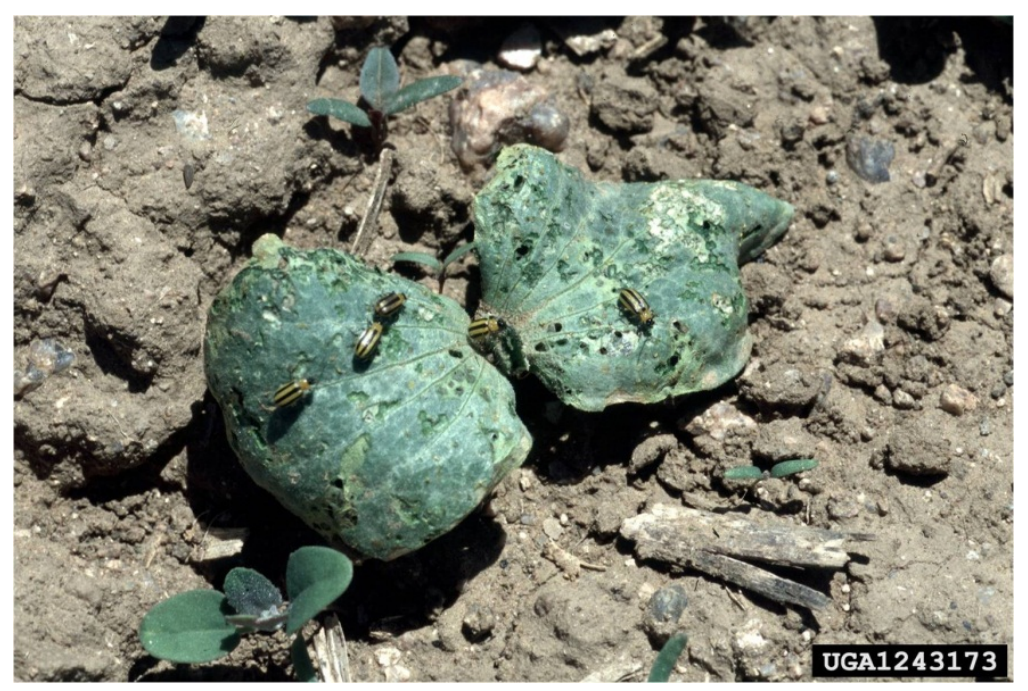

Figure 11. Striped cucumber beetles (Acalymma vittatum) feeding on a cucurbit seedling. Photograph courtesy Whitney Cranshaw, Colorado State University, Bugwood.org 


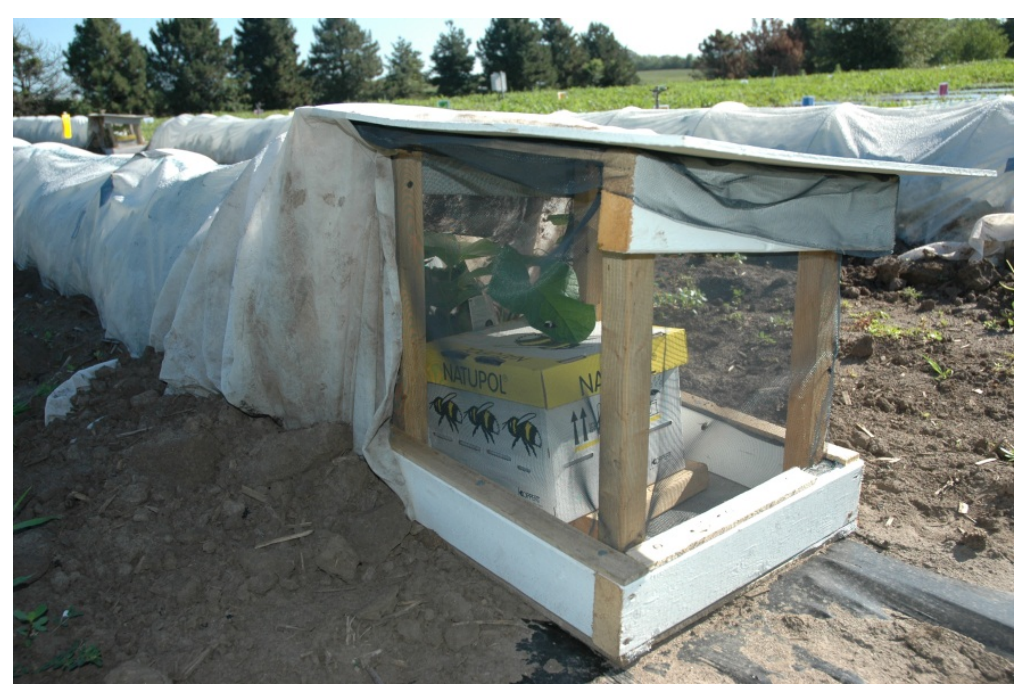

Figure 12. Bumble bee hives can be placed under row covers at anthesis to ensure pollination. Photograph courtesy J.B Batzer.

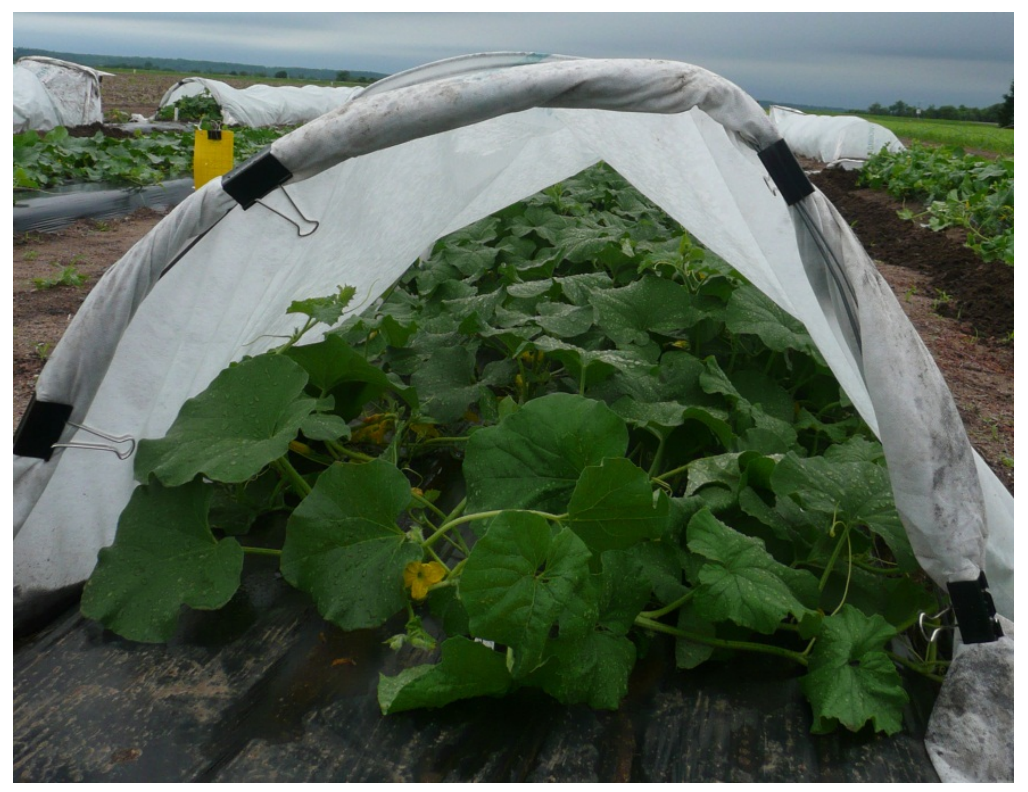

Figure 13. Row cover ends can be opened to allow access to natural pollinators. 


\section{CHAPTER 6}

\section{GENERAL CONCLUSIONS}

The overall goals of this research were to improve disease management of cucurbit bacterial wilt while advancing understanding of the ecology and genetic diversity of the pathogen, Erwinia tracheiphila. Specific research objectives assessed the use of row covers and delayed timing of row cover removal as a management strategy against bacterial wilt on muskmelon. As part of this objective, a partial budget was constructed to compare costs and returns of delayed removal to conventional row cover timing and no row covers. Our findings suggest that delayed row cover removal can significantly reduce the incidence of bacterial wilt, but that delayed planting conditions can negate the effect of delayed row cover removal. In the absence of disease, there was minimal difference in marketable yield among treatments, including the uncovered control. The economic analysis showed that delayed row cover removal strategies were profitable in the presence of disease, but reduced projected returns in site years where bacterial wilt was absent. A sensitivity analysis revealed that cost effectiveness of the delayed-removal strategy is likely to be impacted by the frequency of risk of bacterial wilt epidemics. The effectiveness of delayed row cover removal strategies may vary in different cucurbit cropping systems and cucumber beetle population densities. Future research should further validate this delayed row cover removal strategies in different geographic regions to provide better management guidelines for growers across the Midwest and Northeast U.S.A. 
Growth chamber experiments revealed that temperature and moisture conditions significantly impacted the survival of epiphytic populations of E. tracheiphila on muskmelon leaves. Under constant temperature and $100 \%$ relative humidity conditions, E. tracheiphila was able to survive up to 72 hours on leaf surfaces in the absence of frass. It was also demonstrated that fluctuating moisture conditions on leaves decreased E. tracheiphila survival. However, E. tracheiphila populations stabilized after two days, despite of continuously dry periods. Our study provided the first direct evidence that the vascular pathogen, E. tracheiphila, can survive on the surface of cucurbit leaves for several days. Surviving bacterial populations on plant surfaces can play a major role in disease development. This research has provided a first step toward determining the impact of epiphytic E. tracheiphila populations in the epidemiology of this pathosystem. Based on our results, we recommend that further investigations focus on clarifying the role of epiphytic E. tracheiphila populations as potential sources of inoculum under field conditions.

Furthermore, this research explored the genetic diversity of E. tracheiphila strains from different plant hosts and states within the U.S.A. Genomic DNA fingerprint profiles revealed two very distinct profiles generated by using rep-PCR techniques. The patterns easily distinguished Cucumis and Cucurbita strains associated with plant host origin. Pathogenicity assays further support the hypothesis that these patterns could reflect strain adaptations to particular plants hosts. Under growth chamber conditions, $E$. tracheiphila strains inoculated onto the same plant host from which the strain had been 
originally isolated caused plants to wilt significantly faster. In sum, our results provide the first evidence that strain specificity is associated with plant host.

Because it is critical to understand the impact of epidemiological and biological factors influencing disease development to develop management strategies, we feel that this research will have important implications in bacterial wilt management.

Finally, a case study describing a real life pest management situation was developed to enhance plant pathology concepts and promote problem solving skills in undergrad education. This educational resource features the cucurbit bacterial wilt pathosystem and the overall goal is to challenge undergraduate students studying plant pathology, horticulture, and entomology to design an integrated approach to manage an insect-transmitted disease in a commercial cucurbit cropping system. The case study was implemented at Iowa State University in two undergraduate level courses (Practical Plant Health and Fundamentals -PL P 391 of Entomology and Pest Management- ENT 376). Students and teaching assistants provided positive comments and constructive criticism that helped improve the case study, which will be available online for educators in numerous fields across the U.S.A. 